\title{
الأمل والتفاؤل محددان للصمود النفسى لعينة من طلبة الجامعة
}

\section{إعداد}

\author{
ا.دد/ ناديه اميل بنا \\ أستاذ بقسم علم النفس بادئ

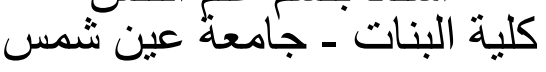

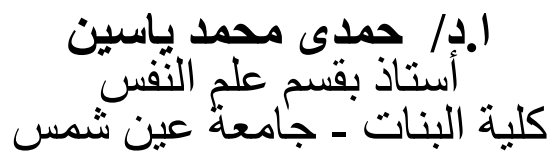

الباحثة / شيماء سيد أحمد على الفي

معيدة بقسم علم النفس سئ 


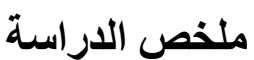

هدفت الدراسة تحليل العلاقة بين الصمود النفسى والأمل و التفاؤل لدى عينة من طلبة الجامعة ، و الكثف عن الفروق بين الذكور والأناث فى الصمود والأمل والتفاؤل ، وكذللك تباين كل من لن

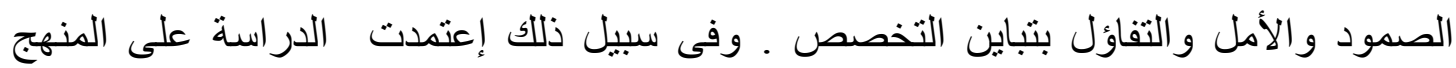
الوصفى الأرتباطى ؛ لكونه أكثر موائمة لتحقيق أهداف الدراسة من خلال الفنيات السيكومنرية التى تم تفصيلها بما يتناسب مع العينة فى ضوء المتغيرات الدختارة ، تضمنت عينة الدراسة (200) من طلبة الجامعة ( 100 = ذكور ) ، ( 100= أناث ) . وقد طبقت أدوات الدراسة : مقياس الصمود النفسى ، مقياس الأمل ، مقياس التفاؤل ، وأثنارت نتائج الدراسة إلى وجود علاقة بين الصمود النفسى ، وكل من الأمل و التفاؤل لدى عينة من طلبة الجامعة كما يختلف كل من الصمود و الأمل و التفاؤل بأختلاف المتغيرات الديموجرافية ( الجنس ) فى اتجاه الأناث (لفيل التخصص الدر اسى ) فى اتجاه التخصص العلىى. الكلمات المفتاحية : الصمود النفسى ، الأمل ، التفاؤل

\section{Hope and optimism are specific to the psychological resilience of a sample of university students.}

This study aimed to analyze the relationship between psychological resilience, hope and optimism among a sample of university students, and detect differences between males and females in resilience and hope and optimism, as well as every variation of resilience and hope and optimism to specialize. In order that the study relied on descriptive relational; for being more conducive to achieving its aims through psychometric technicians that have been customized to suit the sample selected variants, the sample included (200) of University students $(100=$ $\mathrm{m}),(100=$ female $)$. The results of the study showed that there is a relationship between psychological resilience, hope and optimism among a sample of university students, and resilience, hope and optimism of different demographic variables (gender) in the direction of females (Specialization) in the direction of scientific specialization.

Keywords: psychological resilience, hope, optimism.

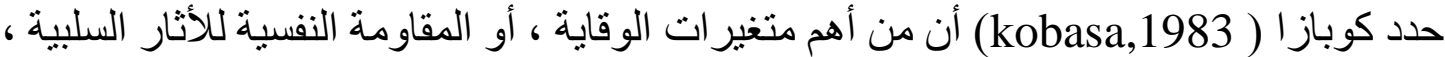

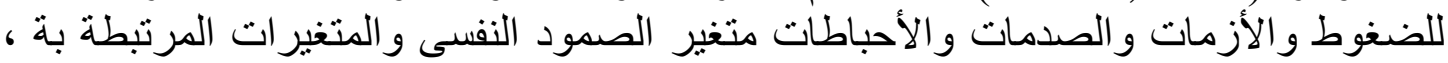


و أدت أسهامات (Garmzy\& Roter) إلى تحويل مسار البحث فى مجال الضغنوط إلى التركيز

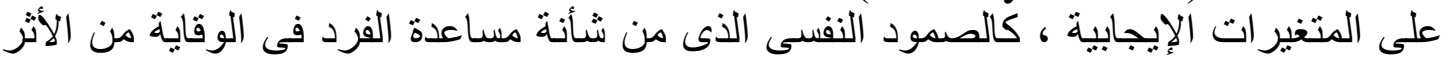

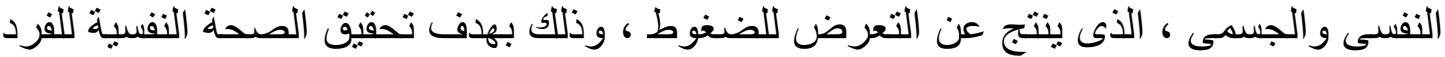

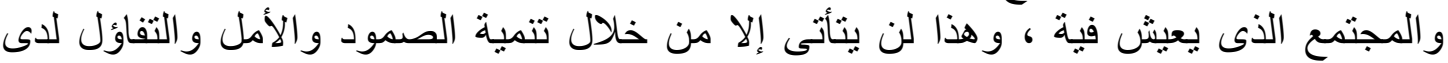

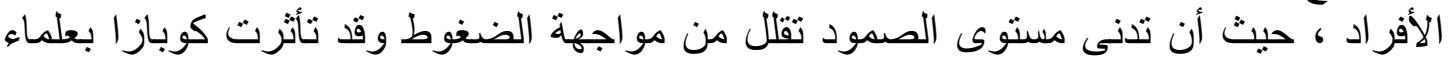

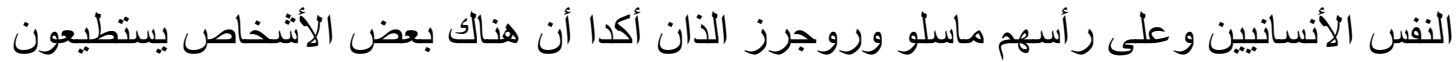

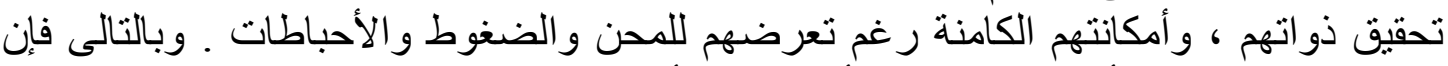
مجال الدراسة يجب أن بركز على الأشخاص الأسوياء ـ الذين يشعرون بقيمتهم ، ويحققون

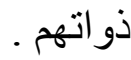

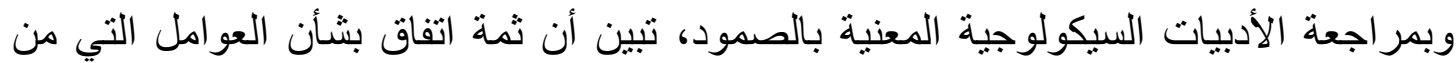

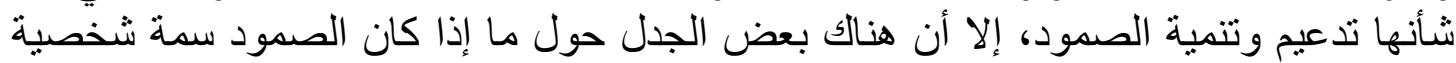

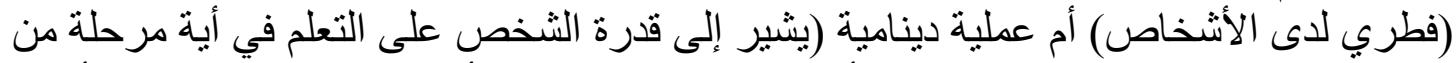

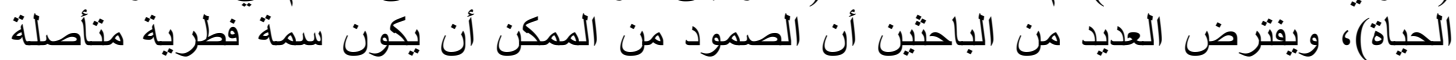

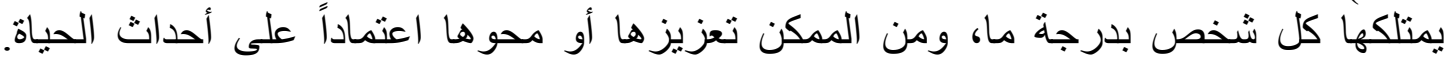

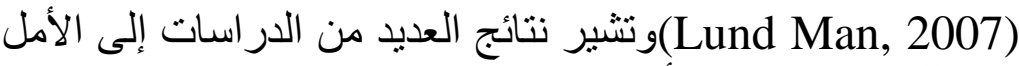

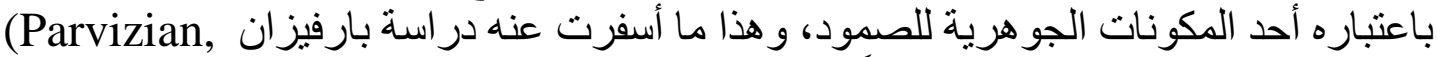

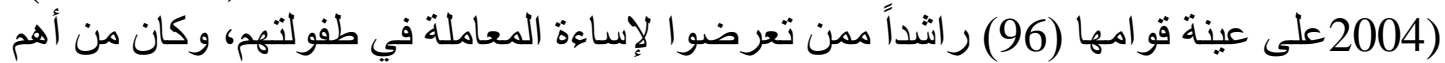

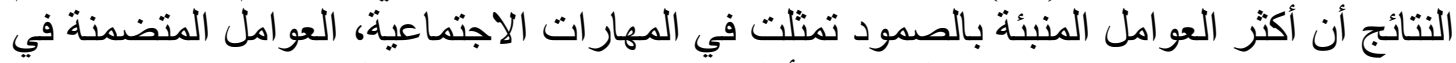

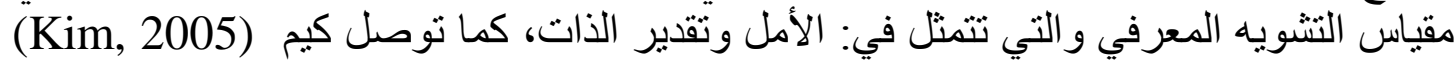

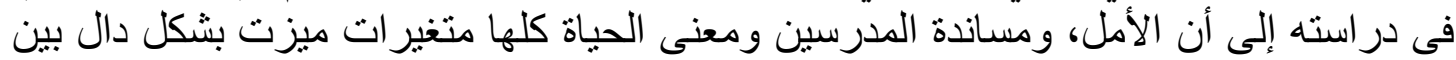
الطلبة الذين يتسمون بالصمود و أولئلك الذي يفتقدونه.

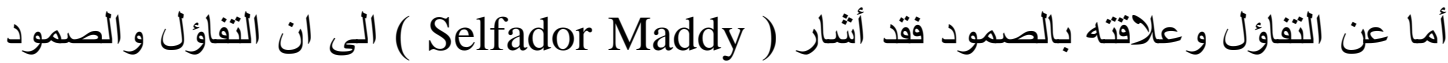

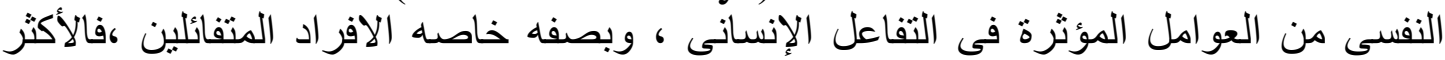

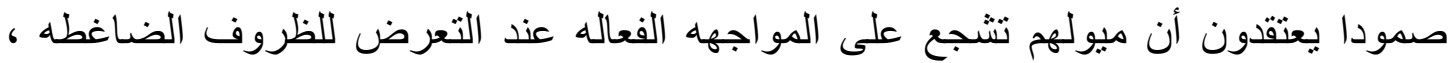

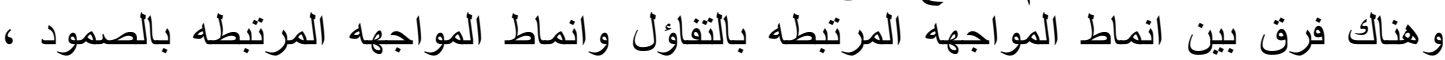

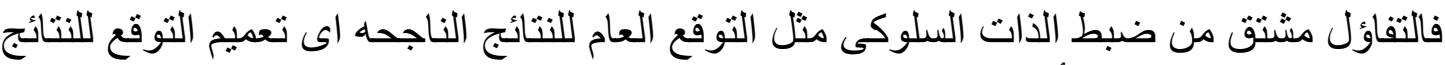

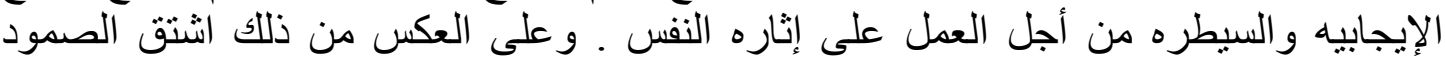

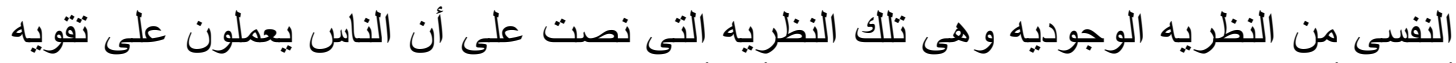

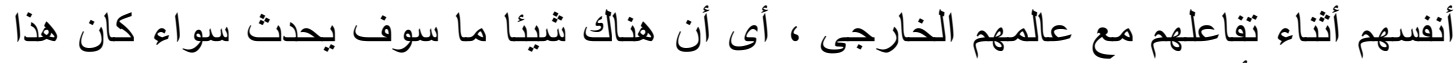

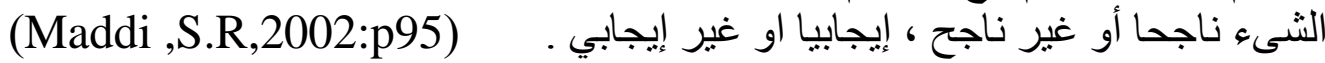

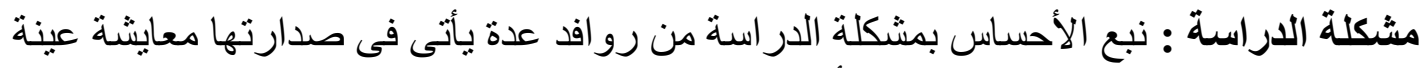

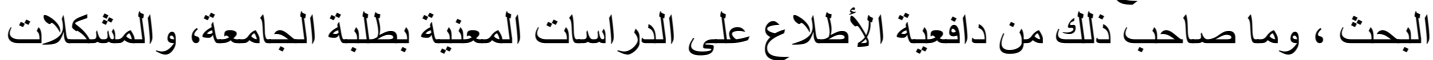

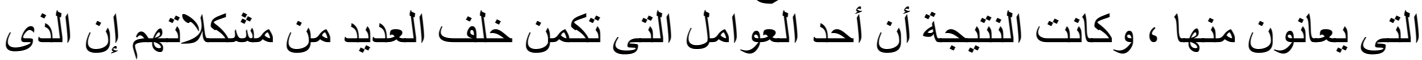

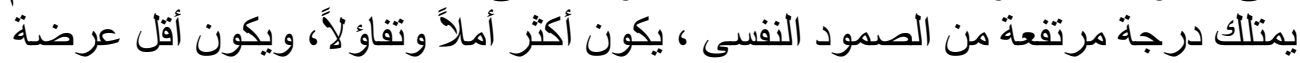

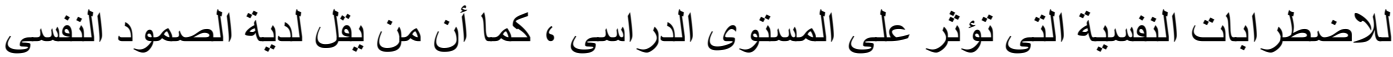

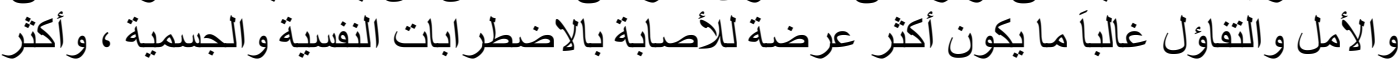
ضعفاً فى المقاومة و المواجهة

ويمكن تناول مشكلة الدراسة من خلال متغيراتها عبر المحورين التاليين : أولاً : الأمل والتفاؤل محددان للصمود النفسى : 
أسفرت دراسة (Kathleen, Puskar \& Sereika, 2007) على 624 من المر اهقين ممن

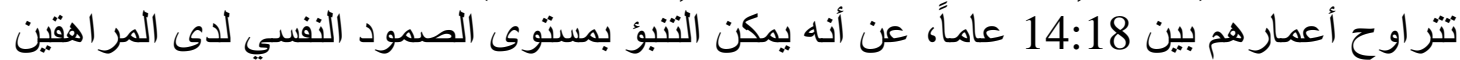

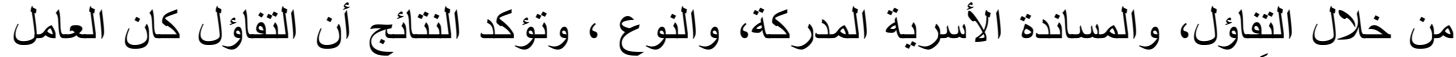

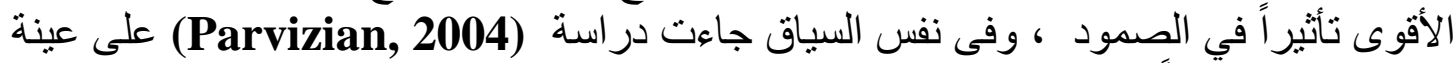

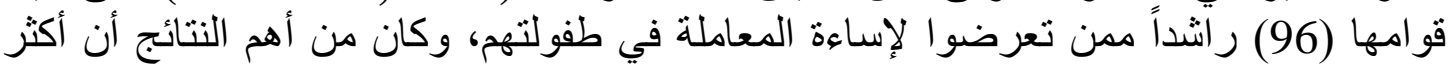

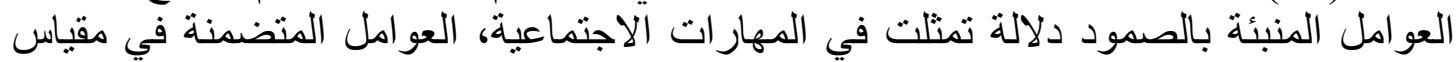

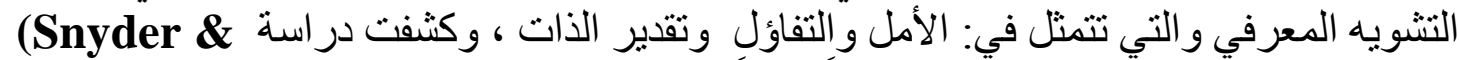

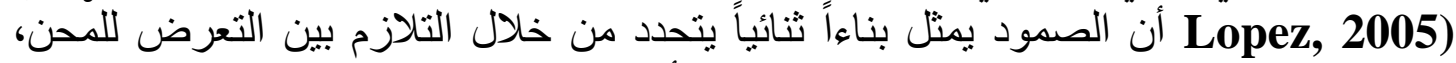

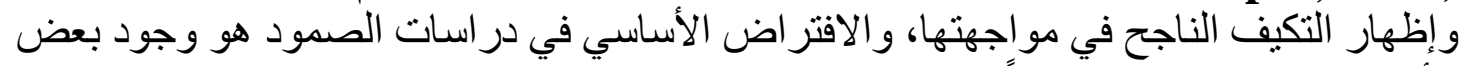

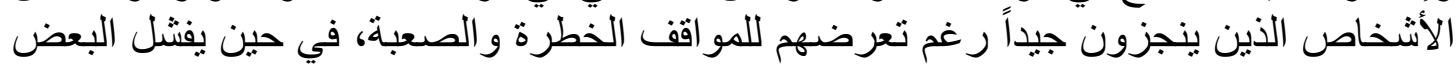

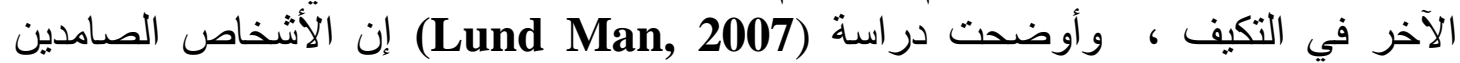

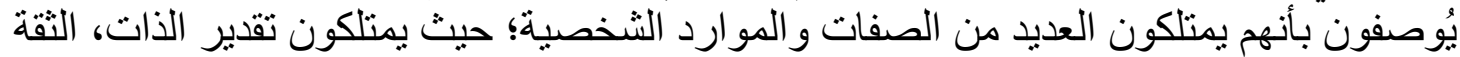

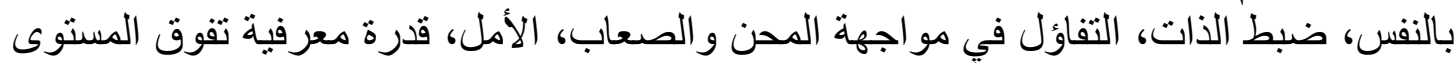

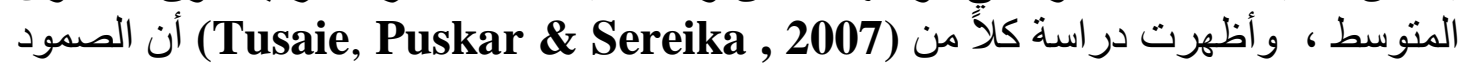

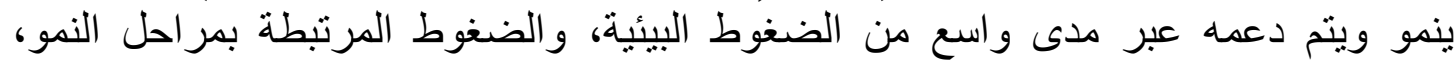

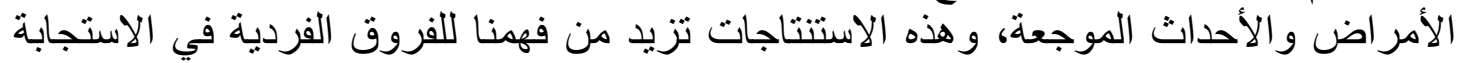

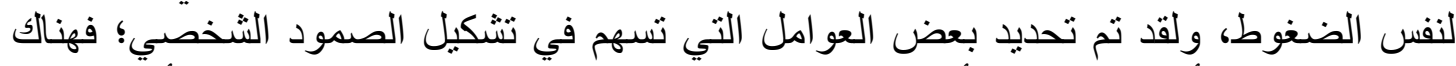

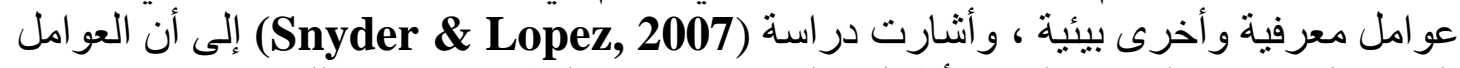

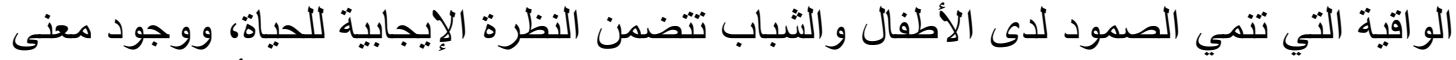

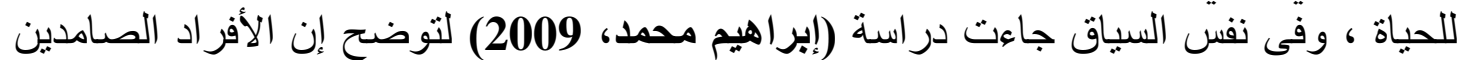

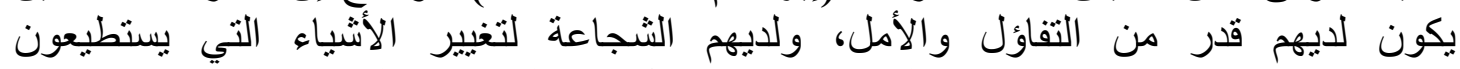

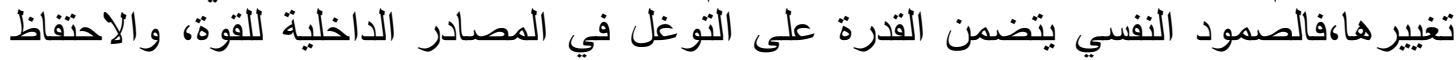

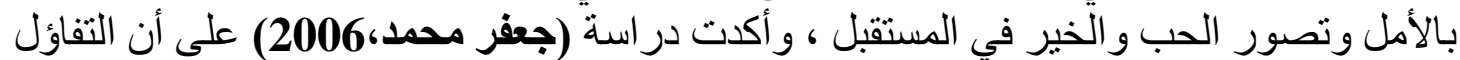

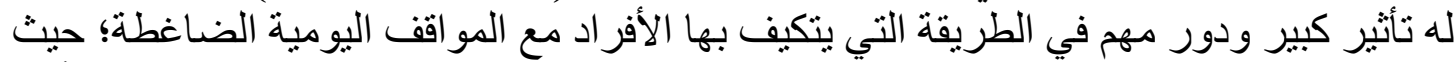

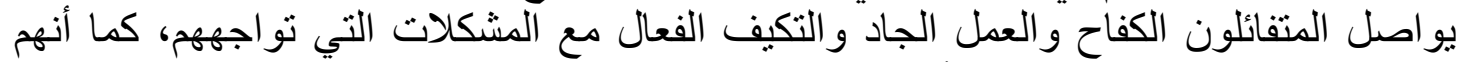

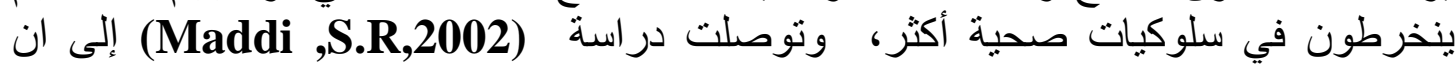

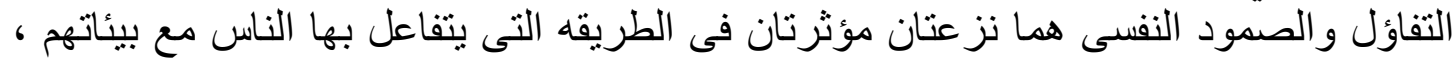

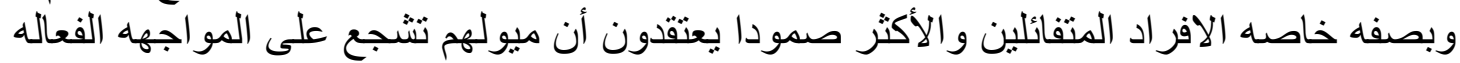

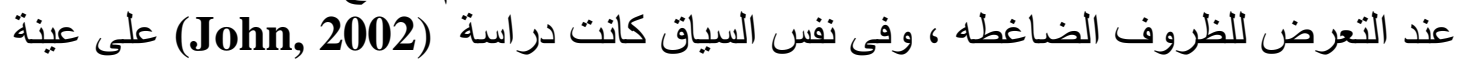

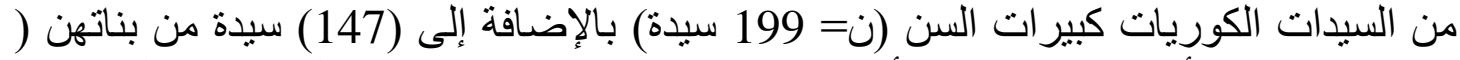

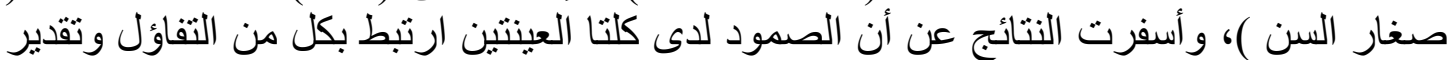

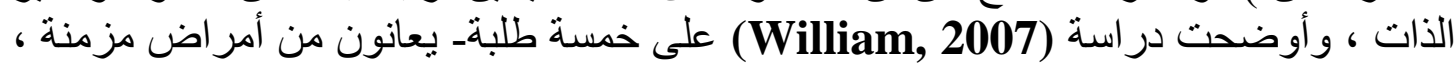

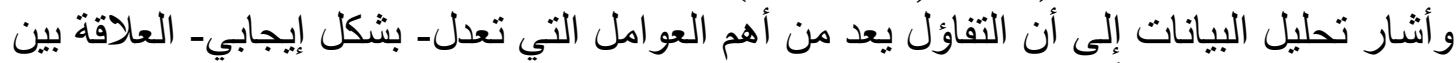

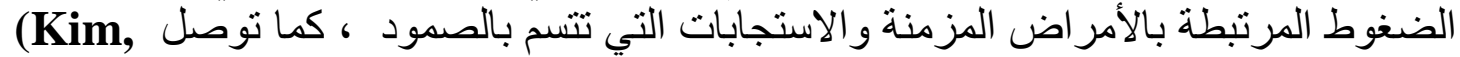

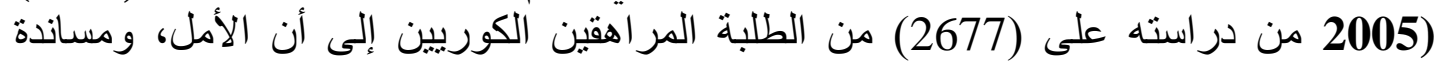

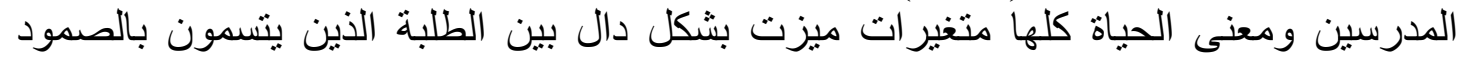

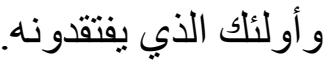
وفى ضوء ما تقدم نطرح السؤال التالى :

1 - ما مدى إسهام كل من الأمل والتفاؤل على التتبؤ بالصمود النفسى لاى طلبة الجامعة ؟

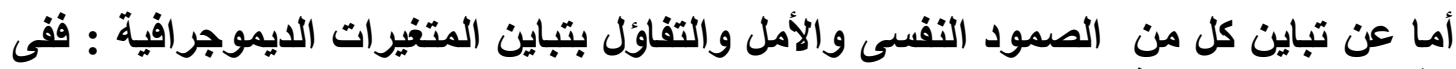

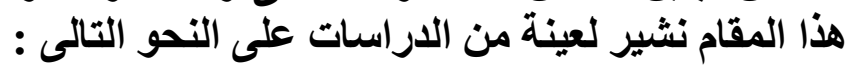


أ - الصمود النفسى والمتغيرات الايموجرافية : تشهد الأطر السيكولوجية بحضور قوي

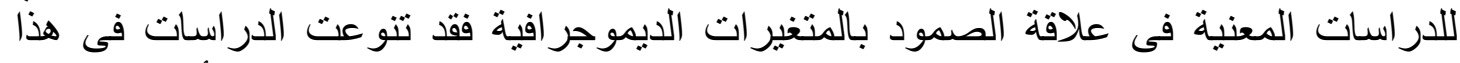

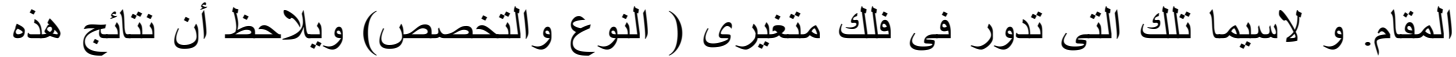

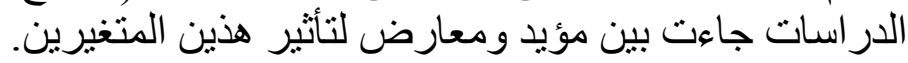

فعلى سبيل المثال نجد در اسات أثنارت لأرتفاع الصدود لدى الذكور كما فى الدر اسات الأتية : در اسة ( Mumford \& Rose, 2002 ) تنشير نتائجها الى إرتفاع الصمودالنفسى عند الذكور عنه عند الإناث ، وفى نفس السياق نجد در اسة(Copeland, 2006) و أسفرت النتائج عن أن أن

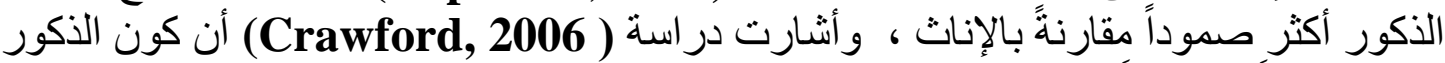

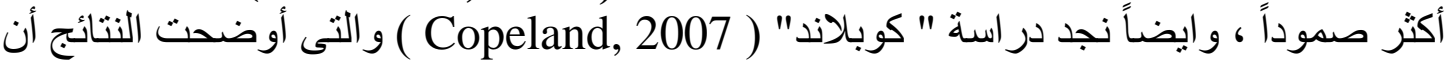

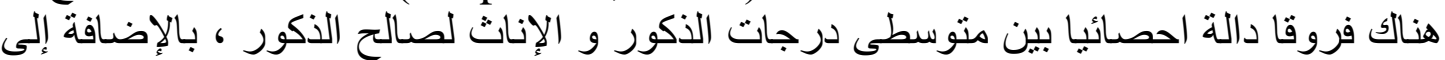

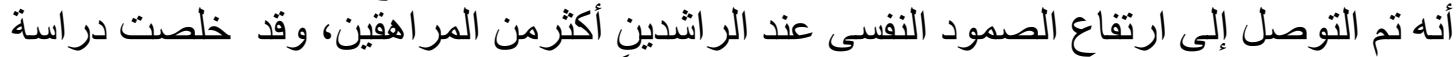

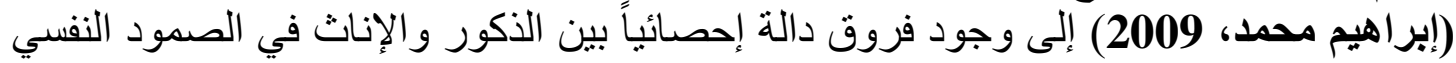

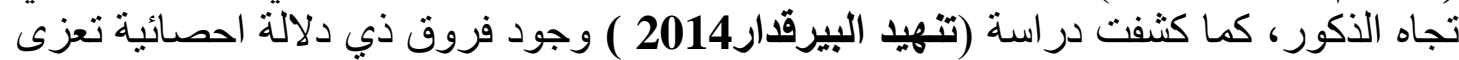

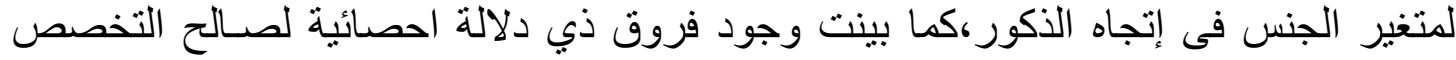
و على النقيض أشارت نتائج در اسات أخرى لأرتفاع الصمود لصالح الأناث كما فى در اسة كل

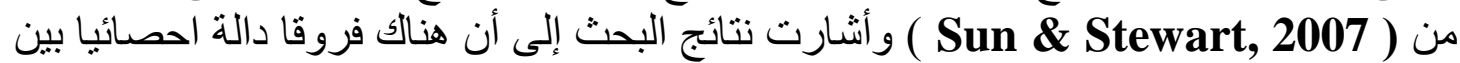

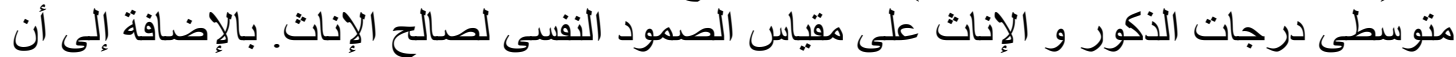

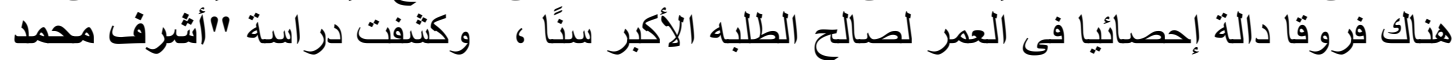

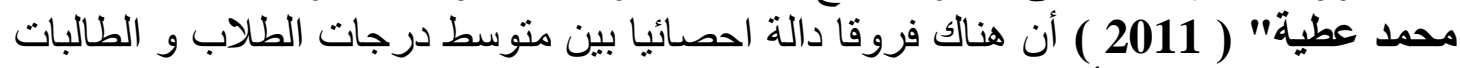

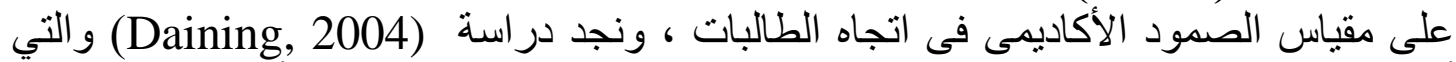

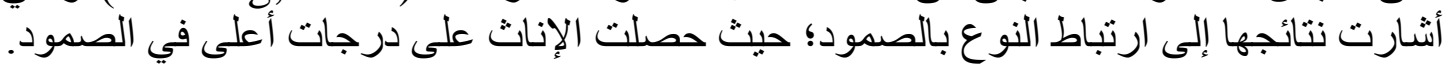

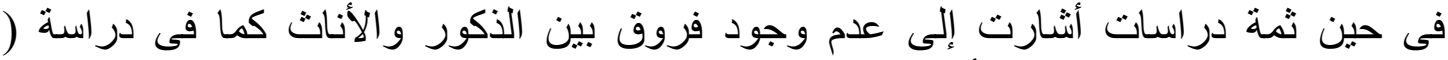
( Mistry et al. , 2009

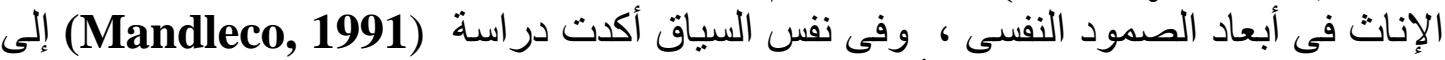

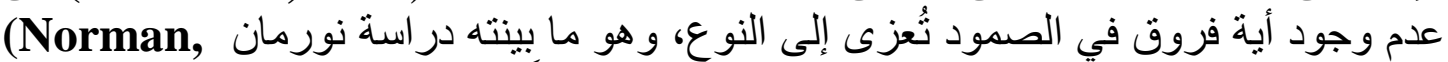

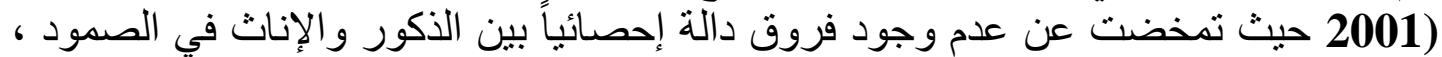

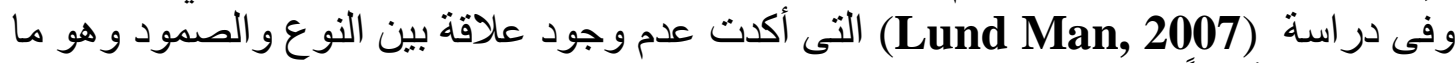
توصلت إليه أيضاً در اسة ويلز (Wells, 2007) .

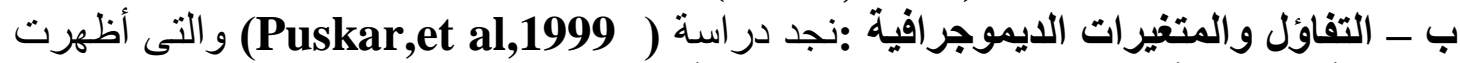

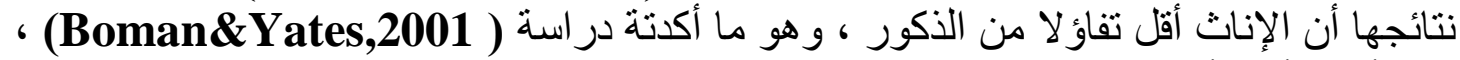

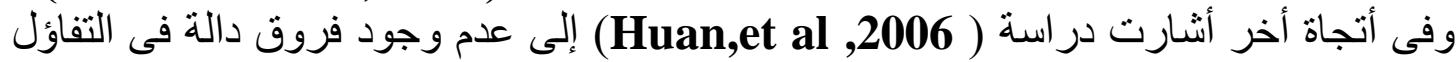

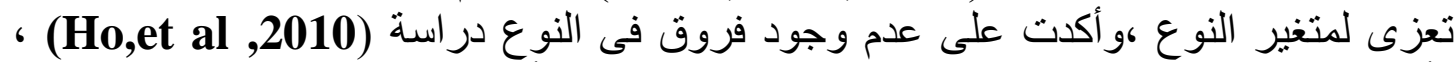

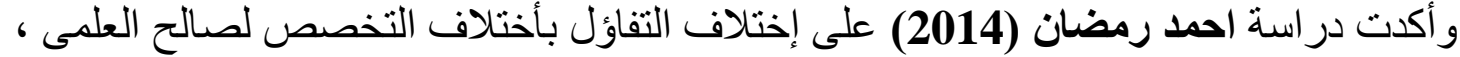

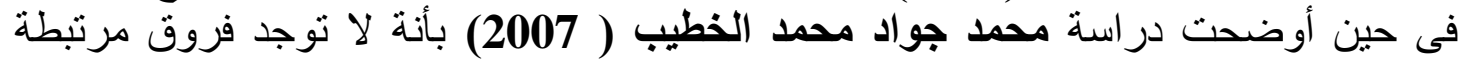

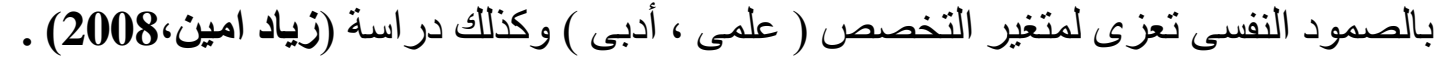

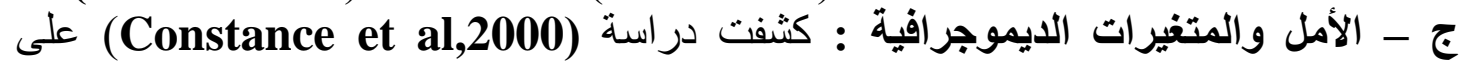

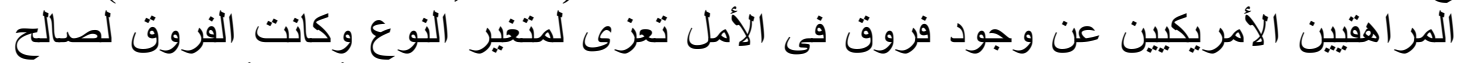
الإناث ، ودراسة ( Heaven\& Ciarrochi,2008) التى تناولت التيز الأمل و أساليب المعاملة

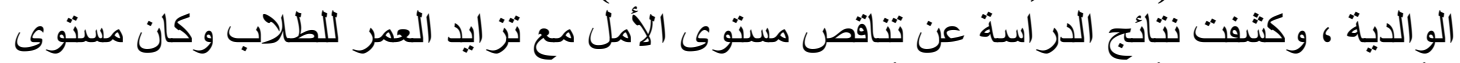

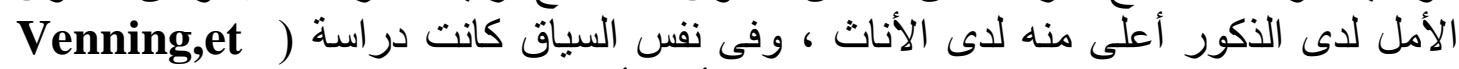

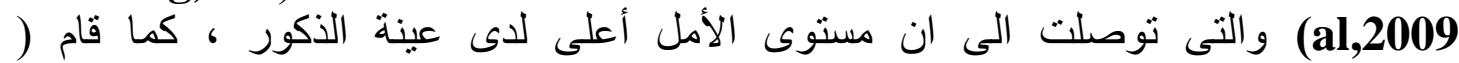




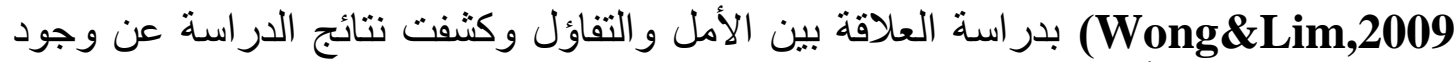

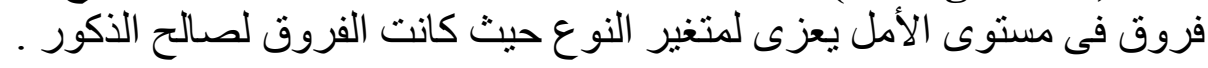

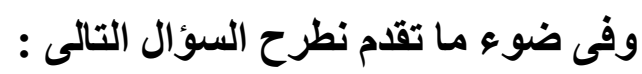

2- ما مدى تباين كل من الصمود والأمل و التفاؤل بتباين المتغيرات الديموجرافية ؟ أهداف الدراسة : فى ضوء ما سبق من أسئلة نصو غ الأهداف بصورة إجر ائية على النحو التالى 1 ـ تحديد إسهام كل من الأمل و التفاؤل فى التتبؤ بالصمود النفسى لطلبة الجامعة .

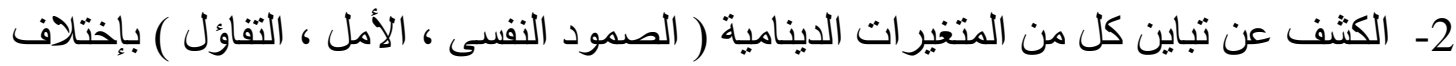

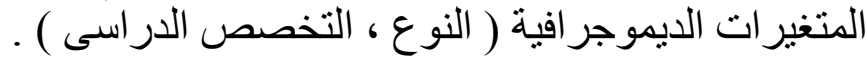

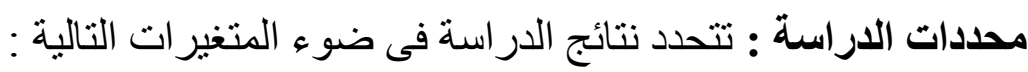

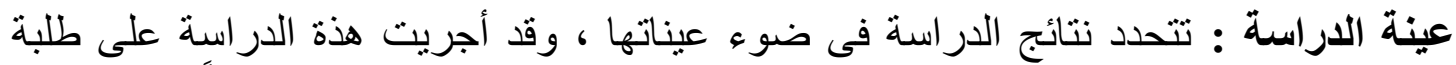

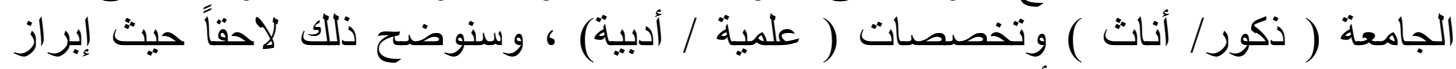
خصائص العينة ومبرر ات أختات أختيار ها .

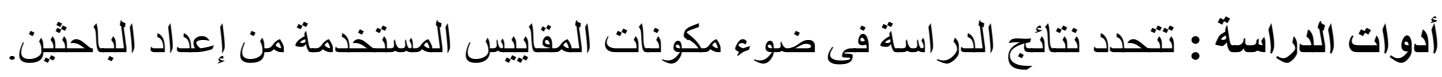

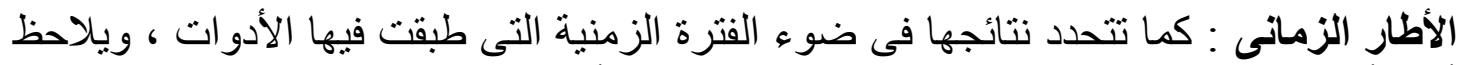

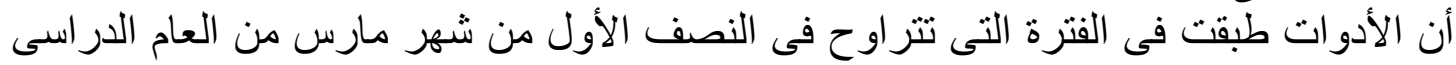
.2018/2017 الأطار المكانى : أختيرت عينة الدراسة من كلية البنات للأداب و العلوم و التربية ( كلية الأداب

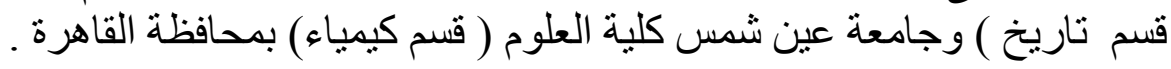
الأساليب الإحصائية : تتحدد فى ضوء أهاء أهداف الدراسة وحجم العينة ونوعية الأدوات المستخدمة

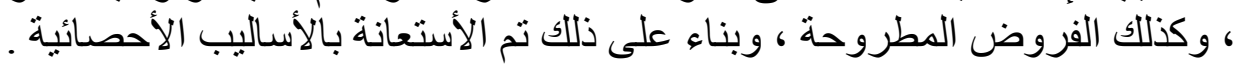

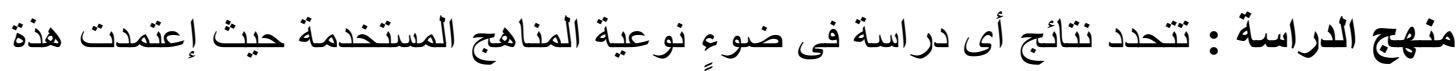

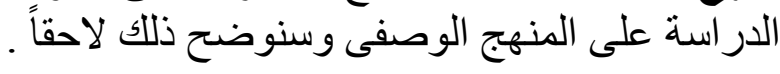

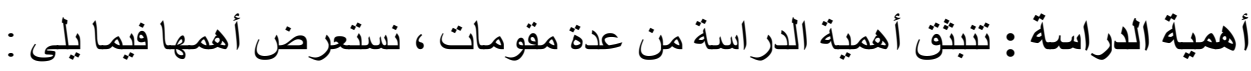

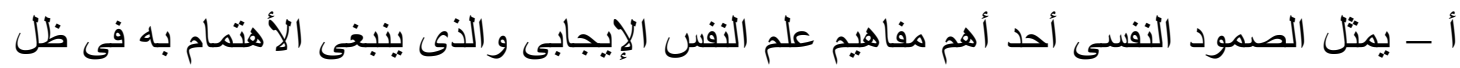

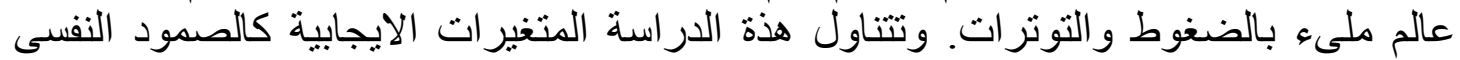

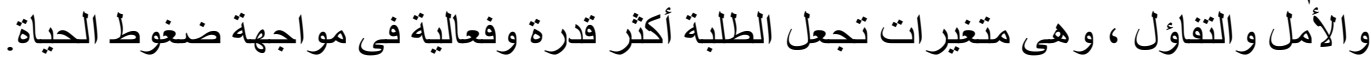

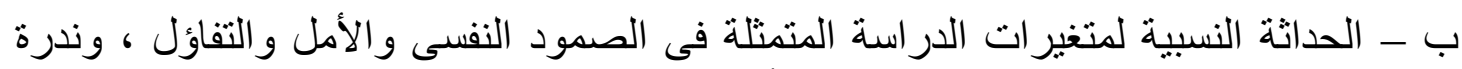
تناولها فى البحوث العربية مقارنة بالبحوث الأجنبية ، خاصة لدى الدية طلبة الجامعة .

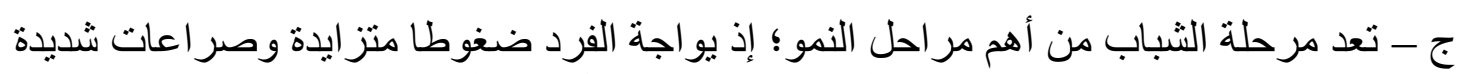

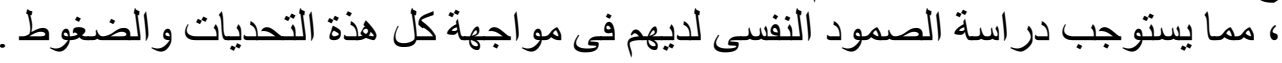

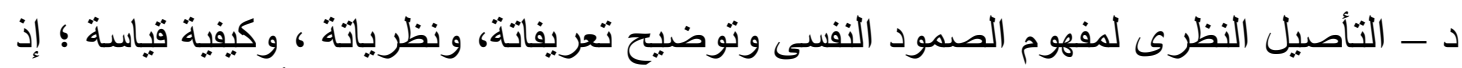

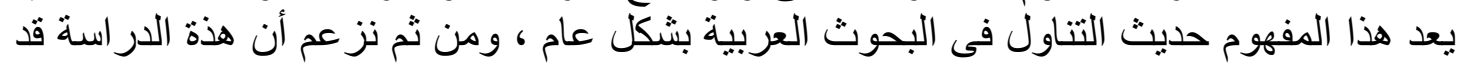

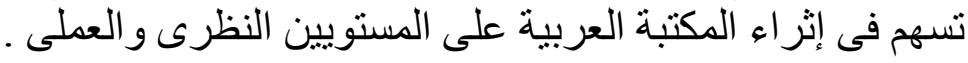


هـ ـ الإسهام فى إثراء المكتبة العربية للأختبارات و المقاييس النفسية من خلال إعدا الباحثين لمقاييس الصمود النقسى و الأمل و التفاؤل ؛ حيث تفتقر إلى إلى مثل هذا النوع من المقاييس

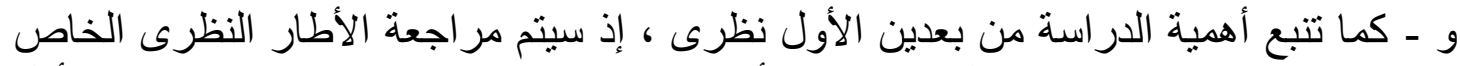

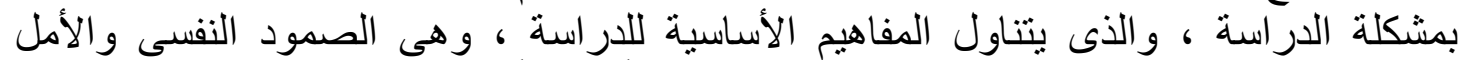

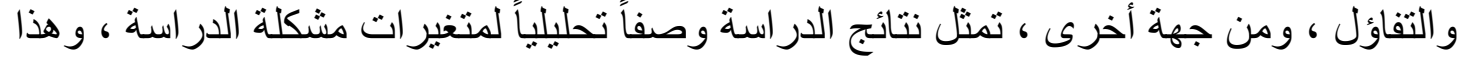
يثرى المكتبة العربية ، ويفتح المجال أمام در استات أخرى مستقبلية . التعريفات الإجرائية للمفاهيم الأساسية :

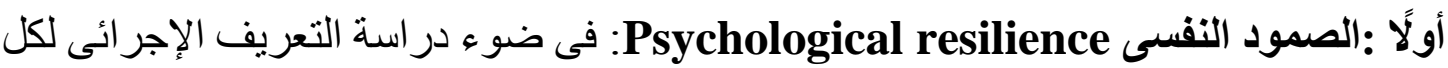

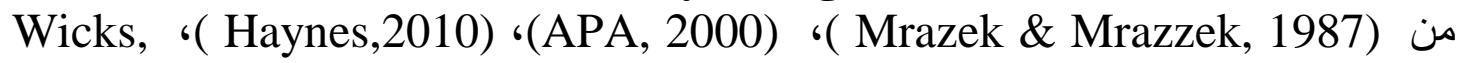
Benettie\& kambour ) ، ( Snap\&Miller, 2002) ، (Rutter, 1993 ) ،2005))

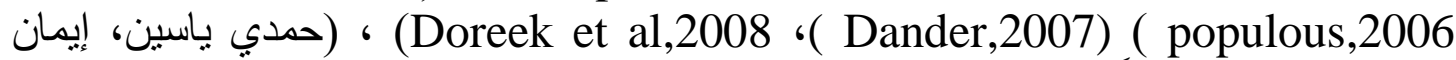

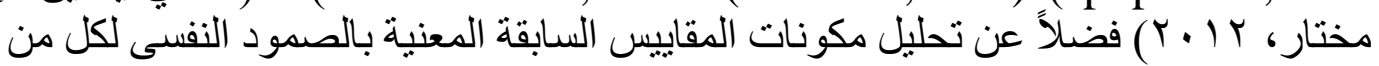

Noam\& Goldstein , ‘ (Block,J\& kremen,A.M,1996 ) ‘(conner , 1993) Hurtres \& ) ، (Vestal ,1997) ، (Block \& Kremen,1996 ) ، ( 1998

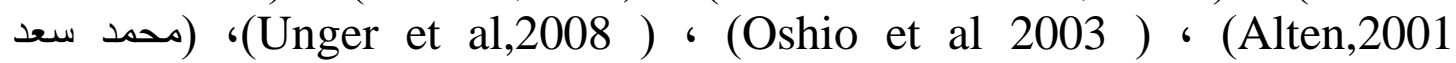

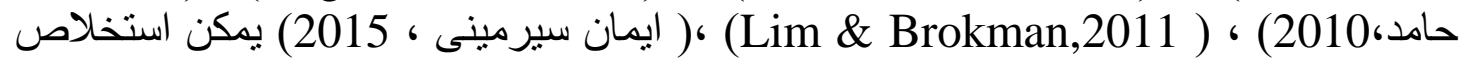

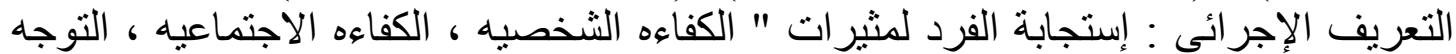

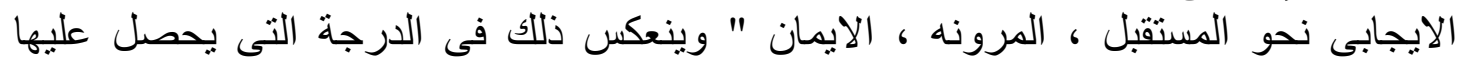
المفحوص على المقياس المعد لذلك ، المرنه ،

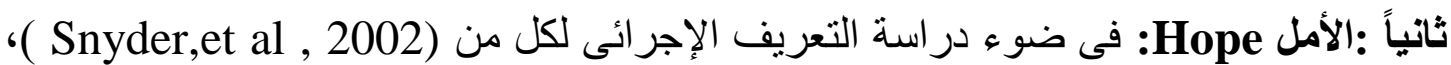
) ، (Heaven \&Clarrochi,2008 ) ، (Snyder et al ,2000 ) ، (Gottschalk,1985)

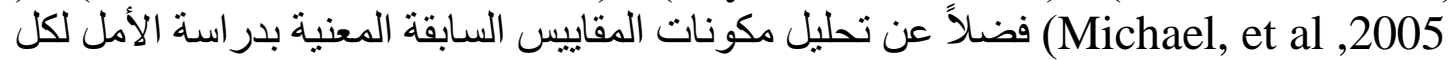

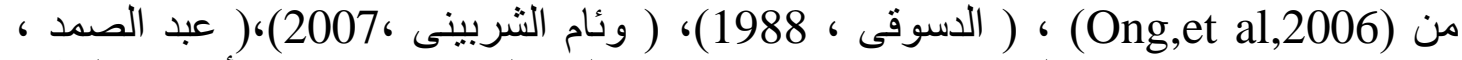

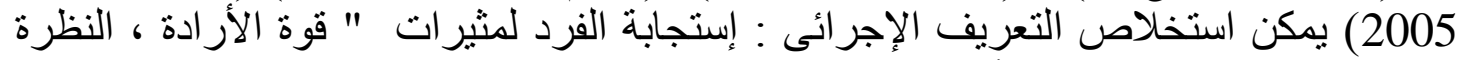

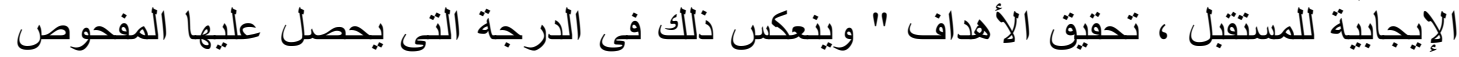

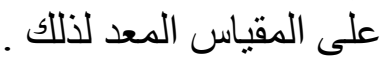

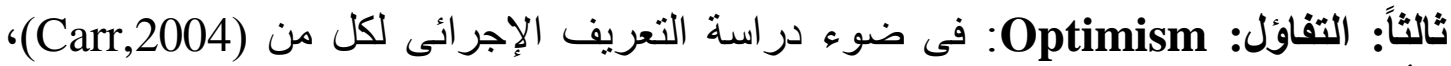

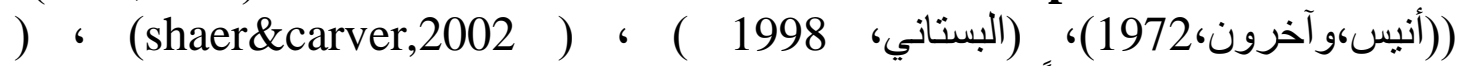

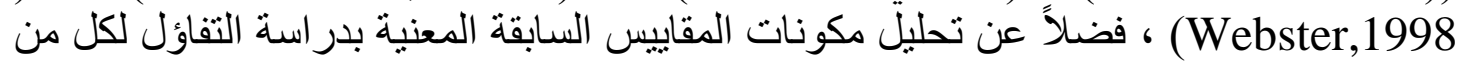

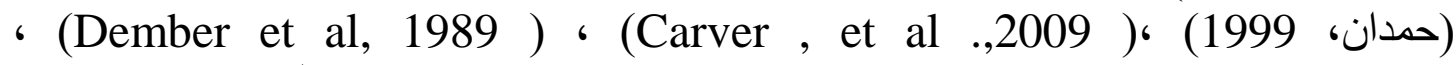

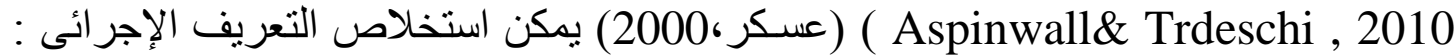

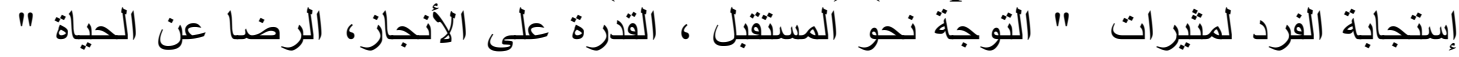

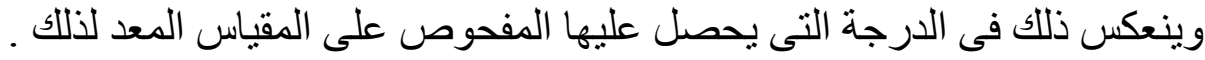

الأطار النظرى والدراسات السابقة : يتضمن الأطار النظرى متغيرات الاراسة على النحو التالى

1 الصمود النفسى :Psychological resilience:

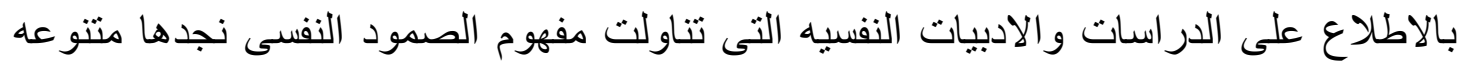

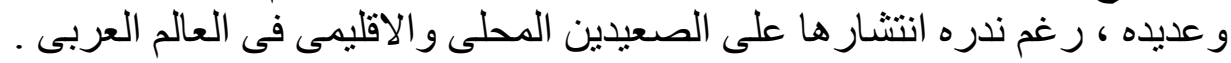


أ ـالصمود التفسى وبعض المفاهيم المتداخلة :

تستخدم مصطلحات مثل الكفاءه competence والمرونه والهاو

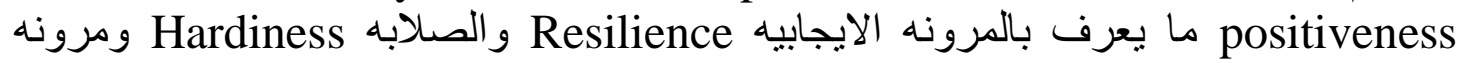
الذات Ego-Resilience - strength وقوه الذات

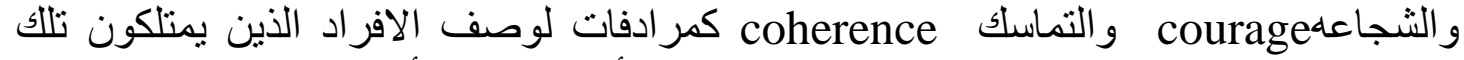

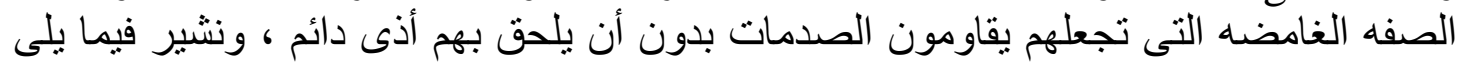

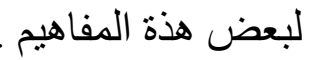

1- الكفاءه (competence) : الكفاءه هى ذلك المصطلح الذى يعبر عن أنواع متباينه من

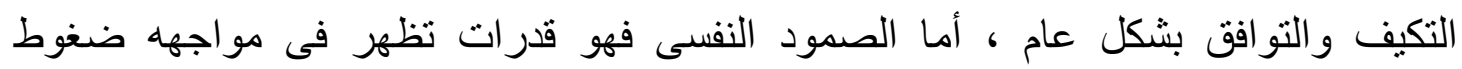

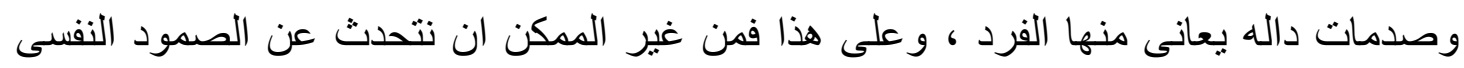
Rolf \&

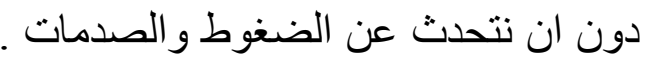

(Glantz,1999:7)

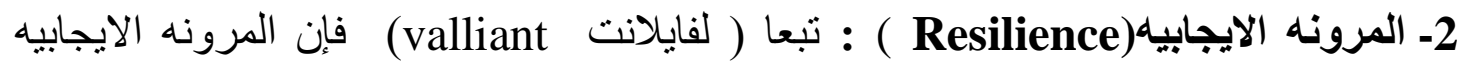

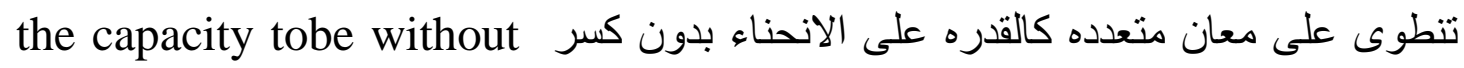

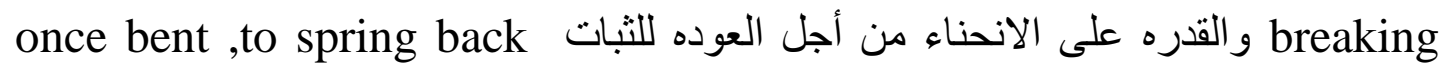

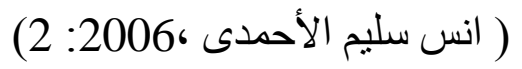
للصمود النفسى . 3 ـالصلابه النفسيه : (Hardiness):يعد مفهوم الصلابه النفسيه من المفاهيم شديده الصله

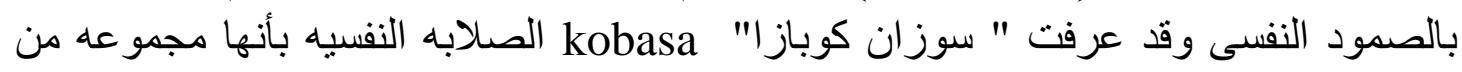

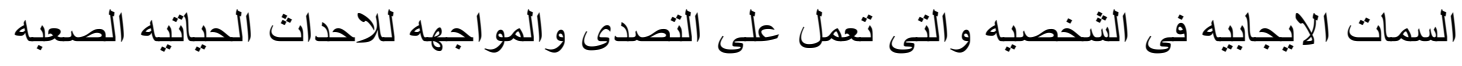

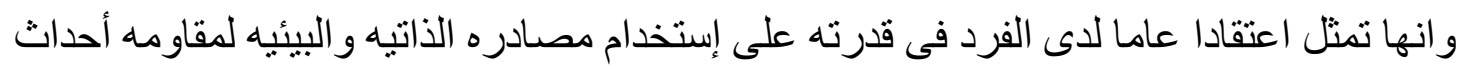

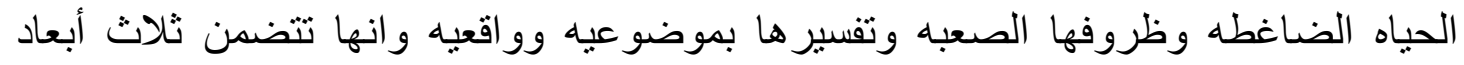
اساسيه ( الالتز ام ، و التحكم ،و التحدى).

4- الالتزام commitment:يعرف بأنه قدره الفرد على الالتزام بمبادئه وقيمه واولوياته فى هي

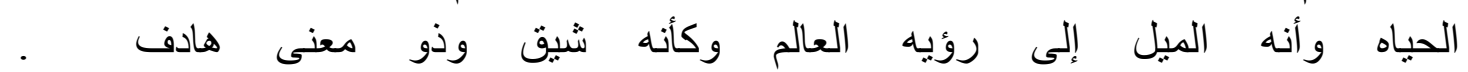
Barton ,p.t,2008,p10-11)

5- التحكم (control ) :ويعنى الاعتقاد بتوقع المو اقف الضاغطه ورؤيتها كمو اقف يمكن التغلب ( wiebe , D.j,1991,p89)

6-التحدى (challenge): ويعنى نوع من المثابره و المقاومه للمو اقف الصعبه فى الحياه ، وان الأفراد الأكثر تحدياً يرون الأحداث المتغيره و الخبرات الجديده وكأنها فرصه من من أجل Barton,p.t,2008,p10 )

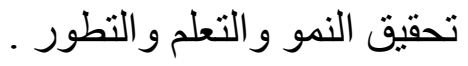

7ـ فاعليه الأات Self-efficacy: هو مفهوم يحمل معنى الثقه بالنفس ، و إدرالك قدره الفرد على التحكم و السيطره على الضغوط والاحداث الحياتيه الضاغطه ــ و يختص مفهوم فاعليه الذات

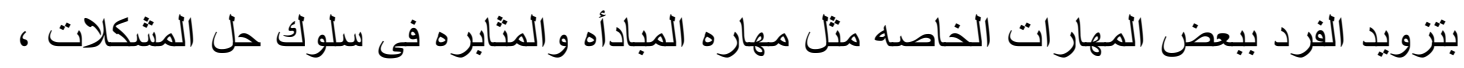

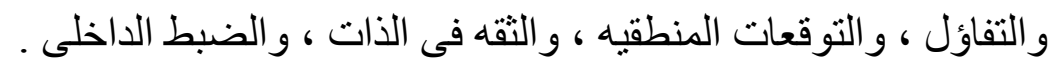


( أحمد على ابر اهيم ، عزت على سليمان ، 2003 : 153)

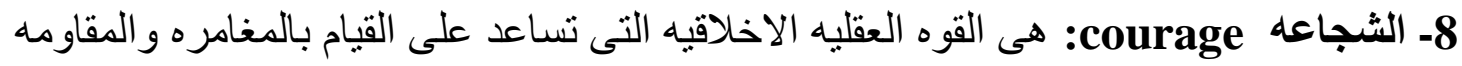

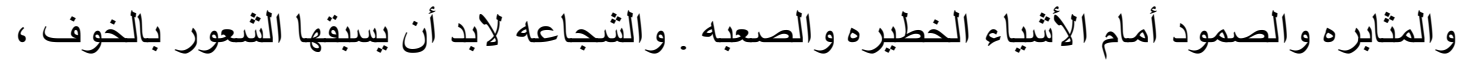

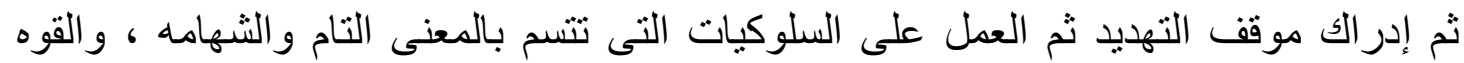
العقليه و الأخلاقيه

( عبداله محمد عبد النبى ،2012: 18)

9ـ التماسك : الإحساس بالتماسك هو المصدر الداخلى الذى يساعد الأفراد على التعامل مع : بلى

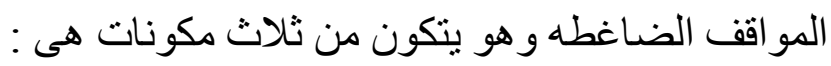

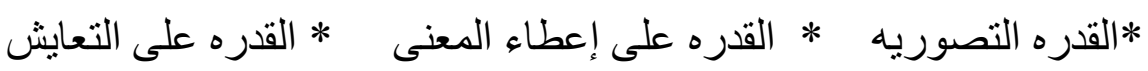

(Antonovsky, 1979,49)

ب - مكونات الصمود النفسى : تتعدد الأراء فى هذا المقام ومنها : تناول بروكش وجولاشتين ( Goldstien, Brooks,2004 ) مكونات الصمود النفسى: 1ـ التعاطف : ويمثل قدره الفرد على التعامل مع مشاعر و إتجاهات و أفكار الأخرين ، مما يسهل التو اصل و التعاون و الأحتر ام بين الأفر اد ـ التعاد

2 ـالتواصل : تعبير الفرد بوضوح عن أفكاره ومشاعره وأن يحدد أهدافه وقيمه الأساسيه ويحل المشكلات التى تواجهه . تعبئ.

3ـ التقبل : ويتمثل فى تقبل الفرد لذاته وللأخرين ، وذلك عن طريق أفتر اضات و أهداف و اقعيه

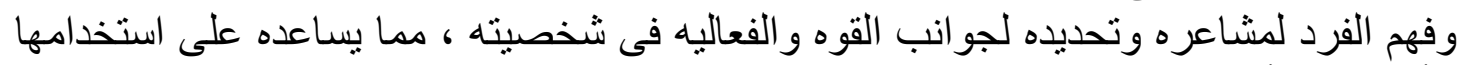

(Goldstien, Brooks,2004,p97 )

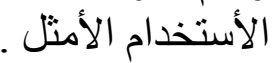

ج - سبل تنمية الصمود النفسى سلوك ، وكل سلوك يمكن قياسة ، وما يمكن قياسة يمكن

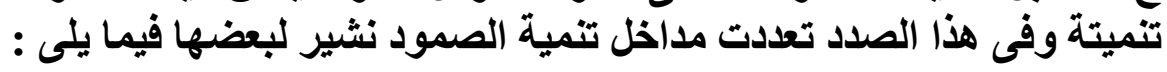
تحدد جمعيه علم النفس الامريكيه ( APA) عشره طرق لبناء الصمود النفسى : ا - إقامه روابط مكثفه مع الاخرين : تتمثل فى إقامه علاقات اجتماعيه مع أعضاء الأسره

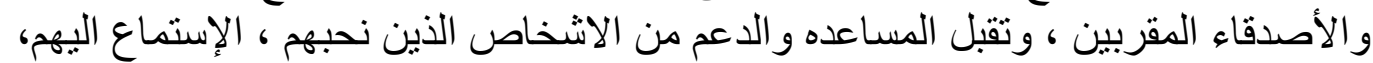

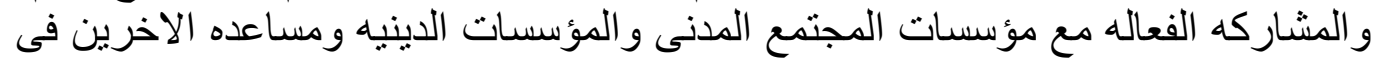

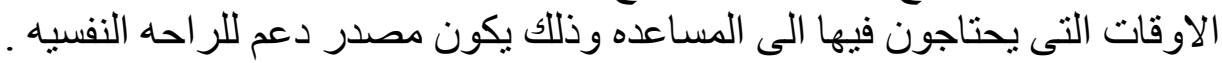

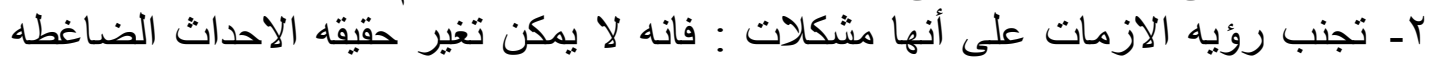

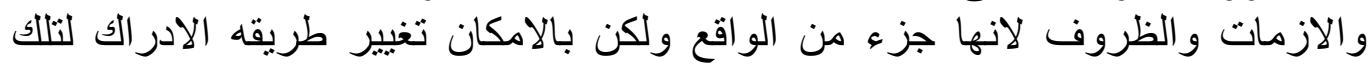

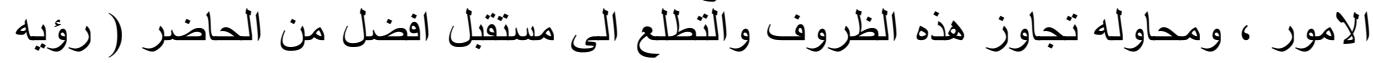
ايجابيه للمستقبل ).

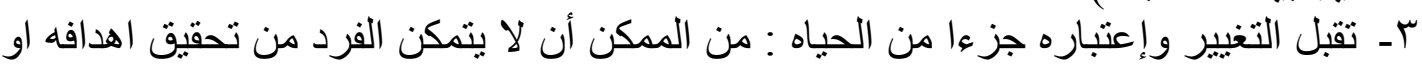

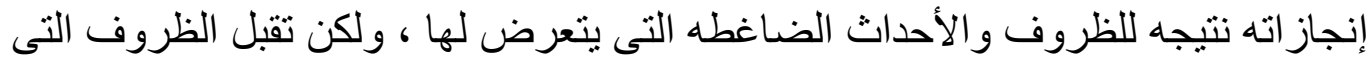

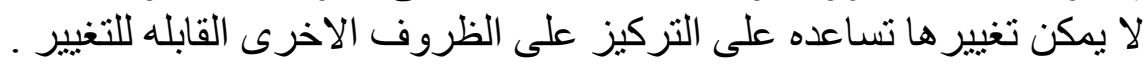


ع - التحرك تجاه أهدافك : ضع أهدافك واقعيه قابله للتحقيق فى ضوء إمكانياتك وقدر اتلك

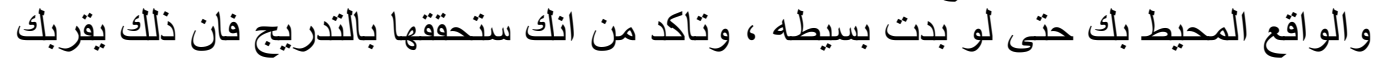

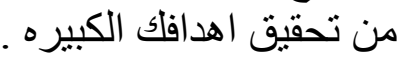
هـ إتخاذ قرارات حاسمه : تعامل مع الموقف الهبره الصعبه بأقصى ما تملكه من قوه ، واتخذ

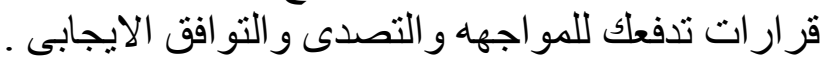

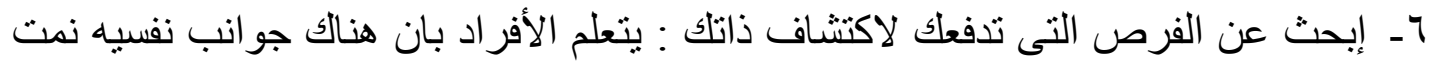

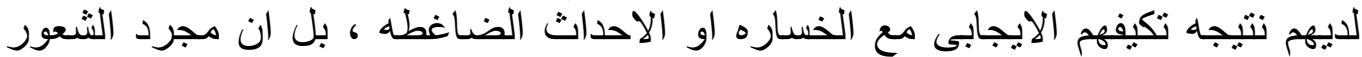

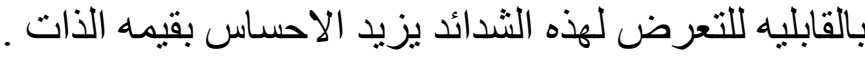

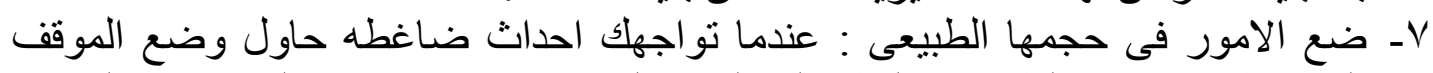

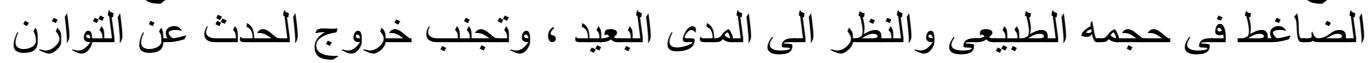

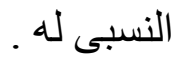
1ـ تبنى وجهاه نظر ايجابيه لذاتلك : ثق فى قدرثلك على حل المشكلات ، وثق فى ذاتلك تجد

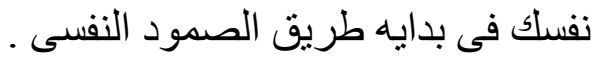

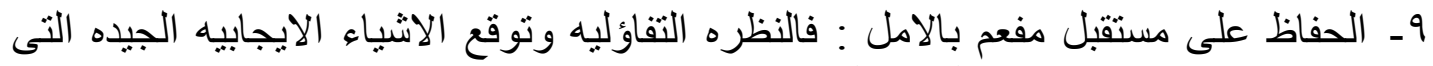

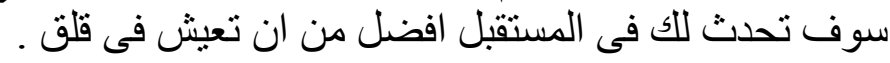

10 - إعتى بنفسك : إهتم وقدر حاجتلك ومشاعرك و اندمج فى الانتطه و الهوايات التى التى

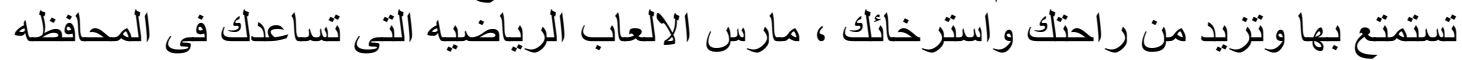

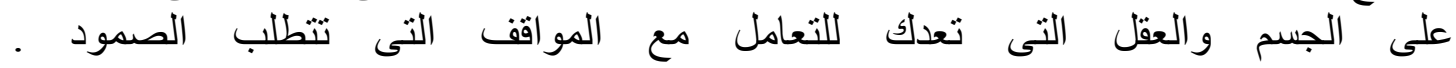
(APA, 2006,4)

والأمل والتفاؤل ( دراسات ميدانيه ) : وفى هذا الصدد نشير إلى بعض : الدر اسات فيما بلى : الصفى : الصفى توصل (kim 2005) من دراستة التى أجر اها على عينة من الطلبة إلى أن الأمل ومعنى الحياة

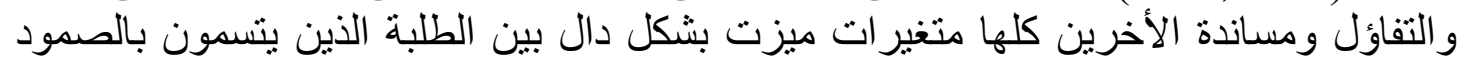

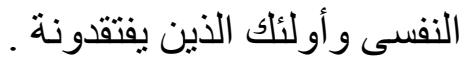

أما دراسة ( Collins, 2010 فقد هدفت دراستة بحث تأثثر الأمل فى العلاقة بين الخبرات

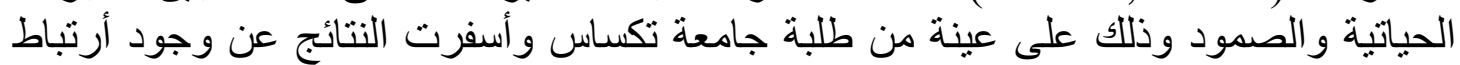
إيجابى بين الصمود و الأمل . كما هدفت دراسة جون (John, 2002) بحث الصدود لدى عينة من السيدات الكوريات

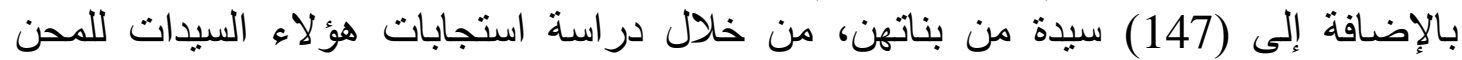

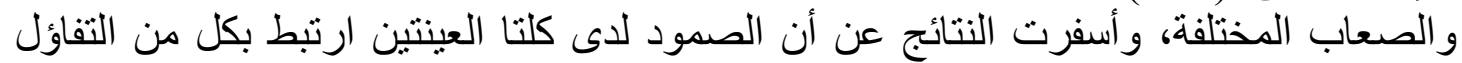
وتقدير الذات.

و عن دراسة ( Young, 2010 فقد هدفت بحث العلاقة بين الصمود النفسى و الأمل والتفاؤل

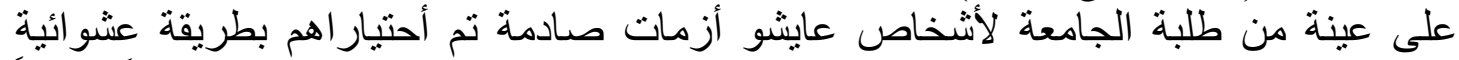

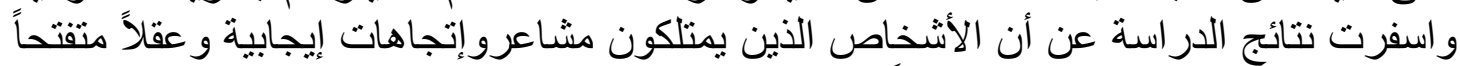

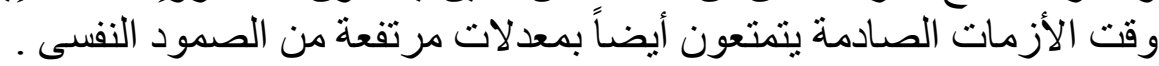

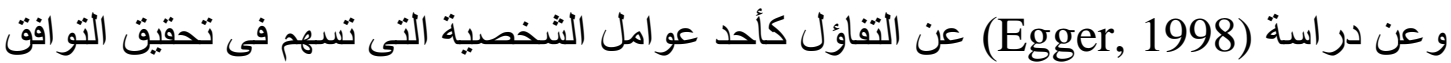
الإيجابى لدى عينة من الطلبة و الذين يتعرضون لئن لمستوى عالى من العنف ، و أثنارت النتائج إلى في

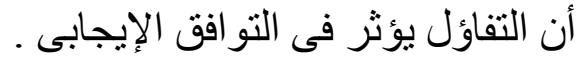




\section{أ - مفهوم الأمل والمفاهيم المتداخلة :}

يعتبر مفهوم الأمل من أهم الهفاهيم الأساسية فى علم النفس الإيجابى ، لما له من أثار إيجابية

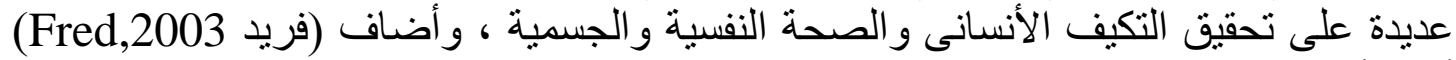

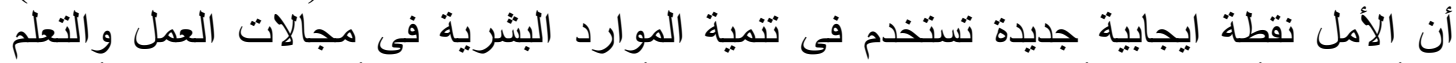

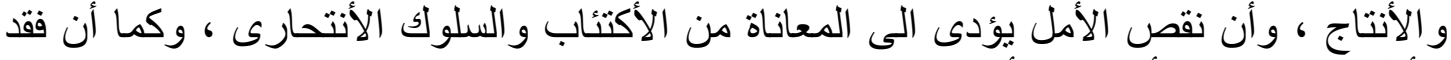

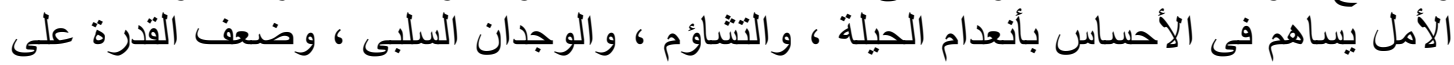
(عبد ) التحمل ، و التقييم السلبى للأحداث. الصمد ، 2005)

وقدم (سنايدر وزملاؤة 1991. Snyder et al) تعريفاً للأمل على أنة "حالة إيجابية تحفيزية

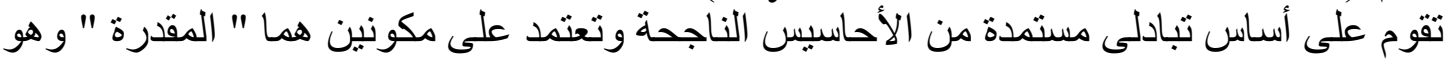

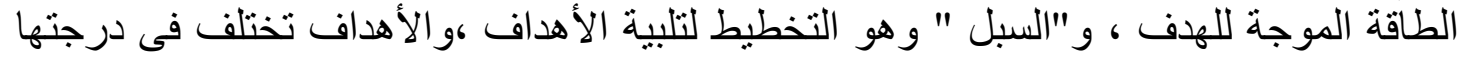

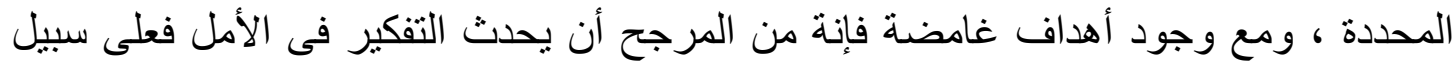

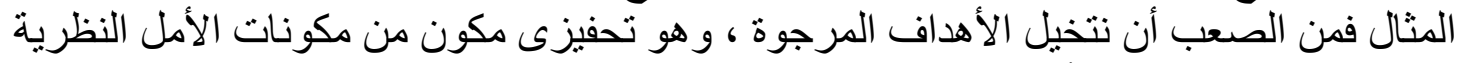

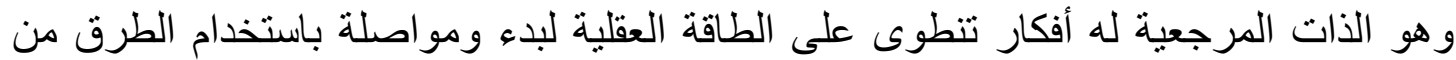

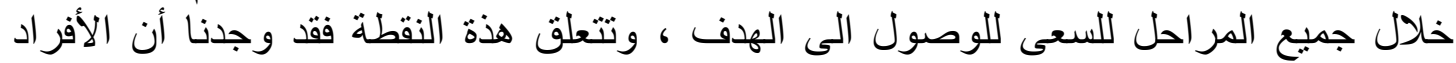

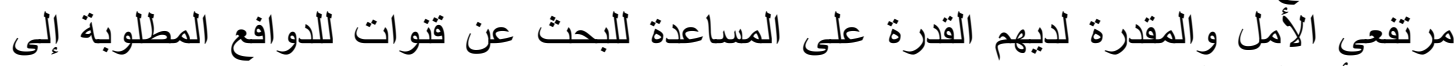
(Snyder,et al , 2002)

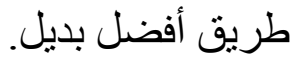
ب ـ مكونات الأمل : يرى سنايدر وزملاؤة (Snyder et al,2002) أن هناك مكونين رئيسين

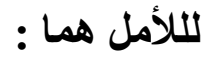

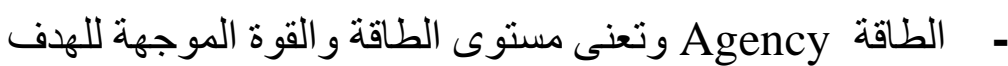

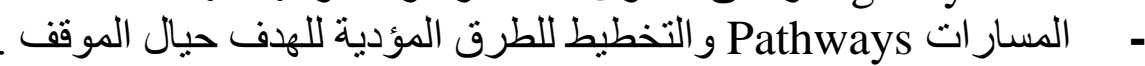

ج - النظريات النفسية المفسرة للأمل :

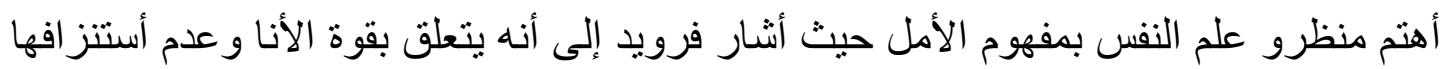

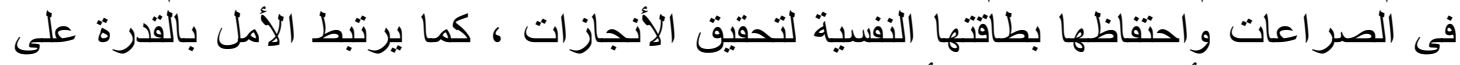

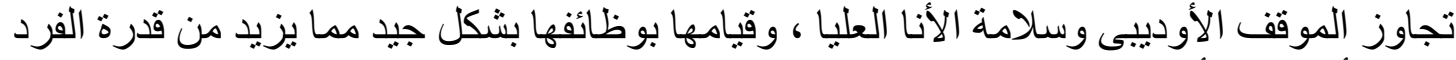

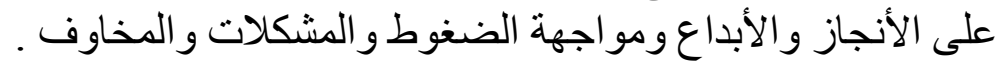

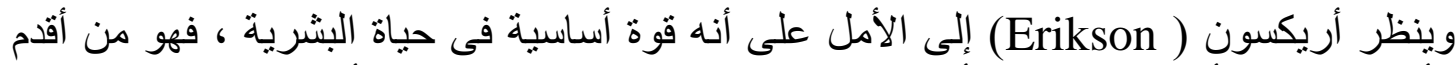

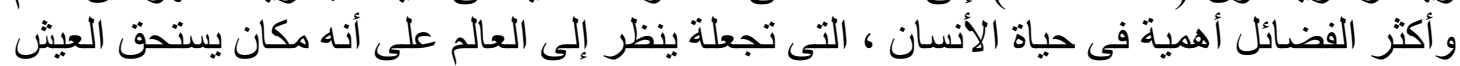

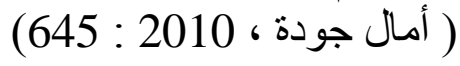

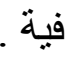
كذلك وضع أيفريل وأخرون ( Averill et al 1990) أربع قو اعد أساسية فى نظرية الأمل يعتقد أنها معاييرذات أهمية فى تصنيف الأشخاص حسب سمة الأمل : القاعدة الأولى : قاعدة العقل و التدبر وتثثير هذة القاعدة الى التوقعات المناسبة للفرد و التخمين

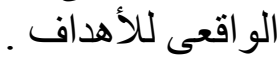

القاعدة الثانية : القاعدة الأخلاقية وتثير إلى مناسبة الأهداف للسياق الإجتماعى والأخلاقى و المعايير الثقافية .

القاعدة الثالثة : قاعدة الأولوية وتثير إلى القدرة على تحديد الأسبقية للأهداف وأسلوب العامل

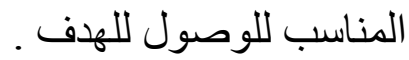


القاعدة الرابعة : قاعدة العمل وتشير إلى الأستعداد لأنجاز الأهداف بطرق مناسبة و لائقة. (95:2008 ، ( عبد المحسن دغيم )

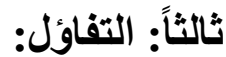
أ - مفهوم التفاؤل و بعض المفاهيم المتداخلة :

على الرغم من أهمية التفاؤل فى الحياة الأنسانية بشكل عام ، وفى الدر اسات النفسية بشكل خاص

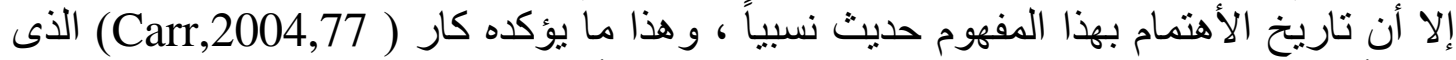

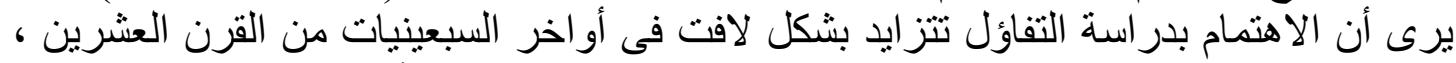

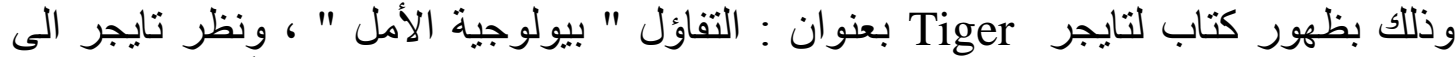

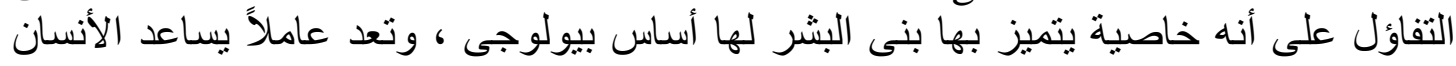
على البقاء ، ويمكنة من التغلب على الصعوبات و المحن التى قد تو اجهه فى الحياة من خلال اعتقاده بأن الأشياء ستصبح أفضل في المن المستقبل .

(عو اطف إبر اهيم أحمد شوكت ، 2002، 203)

ب - النظريات النفسية المفسره للتفاؤل:

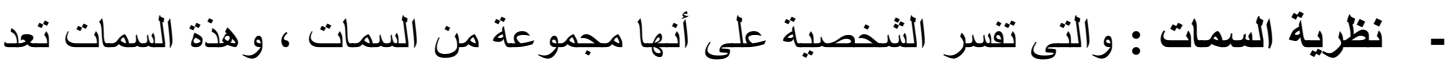

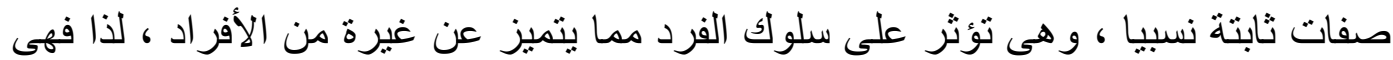

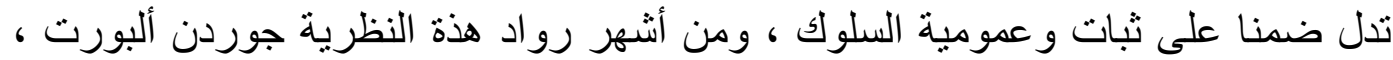

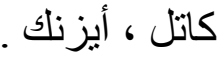

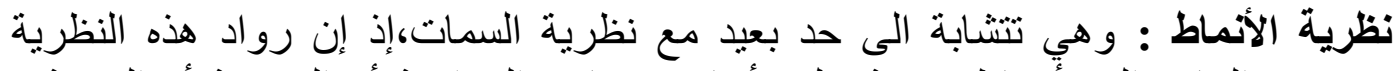

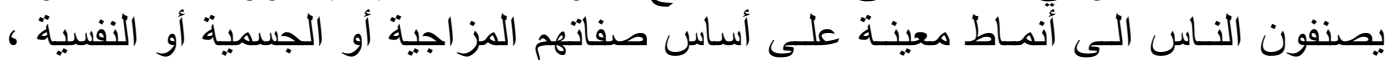

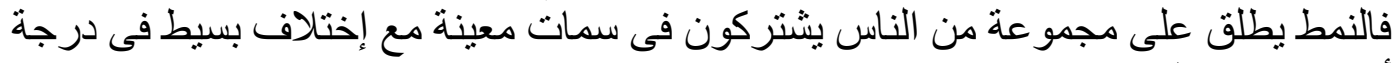

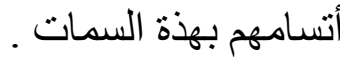

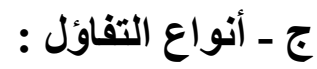
اـ التفاؤل غير الواقعى : ويعرف بمدى توقع الفرد غالباً لحدوث أحداث إيجابية متتوعة

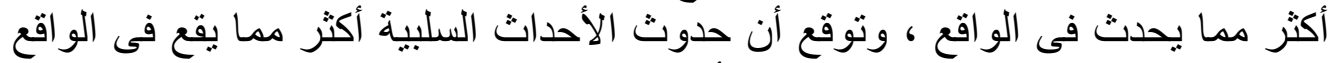

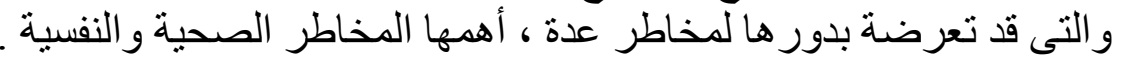

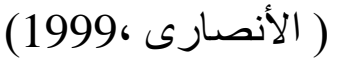

r- التفاؤل الواقعى ( الديناميكى ) : وهو يعكس اتجاة عقلانى نحو أمكانياتتا الفردية

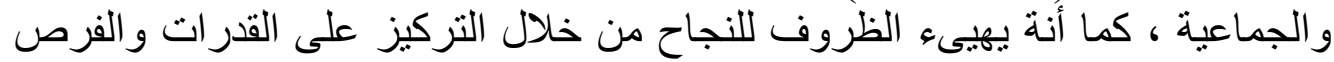
ويفسر هذا النوع من التفاؤل الخبرات بشكل إيجابى كما يؤثر على النتائج بصورة

) إيجابية

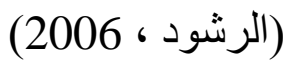

فروض الدراسة : ويتم صياغتها فى ضوء أسئلة الدراسة وأهدافها ونتيجة تحليل الدراسات السابقة كما يلى : فرونة 1 - التفاؤل و الأمل منبئان أساسيان للصمود النفسى لدى طلبة الجامعة .

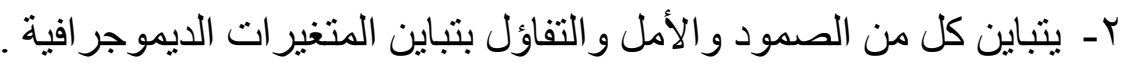


أولاً : منهج الدراسة : إعتمدت هذه الدراسة على "المنهج الوصفى الأرتباطى " ؛ لكونه أكثر

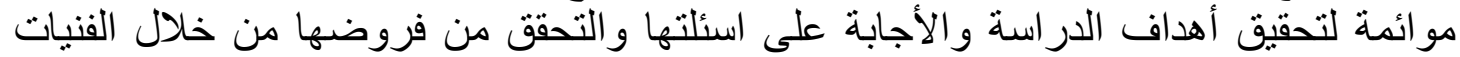

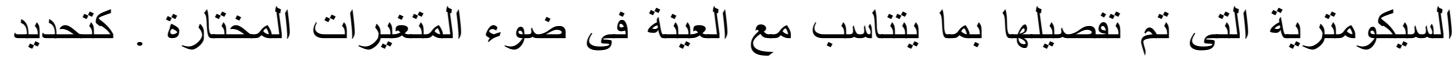

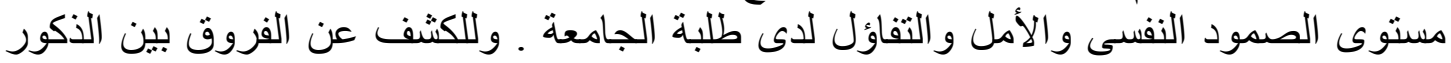

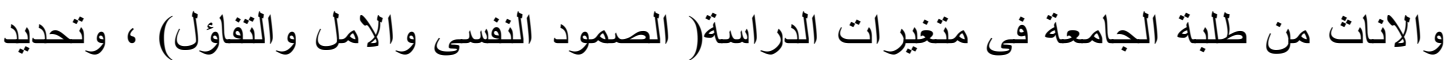

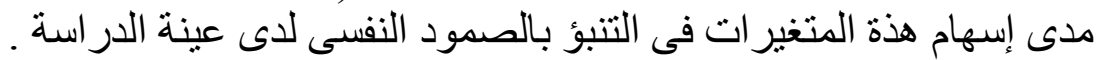
ثانياً: خصائص العينة ومنطق أختيارها : تتكون عينة الدراسة (ن =200) من طلبة الجامعة من

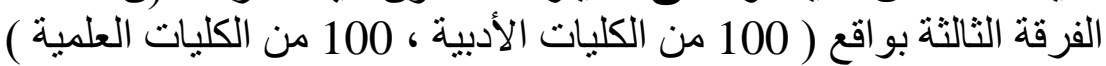

\begin{tabular}{|c|c|c|c|}
\hline المجموع & اناث & ذكور & التخصص/النوع \\
\hline 100 & 50 & 50 & العلمى \\
\hline 100 & 50 & 50 & الأدبى \\
\hline 200 & 100 & 100 & المجموع \\
\hline
\end{tabular}

أ - يقدر عدد العينة (200) لجمع البيانات الديموجر افية والتحقق من الكفاءة السيكومترية لأدوات

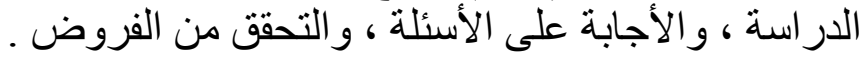

بـ تضمنت العينة ذكور وإناث ، وتخصص علمى وأدبى لحسم الجدل بين نتائج الدراسات

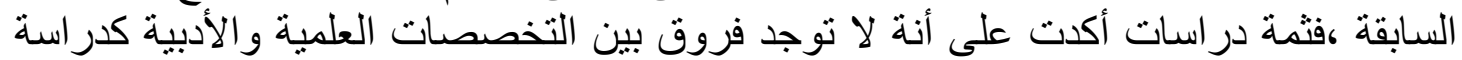

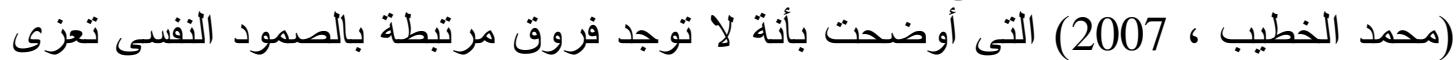

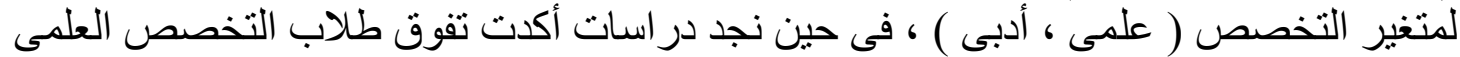

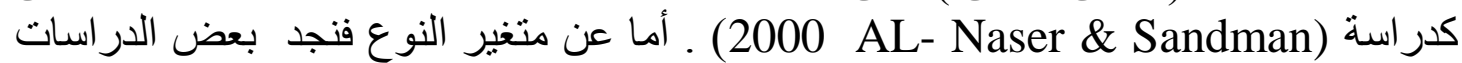

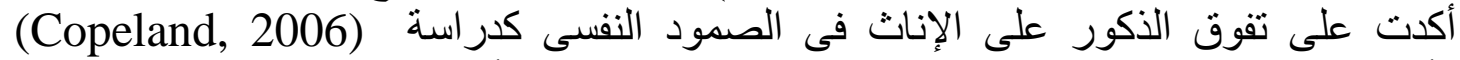

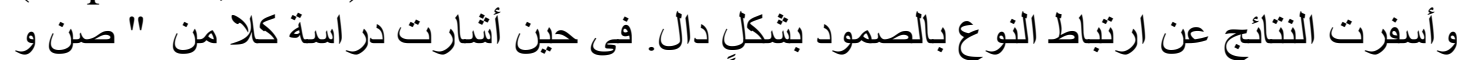

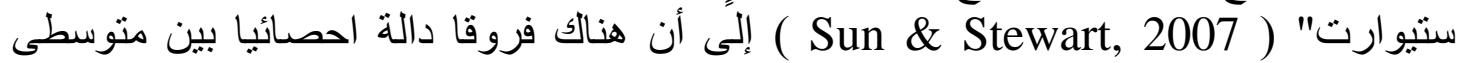
درجات الذكور و الإناث على مقياس الصمود النفسى لصالح الإناث . فن فئ أدوات الدراسة : وتتضمن ما يلى :

1 - مقياس الصمود النفسى : تم إعدادة بهدف توفير مقياس بلائم طلبة الجامعة وخصائصهم المختلفة ، بالأضافة إلى أثراء مكتبة القياس النفسى بمقاييس جديدة مستمدة من البيئة و التقافة العربية وتم إعدادة وفق المر احل التالية : المرحلة الأولى : استقر اء التراث النظرى المعنى بالصمود النفسى وتعريفاتة وسمات الأشخاص

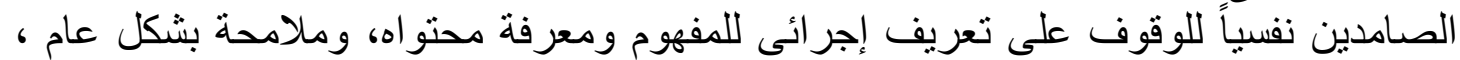

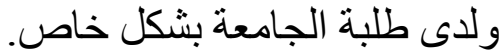

المرحلة الثاتية : والتى تضمنت تحديد مكونات المقياس ، وتم ذلك عن طريق عدة مصادر

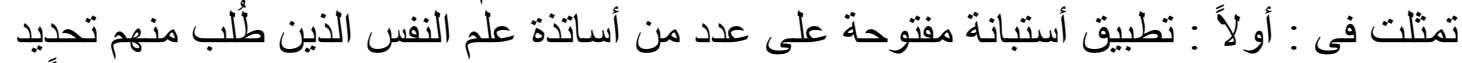

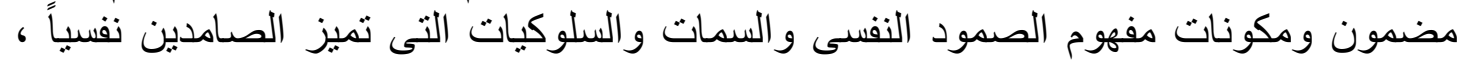

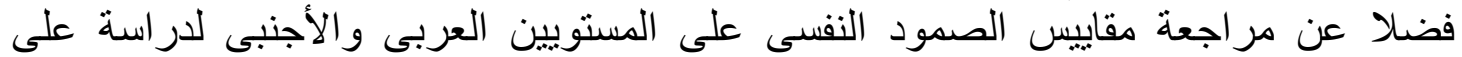
مكوناتهاو الأستفادة منها في أعداد المقايس المقياس . 
المرحلة الثالثة : فى ضوء تحليل نتائج المرحلتين السابقتين تم تحديد مكونات المقياس حيث

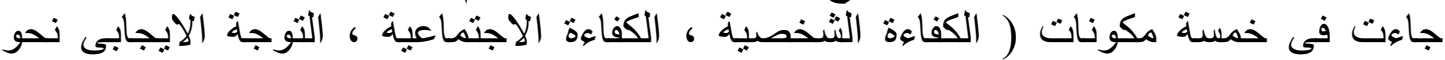

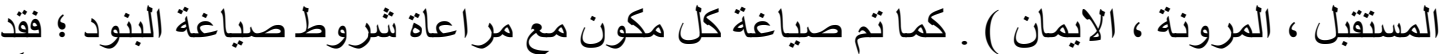

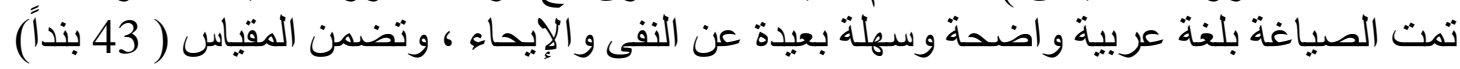

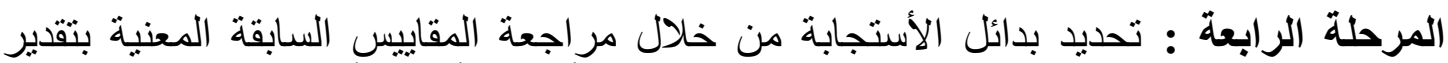

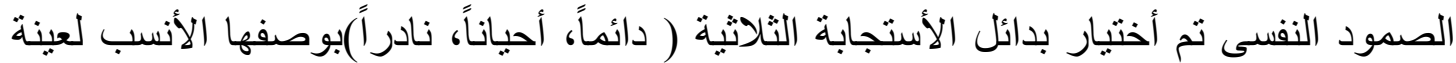

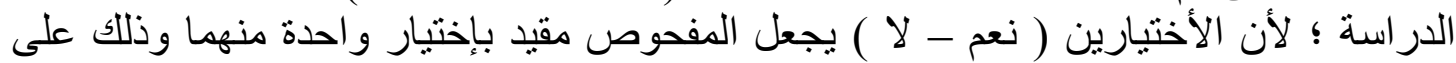

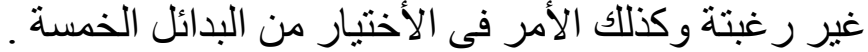

المرحلة الخامسة : تحكيم المقياس : تم عرض المقياس على ثناثنة من أساتذة علم النفس لإبداء

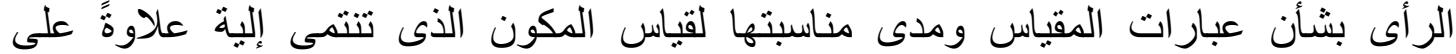

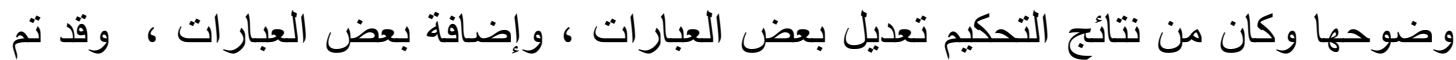
تفعيل ملاحظتهم. المرحلة السادسة : التحقق من الكفاءة السيكومترية للمقياس وقد تم إجراء الأتى : أ ـ الثبات : تم حسابة عن طريق معامل ألفا كرونباخ وذللك ( للتحقق من الثبات) وبلغ معامل الثبات ( 806. ) ) ، وكذلك عن طريق التجزئة النصفية وذللك ( للتحقق من الثبات عبر عبر خلاتيا

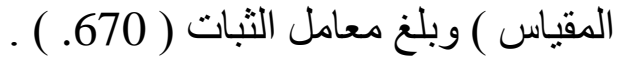

جدول (1) معاملات الثبات الفا كرونباخ والتجزئة النصفية لمقياس الصمود التفسى

\begin{tabular}{|c|c|c|}
\hline التجزئة النصفية & ألفا كرونباخ & مكوتات للمقيلس/ معامل الثبات \\
\hline .883 & .635 & الكفاءة الثخصية \\
\hline .693 & .710 & الكفاءة الإجنماعية \\
\hline .813 & .740 & التوجة الايجابى نحو المستقبل \\
\hline .704 & .666 & المرونه \\
\hline .635 & .682 & الايمان \\
\hline .670 & .806 & الصمود النفسى \\
\hline
\end{tabular}

ب ـ الصدق : تم التحقق منة عن طريق صدق المحكمين ، وسبقت الأشارة الية فى المرحلة الخامسة دن مر احل بناء المقياس ، كما تم حساب صدق البناء و التكوين: ويقصد به مدى تمثيل المقياس للظاهرة التى يضطلع لقياسها ، ولتحقيق هذا النوع من الصدق فئ فقد تمت صياغة بن بنود

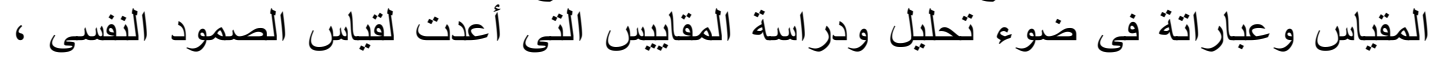

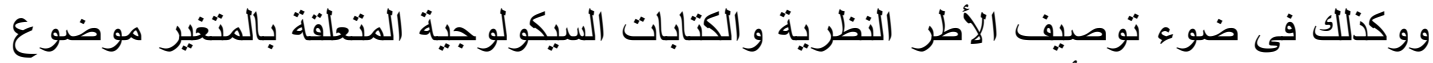
الدر اسة ـ و التى سبق الأشارة الية .

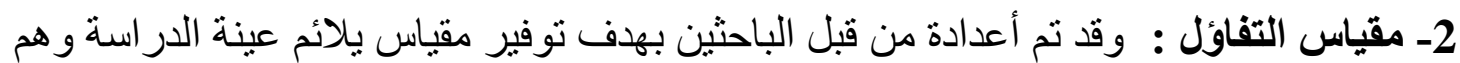

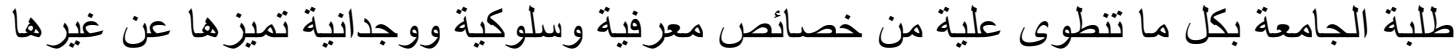
من عينات ، بالأضافة إلى أثراء مكتبة القياس النفسى بمقاييس جديدة مستمدة من البيئة والثقافة 
العربية ، ويتكون المقياس من 32 عبارة وزعت على ثلاثة مكونات فرعية نشير لها منبو عة بتعريفاتها الأجرائية . تئكون

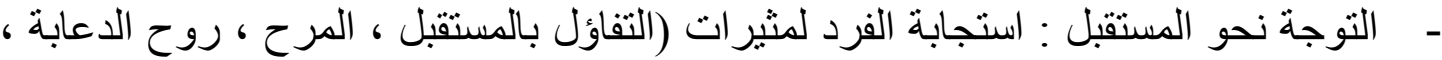
ادر الك هدف للحياة ، حل المشكلات ، التقة بالنفس ، التفاؤل بالخير).

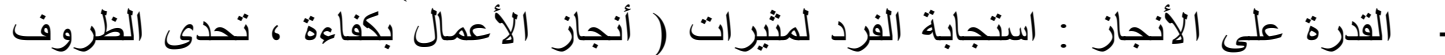

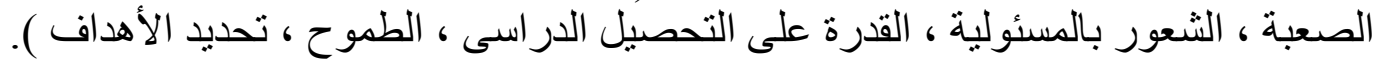

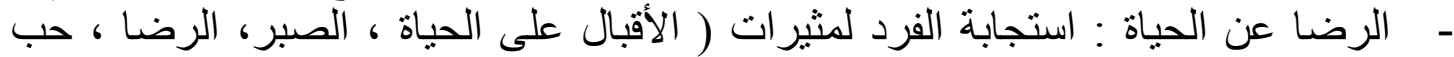
الأخرين ، تكوين علاقات طيبة مع الأخرين ).

وقد تم تحديد بدائل الأستجابة من خلال مراجعة المقاييس السابقة المعنية بتقدير التفاؤل وتم

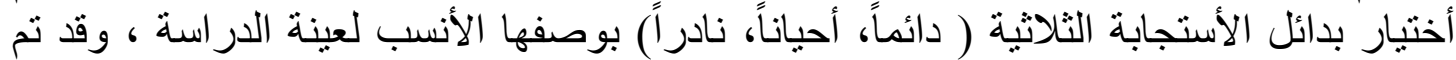
حساب الخصائص السيكومترية للمقياس من خلال حساب الثبات عن طريق الأتى :

أو لا" : ثبات المقياس : تم حسابة عن طريق معامل ألفا وذلك ( للتحقق من الثبات) وبلغ معامل

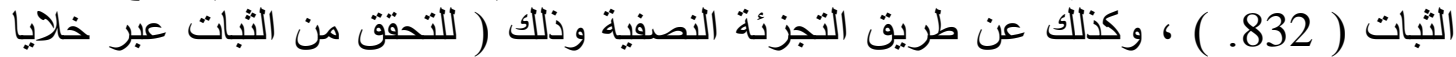
المقياس ) وبلغ معامل الثبات ( 831. ) اللارجة الكلية ؛ مما يعنى أن المقياس بتمتع بمعامل ثبات جيد ـ ونوضح ذللك فى الجدول معلمي التالى : جدول (2) معاملات الثبات الفا كرونباخ والتجزئة النصفية لمقياس التفاؤل

\begin{tabular}{|c|c|c|}
\hline التجزئة النصفية & ألفا كرونباخ & مكونات المقياس/ معادل للثيات \\
\hline .835 & .744 & التوجة نحو المستقبل \\
\hline .883 & .788 & القدرة على الأنجاز \\
\hline .821 & .722 & الرضا عن الحياة \\
\hline .881 & .832 & التفاؤل \\
\hline
\end{tabular}

ثانياً : صدق المقياس : تم التحقق منة عن طريق صدق المحكمين ، وكذلك الصدق التكوين و المحتوى : ويقصد به مدى تمثيل المقياس للظاهرة التى يضطلع لقياسها وتشخيصها ، و ولتحقيق

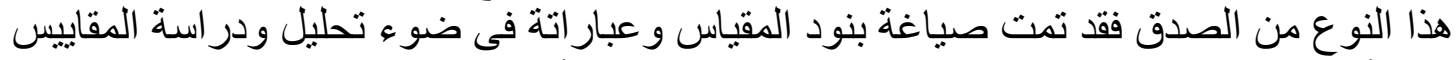

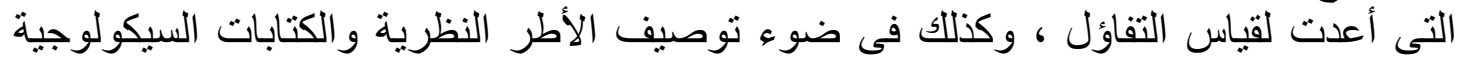
المتعلقة بالمتغير موضوع الدر اسة ـ و والتى سبق الأشارة الية.

3 - مقياس الأمل : تم أعدادة من قبل الباحثين بهدف توفير مقياس يلائم عينة الار اسة وهم طلبة

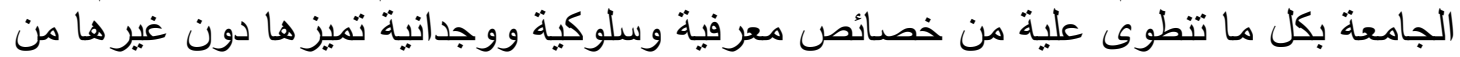

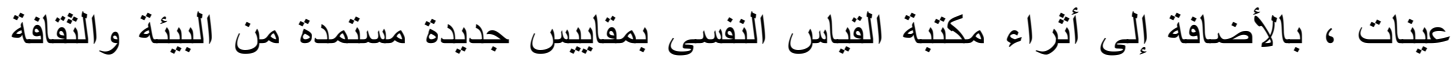

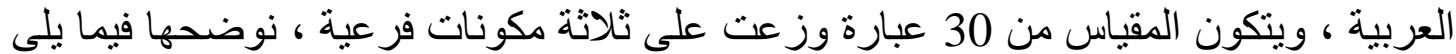

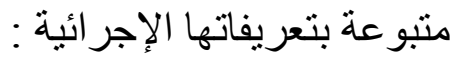

- قوة الأرادة : استجابة الفرد لمثيرات ( الأنجاز ، تحقيق النجاح ، الرضا ، حل المشكلات ،

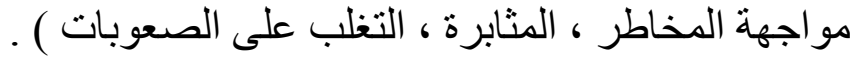


- النظرة الإيجابية للمستقبل استجابة الفرد لمثيرات ( التخطيط للمستقبل ، الصلابة ،

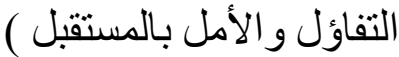
ـ تحقيق الأهداف : استجابة الفرد لمثيرات ( العزم ، الأرادة ، القدرة على التطوير ، الثقة بالنفس ، تحقيق النجاح ).

وقد تم تحديد بدائل الأستجابة من خلال مر اجعة المقاييس السابقة المعنية بتقدير الأمل وتم أختيار

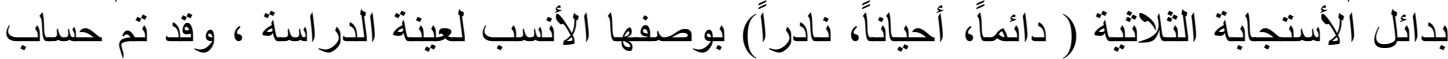
الخصائص السيكومترية للمقياس على النحو التالى :

أو لا" : ثبات المقياس : تم حسابة عن طريق معامل ألفا وذلك ( للتحقق من الثبات) وبلغ معامل

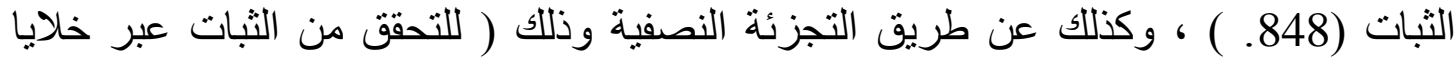

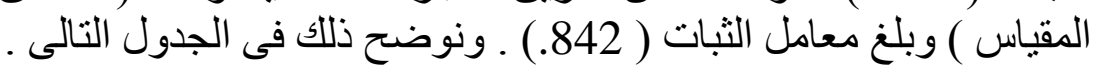
جدول (3) معاملات الثبات الفا كرونباخ والتجزئة النصفية لمقياس الأمل

\begin{tabular}{|c|c|c|}
\hline التجزئة النصفية & ألفا كرونباخ & مكونات المقياس/ معكل للاتثيات \\
\hline .633 & .833 & قوة الأر ادة \\
\hline .822 & .688 & النظرة الإيجابية للمستقبل \\
\hline .725 & .735 & تحقيق الأهداف \\
\hline .842 & .848 & الأمل \\
\hline
\end{tabular}

ثانياً : صدق المقياس : تم التحقق منة بعدة طرق منها : صدق المحكمين ، وقد سبق الأشارة إلية

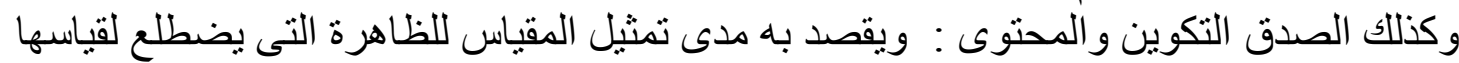

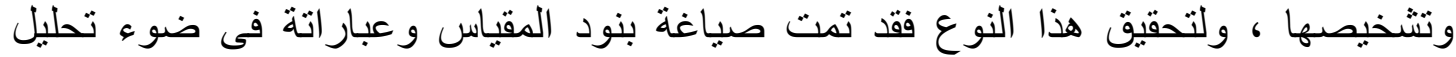

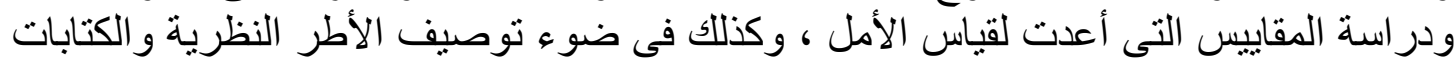
السيكولوجية المتعلقة بالمتغير موضوع ألدو الدر اسة ـو وقد سبق الأشارة الية. نتائج الاراسة ومناقشتها : على التحو التالى : الفرض العام الأول : والأى ينص على " التفاؤل والأمل منبئان أساسيان للصمود النفسى لاى

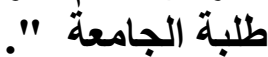

واللتحقق من هذا الفرض تم أستخدام تحليل الأنحدار الخطى المتعدد SSSear regression

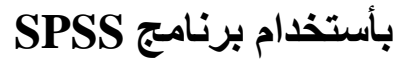

ويستخدم الأنحدار الخطى المتعدد للتنبؤ بدرجات المتغير التابع ( الصمود النفسى ) من درجات

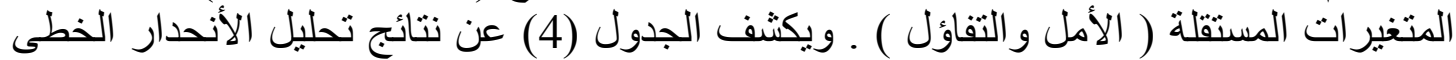

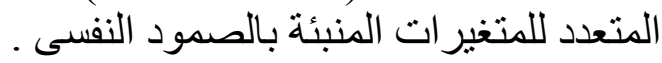

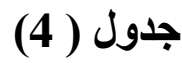

نتائج تحليل الأنحار للمتغيرات

الأمل و التفاؤل المنبئة بالصمود النفسى 


\begin{tabular}{|c|c|c|c|c|c|c|c|c|}
\hline $\begin{array}{r}\text { مستوى } \\
\text { sig }\end{array}$ & قيمة F & $\begin{array}{r}\text { معامل } \\
\text { R- } \\
\text { Rquare }\end{array}$ & $\begin{array}{r}\text { معامل } \\
\text { الارتباط } \\
\text { (R) }\end{array}$ & الدلالة & قيمة & $\begin{array}{r}\text { الأنحارل } \\
\text { القياسى } \\
\text { Beta }\end{array}$ & $\begin{array}{c}\text { الأنحدار ( معامل } \\
\text { (B }\end{array}$ & المنبى المتير به \\
\hline \multirow{3}{*}{0.0001} & & \multirow{3}{*}{0.76} & \multirow{3}{*}{0.276} & 0.0001 & 2.787 & 0.199 & 0.240 & الأمل \\
\hline & 57.209 & & & 0.001 & 3.586 & 0.256 & 0.239 & التفاؤل \\
\hline & & & & 0.0001 & 13.000 & & 97.653 & 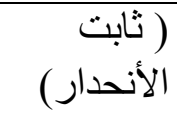 \\
\hline
\end{tabular}

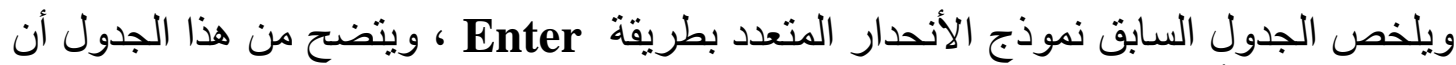

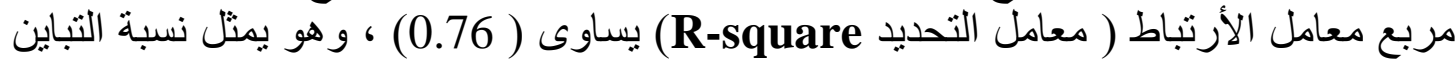

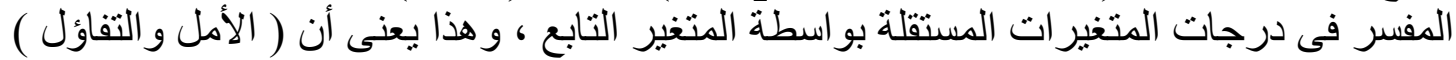

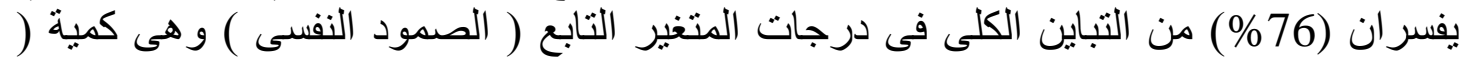

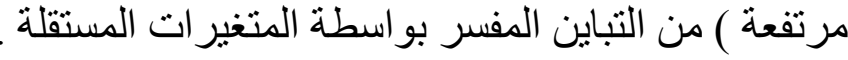

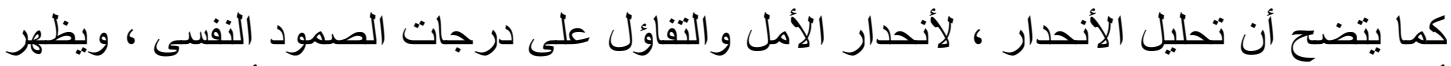

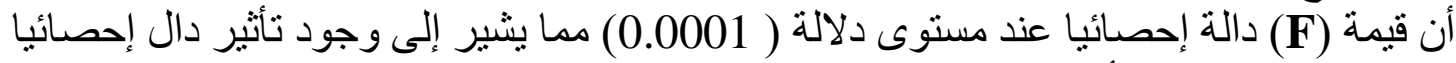
للمتغير ات المستقلة (الأمل والتفاؤل ) على المتغير التابع ( الصمود النفسى ) .

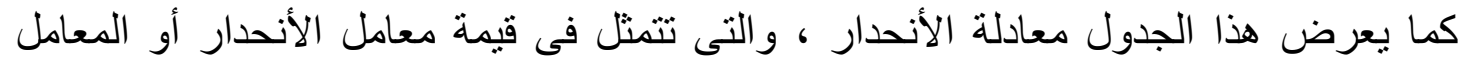

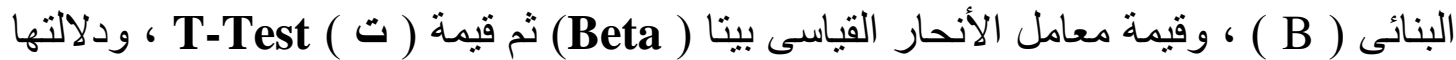

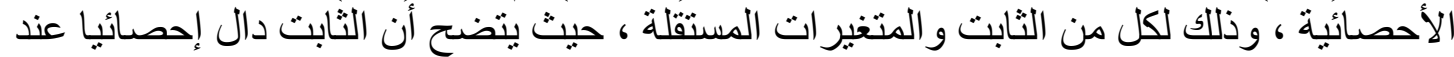

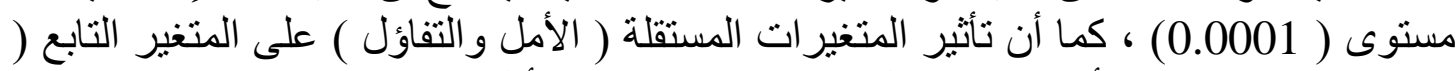
الصمود النفسى ) كان تأثير موجما انب دال إحصائيا عند مستوى أقل من (0.0001) .

وبالتالى يمكن صياغة معادلة الأندار التى تساعد فى التتبؤ بالصمود النفسى من خلال بيانات الجدول السابق فى الصورة التالية :

القيمة المتوقعة للأمل +التفاؤل = 0.497 - ( الصمود النفسى ) 97.653 أى أن درجات المتغير ات المستقلة ( الأمل و التفاؤل ) منبئان بشكل دال بالمتغير التابع ( الصمود النفسى) . (الن درات

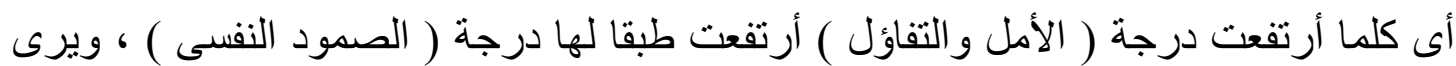

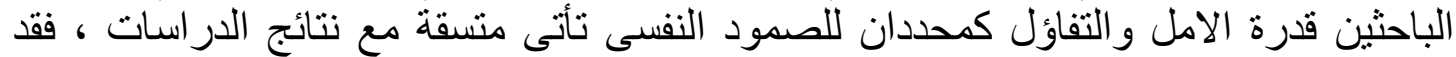
أكدت دراسة إيجر (Eger,1998) على وجود الإن علاقة موجبة بين الصمود النفسى والأمل

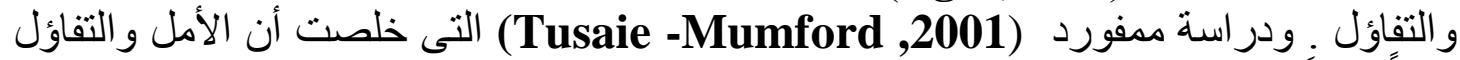

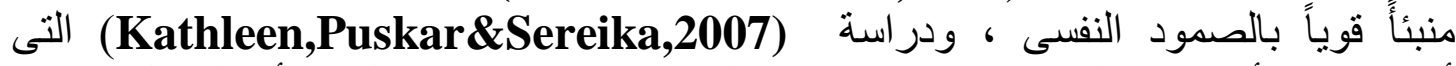

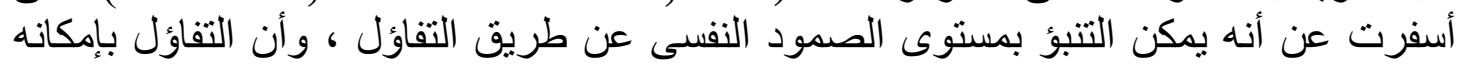

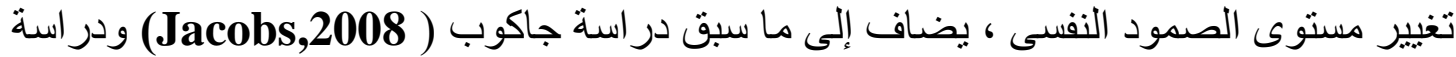
(Siemens,2008) وتتفق هذة الدراسة مع دراسة ( Parvizian,2004) وكيم ( Kim,2005) بأن الأمل يرتبط الأبط بالصمود النفسى ويسهم فى نموة ، وهو ما أكده لينج ( laing,2005) من أن الأمل و التفاؤل الأل 
مفاتيح تسهم فى نمو الصمود النفسى ، ودراسة (2010, Collins) التى أكدت على وجود

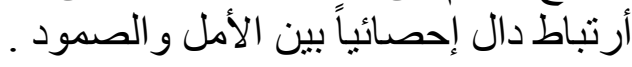

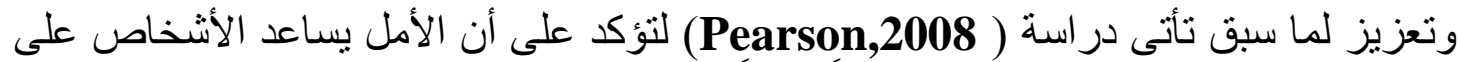

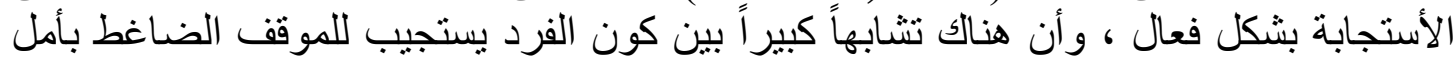

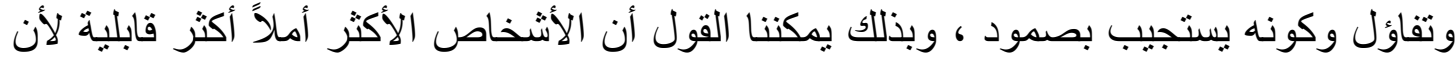

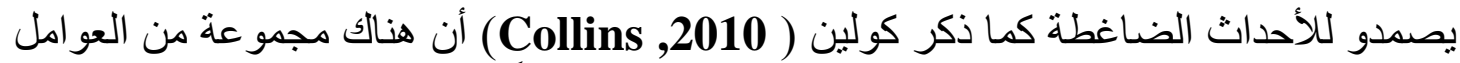

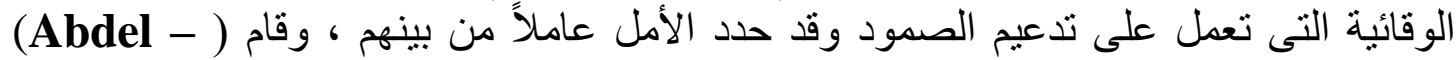
جبار Khalek \& Snyder, 2007

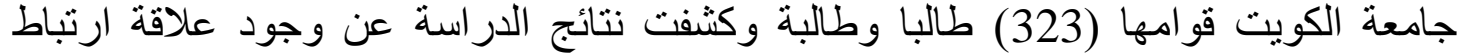

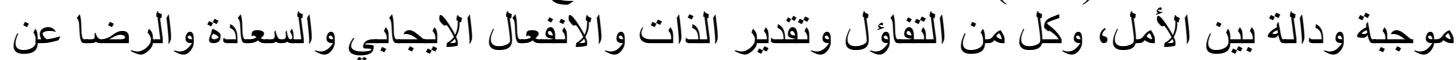

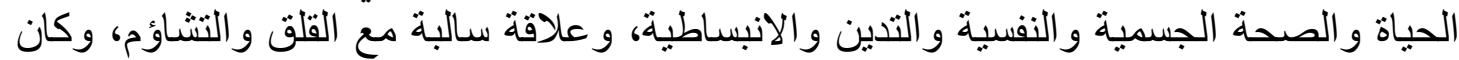
أفضل منبئ للأكل و التفاؤل، يليه الانفعال الايجابي و وتقدير الذات.

وأجرى راند ( Rand, 2009 (312) دراسة تناولت الأمل والتفاؤل لدى عينة من طلبة الجامعة

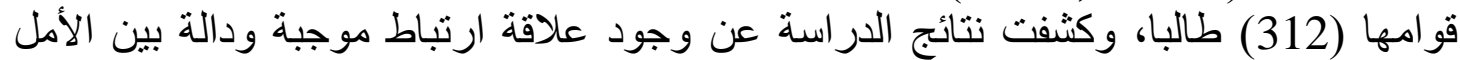

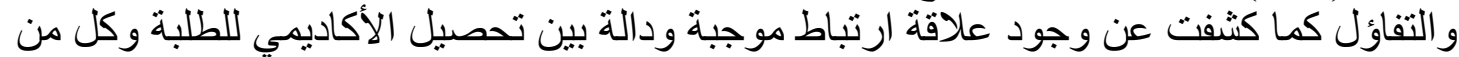

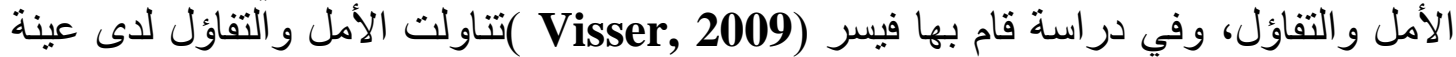

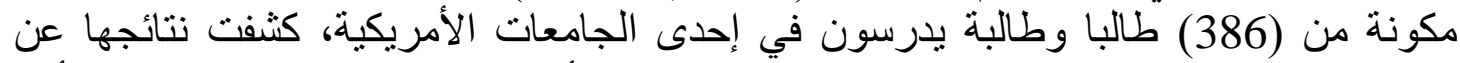

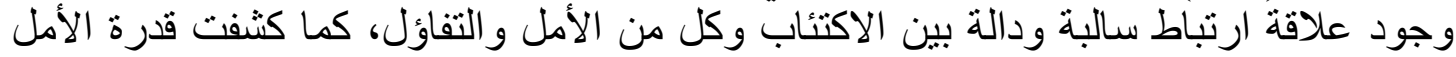
و التفاؤل على التقليل من الآثار السلبية لأحداث الحياة الصنية الصعبة.

Bيث اكد على ذلك بيرنارد وآخرون Bernard, Hatchison, Lavin \& Pennington

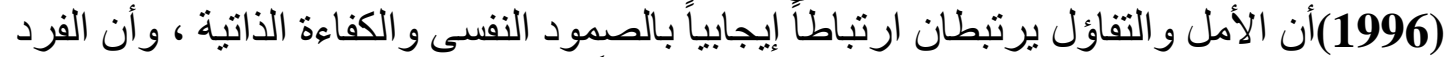

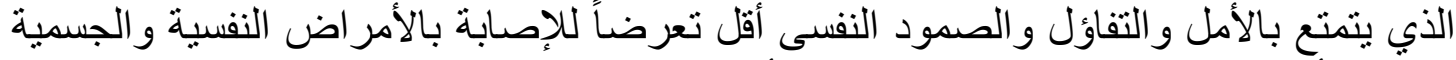

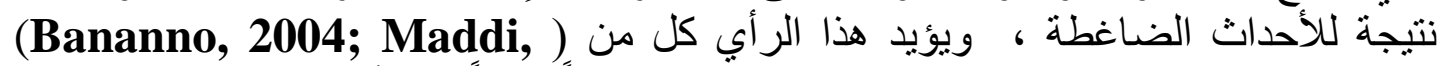
2004; Oullete, 1993

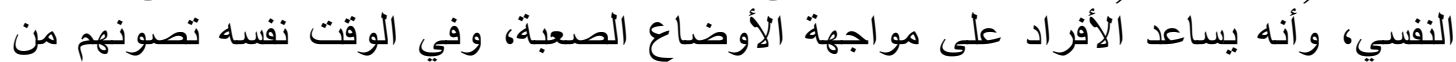

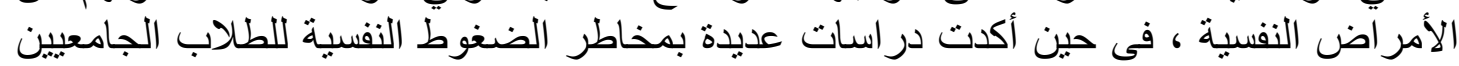

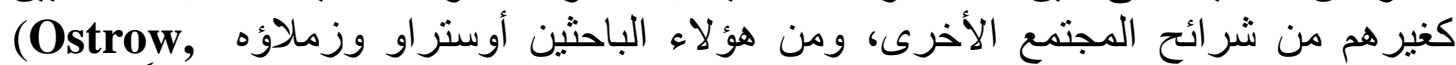
الذين بعتقدون أن الطلاب الجامعيين عموماً بفتقرون إلى الصحة النفسية؛ إذ إنهم يعيشون نوبات الضغوط النفسية المتكررة ، وقد وجد الند خانا وخانا، وبولجر ( (Bolger, 1997; Khanna \& Khanna, 1990) أن من أكثر مصادر الضغوط لدى الطلبة الجامعيين، الضغوط الأكاديمية، ومن أهمها قلة وقت الدراسة، وكثرة ما

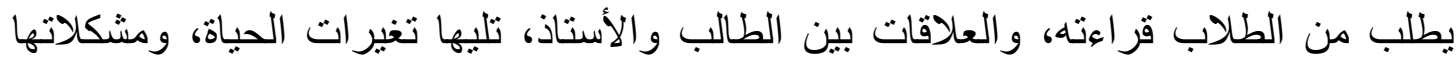

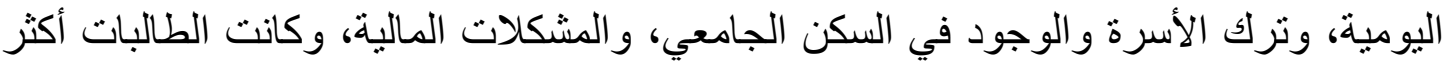

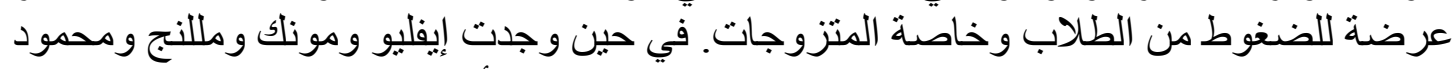
أن الطلبة الجامعبين يعانون من (Evellyu, Monk, Milling \& Mahmour, 1999 ) الضغوط النفسية الثديدة بسبب الصعوبات المالية، وصعوبات المقرر ات الدئ الدر اسية ، ويظهر تأنثير

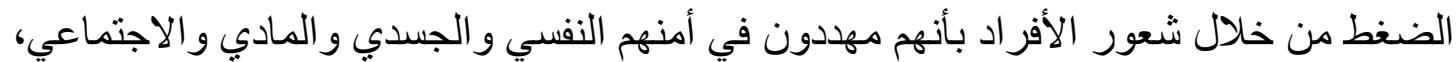

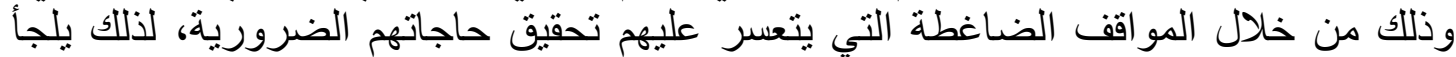
Khanna البعض إلى تبني بعض الاستر اتيجيات للتقليل من آثار الضغوط؛ فقد وجد خانا وخانا (\& Khanna, 1990) آثنار الضغوط الأكاديمية، كان من أهمها النشاط الرياضي، والبوح بالمعاناة الوجدانية إلى الى الى 
الزملاء، والالتزام والتحدي والصدود النفسى ، أما باتون وجولدنبرج \&atton \& ) Goldenberg 1999)

الصمود النفسى ونسبة منخفضة من القلق، وهذه النتيجة تؤكدها دراسة بيرنارد وآخرين ) Bernard et al., 1996) ارتباطاً عالياً بالإنجاز الأكاديمي وتقدير الذات والكفاءة الذاتية والثعور بالأمل و التفاؤل.

وبالنسبة لمفهوم الثعور بالأمل، فإنه يعد من أهم المفاهيم النفسية في علم النفس الإيجابي، وآثاره الإيجابية عديدة على الصحة النفسية والجسمية، ومقاومة الضغوط الحياتية والإنجاز الأكاديمي

Kwon, 2002) (Irving \& Snyder, 1998; Snyder et al., 2005). ) أن الشعور العالي بالأمل يحقق أعلى درجات التكيف والتو افق النفسي لأى طلاب الجامعة، ورذا ما أكدته دراسة (Snyder, et al., 1997; Dirac \& Cramer, 1998) التي لوني توصلت إلى العلاقة الإيجابية بين درجات الطلبة على مقياس التكيف النفسي ومقياس الثعور

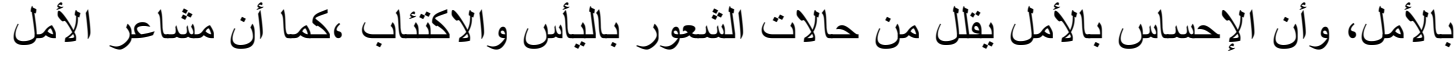

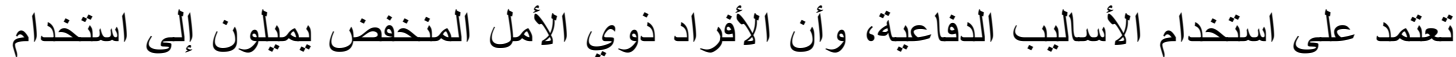

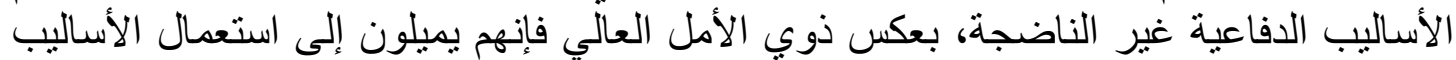

(Kwon, 2000). الدفاعية الناضجة الاضة غيرة

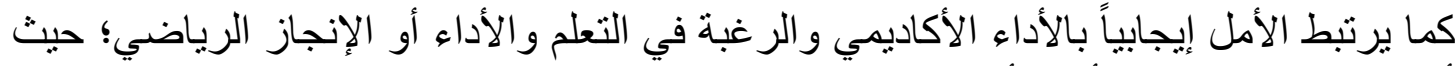

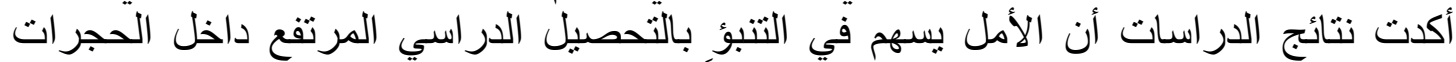

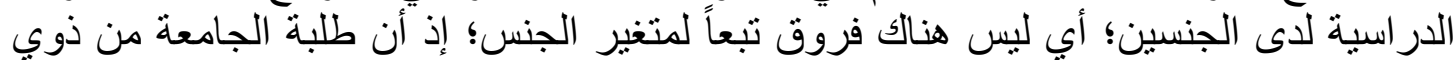

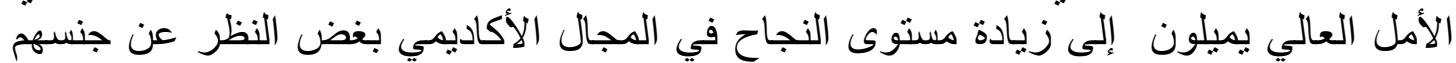
Change, ؛Curry et al., 1997 ؛Snyder \& Wiklund \& Cheavens, 1998) Snyder, et al., 2002) (1998

ويؤكد ذلك كل من: ( Snyder, et al., 2005; Margo \& Simpson, 2005; Change, 1998; Affleck \& Tennen, 1996)

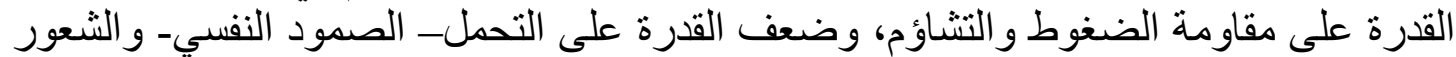
بالدونية، و انخفاض مستوى الإنجاز الدار اسي.

وتتير العديد من الدراسات إلى أن الأشخاص ذوى الأمل المنخفض هم أقل صموداً بشكل دال

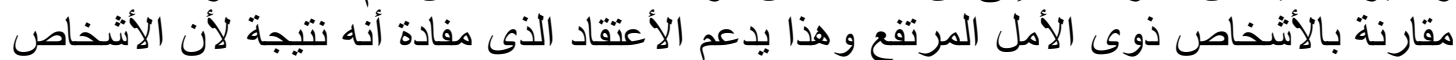

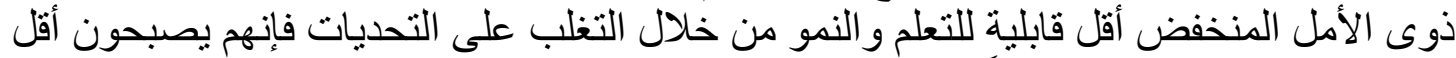

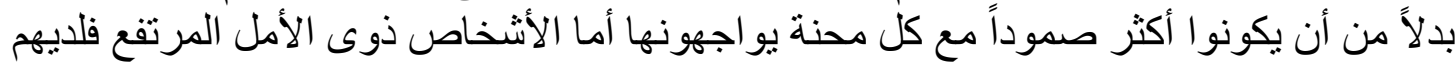

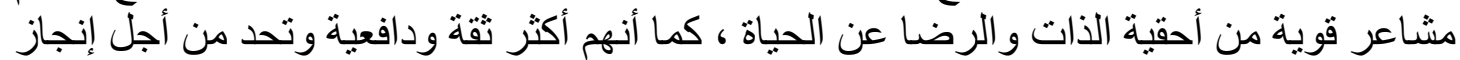

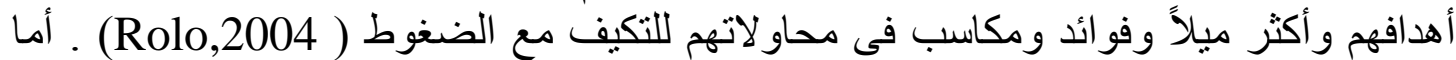

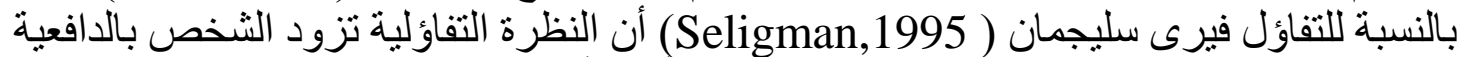
التى تساعدة على تحقيق أهدافة وأن التفاؤل يمثل هدفاً مهماً لتعزيز الصمود التهرد النفسى .

و فيما يتعلق بالتفاؤل قام تشانج و آخرون (Chang, et al., 1997 (Cبر اسة تناولت التفاؤل لدى

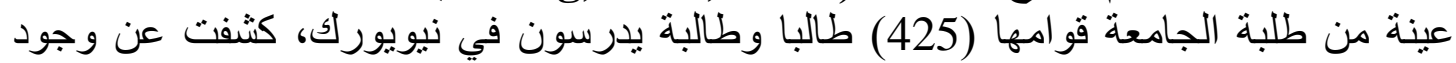

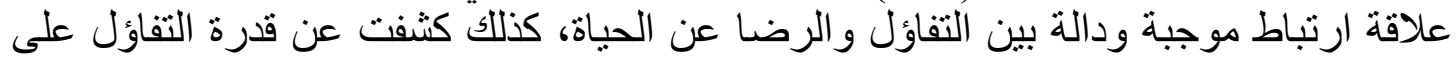

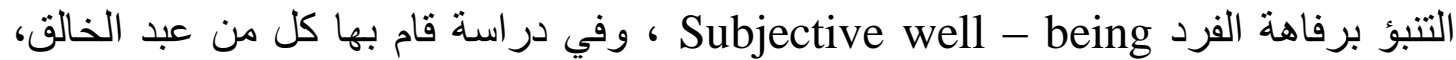

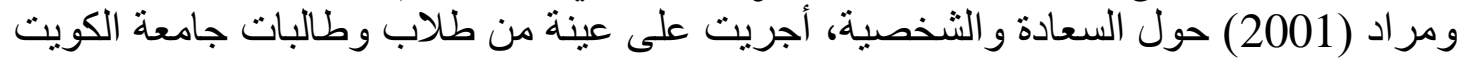

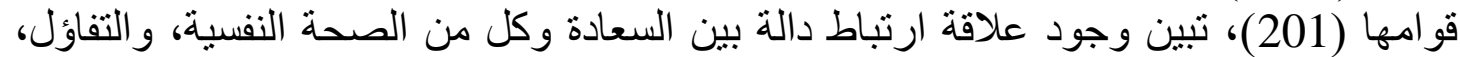

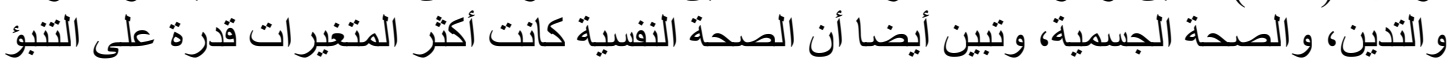


بالسعادة ، وقام بن زار (Ben - Zur, 2003) بدراسة تناولت التفاؤل لاى عينة من طلبة

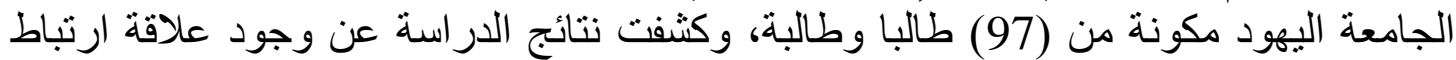

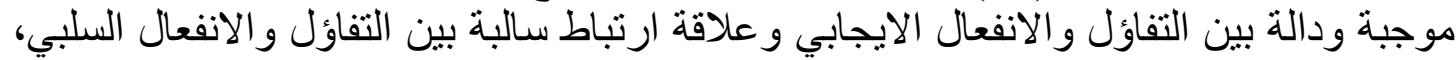
كما كثفت عن وجود علاقة ارتباط موجبة ودالة الإلة بين التفاؤل ورفاهية الو الدين لئن في حين قدم سكوت وسنايدر (Scott \& Snyder, 2005) دراسة تناولت دور الأمل في

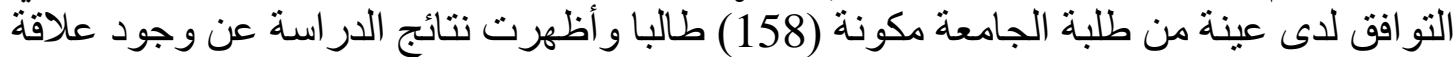

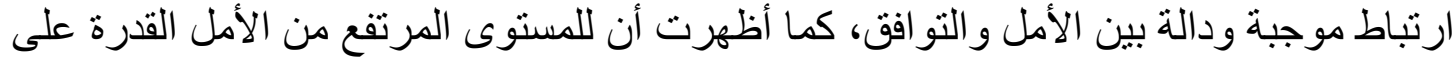

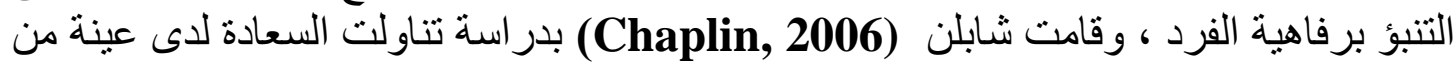

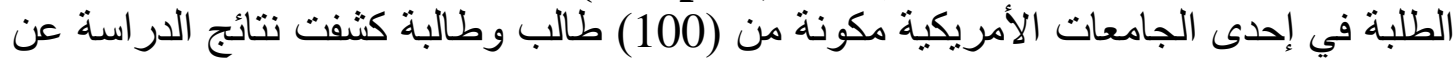

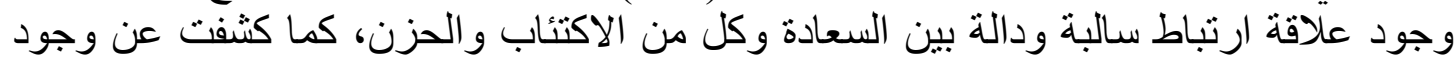

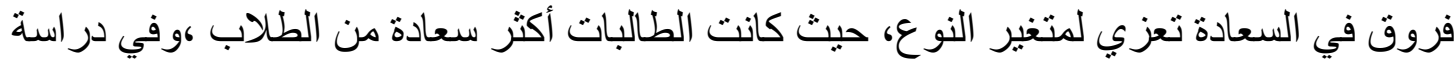

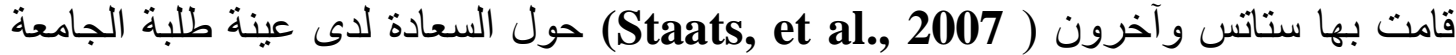

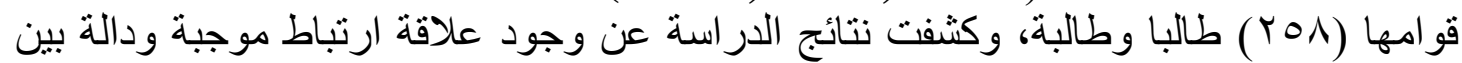

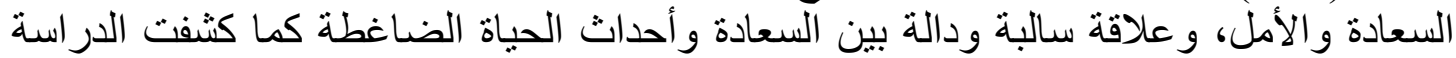

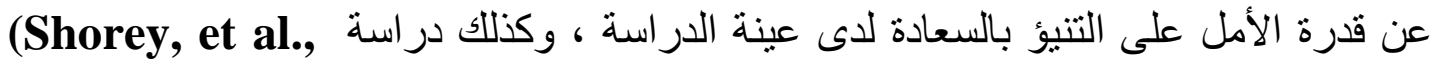

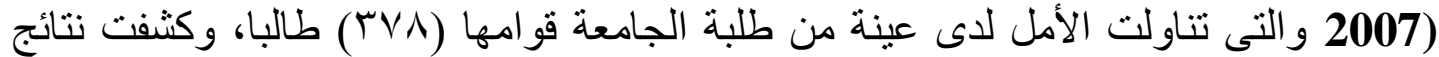

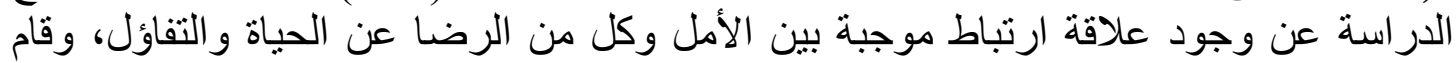

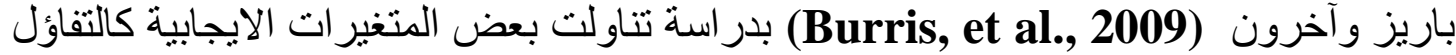

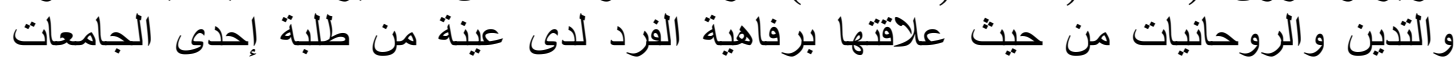

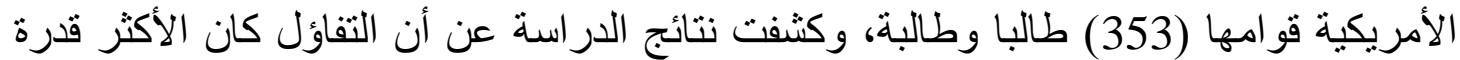

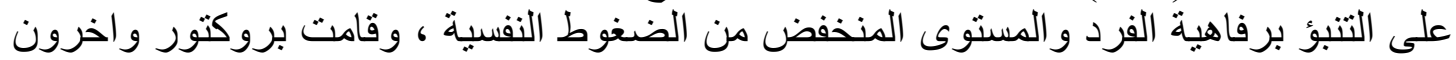
(Proctor, et al., 2010)

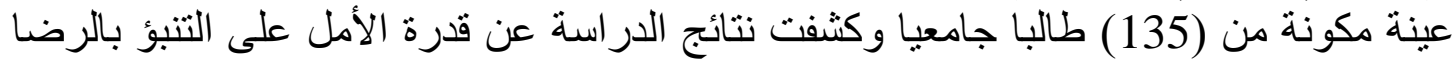

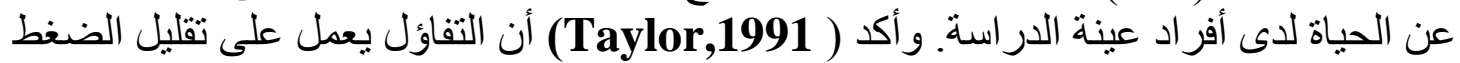

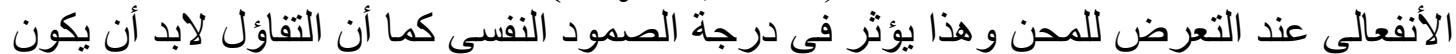

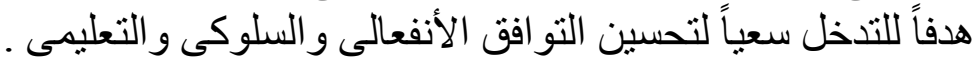

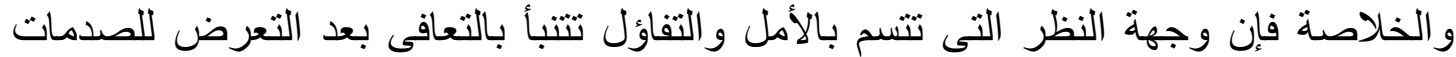

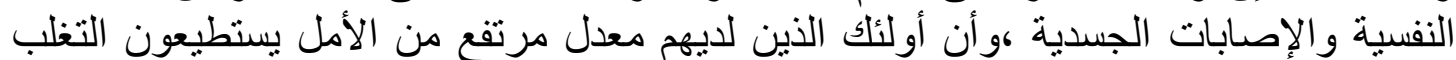

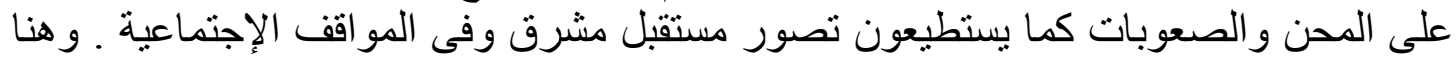

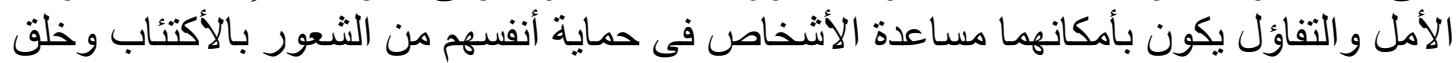

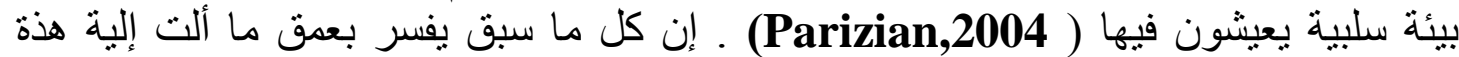

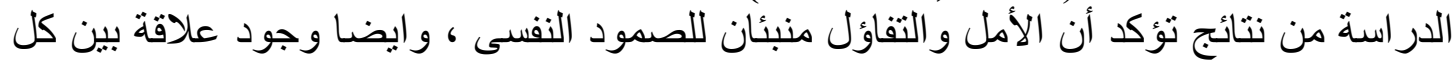

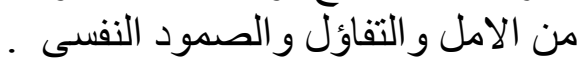

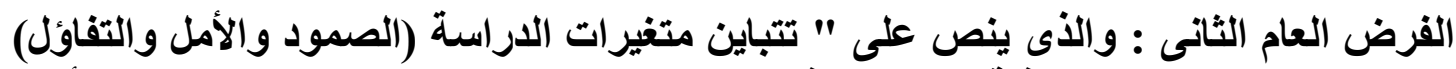

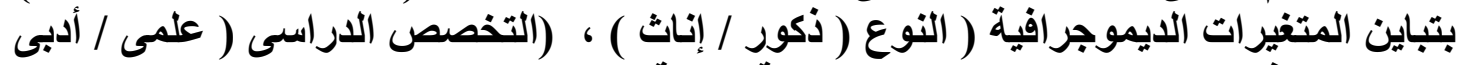
)"، ومن هذا الفرض تتفرع الفروض الفرعية التالية : أ - تتباين كل من (الصمود و الأمل و التفاؤل) ومكوناتهما بتباين النوع ( ذكور - إناث )، لاى الد 
وللتحقق من هذا الفرض يمكن صياغتة بأسلوب إحصائى صفرى كالتالى : لا توجد فروق دالة

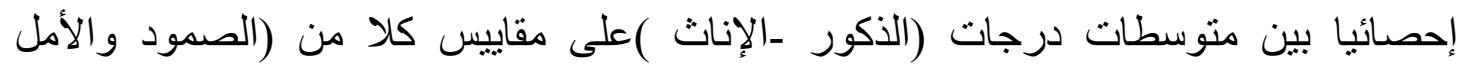
و التفاؤل ) ومكوناتهم .

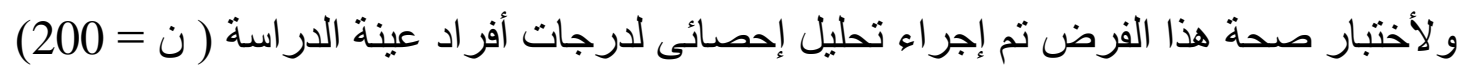

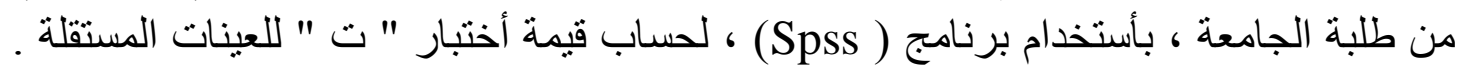

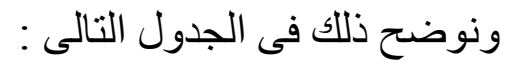

جدول ( 5) قيمة (ت ) لالالة الفروق بين ( ذكور- إناث ) على مقاييس

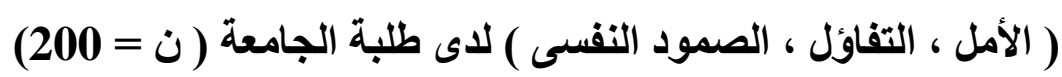

\begin{tabular}{|c|c|c|c|c|c|c|c|}
\hline مستوى & "تيمة & المعيارى الأحراف & المتوسط & العدد & النوع & المكونات & الاقنيل لايتيرات \\
\hline .000 & 2.130 & $\begin{array}{l}1.886 \\
2.130\end{array}$ & $\begin{array}{l}23.95 \\
25.83\end{array}$ & $\begin{array}{l}100 \\
100\end{array}$ & ذإناث & التوجةّ نحو & التفاؤل \\
\hline .001 & 0.277 & $\begin{array}{l}2.500 \\
2.745\end{array}$ & $\begin{array}{l}27.00 \\
28.15\end{array}$ & 100 & ذكور & القأنجاز على & \\
\hline .001 & 1.22 & $\begin{array}{l}1.646 \\
2.226\end{array}$ & 22.56 & $\begin{array}{l}100 \\
100\end{array}$ & ذكور & الرضاة عن & \\
\hline .005 & 1.332 & $\begin{array}{l}6.032 \\
7.101\end{array}$ & $\begin{array}{l}73.51 \\
77.25\end{array}$ & $\begin{array}{l}100 \\
100\end{array}$ & ذكور & للأختبار الكلية & \\
\hline .000 & 2.500 & $\begin{array}{l}1.130 \\
2.150\end{array}$ & $\begin{array}{l}22.95 \\
23.95\end{array}$ & $\begin{array}{l}100 \\
100\end{array}$ & ذإناث & قوة الأرادة & \\
\hline .001 & 1.000 & $\begin{array}{l}2.100 \\
2.199\end{array}$ & $\begin{array}{l}20.05 \\
22.99\end{array}$ & 100 & ذإناث & اللإيجابية & الامل \\
\hline .001 & 2.900 & $\begin{array}{l}1.100 \\
2.180\end{array}$ & $\begin{array}{l}21.75 \\
23.15\end{array}$ & $\begin{array}{l}100 \\
100\end{array}$ & ذإناث & الأهدافق & \\
\hline
\end{tabular}




\begin{tabular}{|c|c|c|c|c|c|c|c|}
\hline \multirow[t]{2}{*}{.005} & \multirow[t]{2}{*}{2.000} & 4.33 & 64.75 & 100 & ذكور & \multirow{2}{*}{ للأختبار الكلية } & \\
\hline & & 6.529 & 70.09 & 100 & إناث & & \\
\hline \multirow[t]{2}{*}{.001} & \multirow[t]{2}{*}{0.500} & 1.100 & 20.05 & 100 & ذكور & \multirow[b]{2}{*}{ الكفاءة } & \multirow{13}{*}{ الصمود } \\
\hline & & 2.180 & 25.95 & 100 & 1 & & \\
\hline \multirow[t]{2}{*}{.001} & \multirow[t]{2}{*}{2.820} & 1.230 & 21.95 & 100 & ذكور & \multirow[b]{2}{*}{ الكفاعة } & \\
\hline & & 2.233 & 23.55 & 100 & 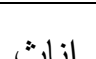 & & \\
\hline \multirow[t]{3}{*}{.001} & \multirow[t]{3}{*}{2.580} & 1.030 & 22.25 & 100 & ذكور & & \\
\hline & & 2.030 & 24.05 & 100 & & التوجه & \\
\hline & & & & & & المستقبل & \\
\hline \multirow[t]{2}{*}{.005} & \multirow[t]{2}{*}{1.050} & 1.190 & 21.25 & 100 & ذكور & \multirow[t]{2}{*}{ المرونه } & \\
\hline & & 2.130 & 23.95 & 100 & إناث & & \\
\hline \multirow[t]{2}{*}{.005} & \multirow[t]{2}{*}{2.200} & 1.180 & 20.85 & 100 & ذكور & \multirow[t]{2}{*}{ الايمان } & \\
\hline & & 2.150 & 21.95 & 100 & إناث & & \\
\hline \multirow[t]{2}{*}{005} & \multirow[t]{2}{*}{2.050} & 5.73 & 106.35 & 100 & ذكور & \multirow{2}{*}{ للأخجتبار الكلية } & \\
\hline & & 10.723 & 119.45 & 100 & إناث & & \\
\hline
\end{tabular}

يتضح من الجدول السابق أن قيمة " ت " لدلالة الفروق بين متوسطات أداء كل من ( الذكور الأناث ) على الدرجة الكلية لمقياس التفاؤل بلغت ( لمقياس الأمل ، وبلغت (2.050 ) للارجة الكلية لمقياس الصمود النفسى ، وجاءت كل كل القيم دالة

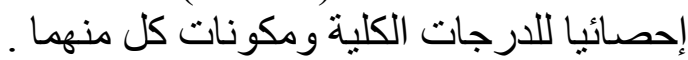

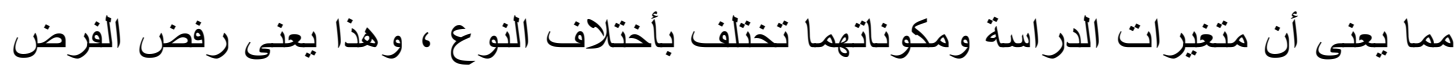
الصفرى "لا توجد فروق دالة إحصائيا بين متوسطات درجات (الذكور ـالإناث )على مقاييس

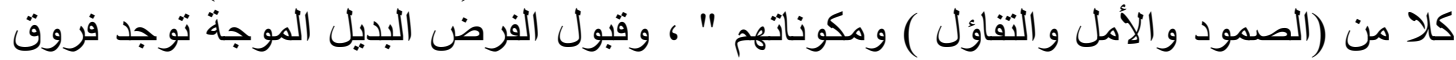

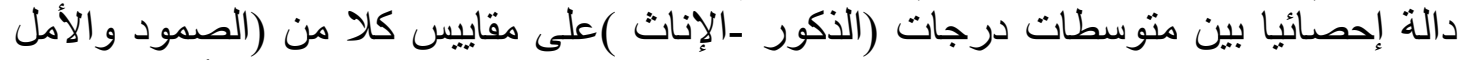

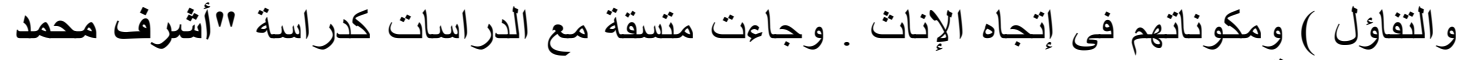

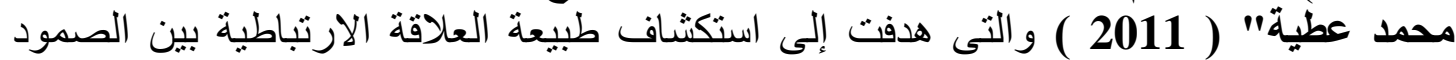

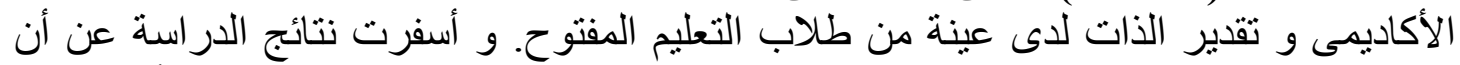
هناك علاقة ارتباطيه سالبة دالة إحصائيا بين درجات الطلاب على على مقياس الصمود الأكاديمى و 


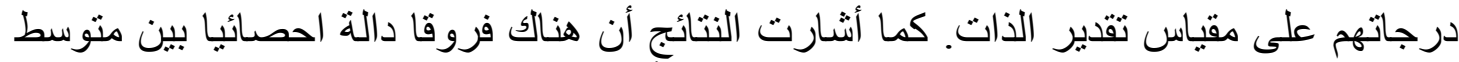

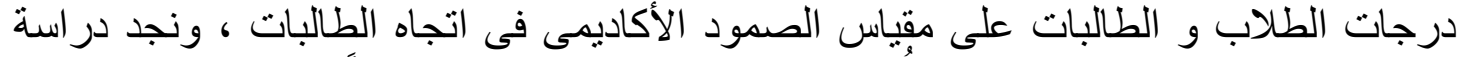

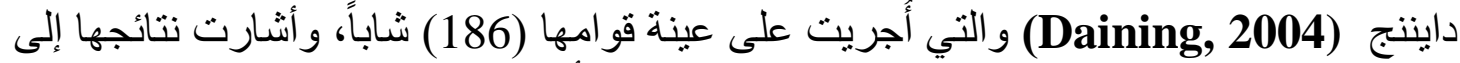
ارتباط النو ع بالصمود؛ حيث حصلت الإناث على درجات أعلى في الصمود .

فى حين كانت هنالك دراسات أظهرت تفوق الذكور على الأناث فى مستوى الصمود و والأمل

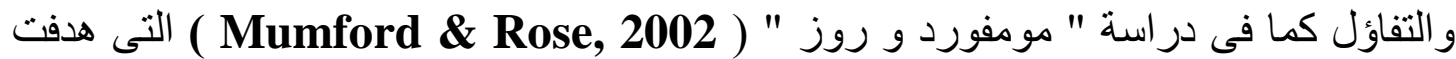

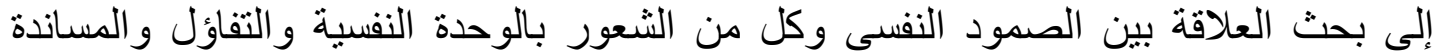

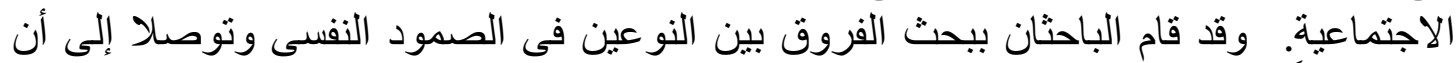

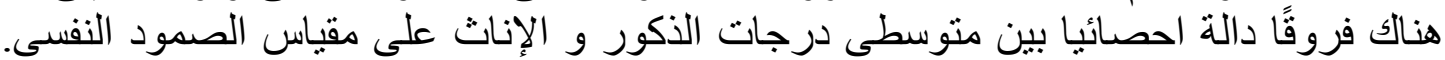

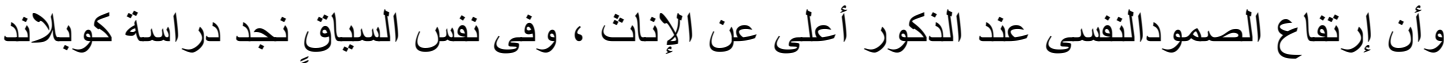
(Copeland, 2006)

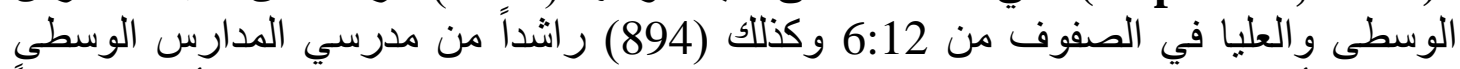

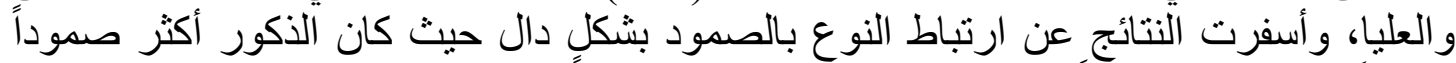

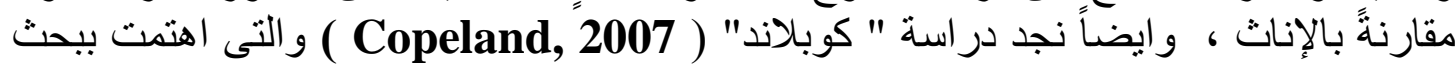

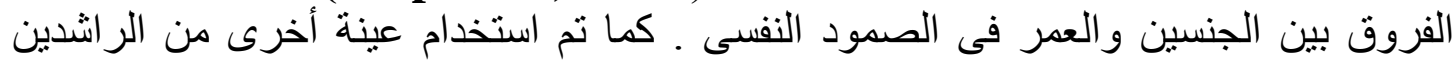

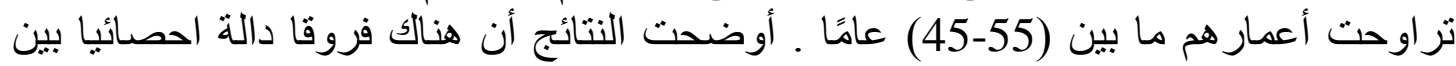

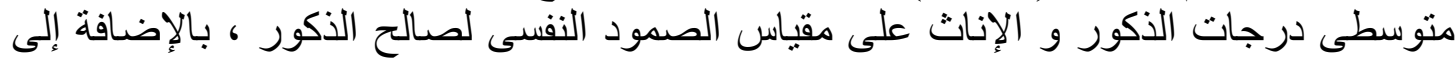

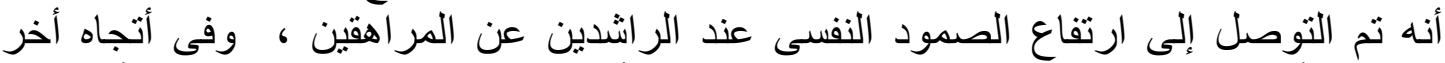

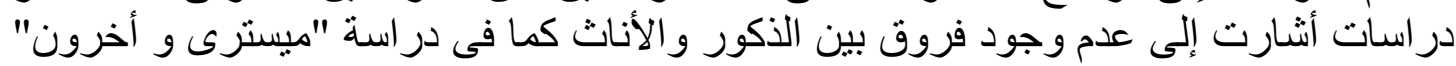
(Mistry et al. , 2009 )

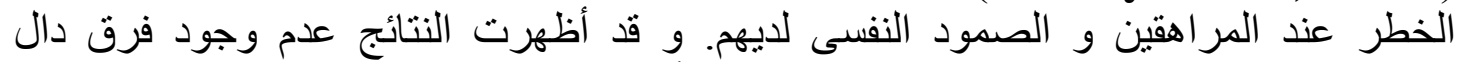
احصائيا بين متوسطى درجات الذكور و الإناث فى أبعاد الصمود النفسى ومكوناتة . لطائ.

وفى نفس السياق نجد در اسة ماندليكو (Mandleco, 1991) و أثنارت نتائجها إلى عدم وجود

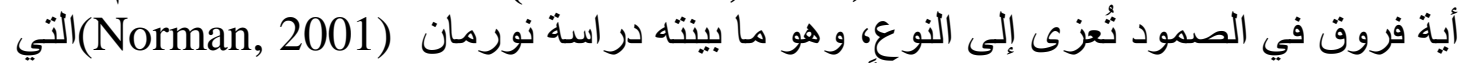

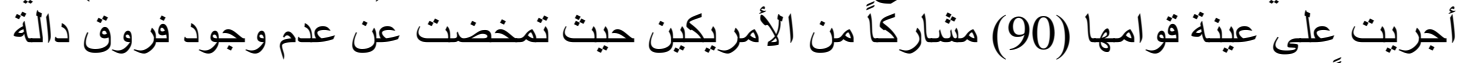

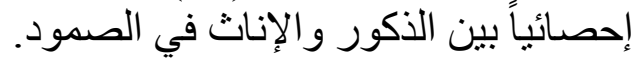
ب ـ تتباين كل من (الصمود و الأمل و التفاؤل) ومكوناتهما بتباين التخصص ( علمى - إدبى )،

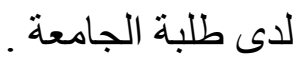
وللتحقق من هذا الفرض يمكن صياغتة بأسلوب إحصائى صفرى كالتالى : لا توجد فروق دالة التئ

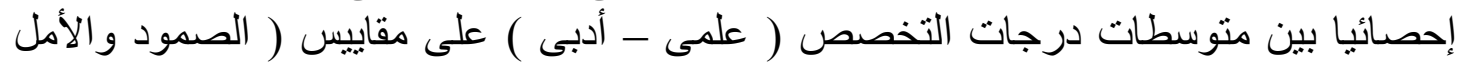

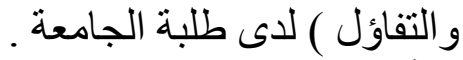

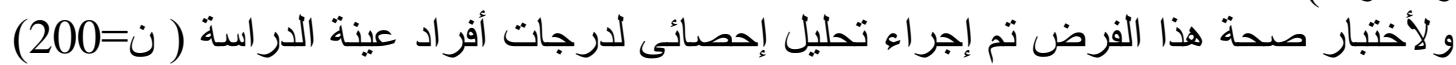

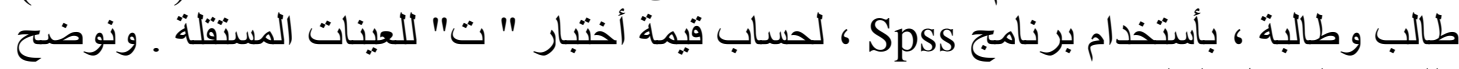
جدول ( 6) قيمة ( ت ) لدلالة الفروق بين ( علمى-ادبى ) على مقاييس

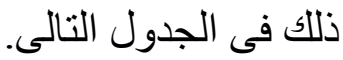
( الأمل ، التفاؤل ، الصمود النفسى ) لاى طلبة الجامعة (ن = 200 )

\begin{tabular}{|c|c|c|c|c|c|c|c|}
\hline مستوى الدلاية & "قيمة & الأنحراف & المتوسط & العدد & النوع & المكونات & \\
\hline
\end{tabular}




\begin{tabular}{|c|c|c|c|c|c|c|c|}
\hline \multirow[t]{2}{*}{ دالة } & 1.030 & 2.886 & 22.95 & 100 & أدبى & \multirow{2}{*}{ التوجة نحتبل } & \multirow[t]{2}{*}{ التفاؤل } \\
\hline & & 2.930 & 25.83 & 100 & علمى & & \\
\hline \multirow[t]{2}{*}{ دالة } & 1.077 & 2.506 & 22.00 & 100 & أدبى & \multirow{2}{*}{ الألرة على } & \\
\hline & & 2.745 & 25.15 & 100 & علمى & & \\
\hline \multirow[t]{3}{*}{ دالة } & 0.220 & 2.646 & 22.66 & 100 & أدبى & \multirow{3}{*}{ الرضا عن } & \\
\hline & & 2.928 & & 100 & & & \\
\hline & & & 23.28 & & & & \\
\hline \multirow[t]{2}{*}{ دالة } & 1.032 & 5.111 & 67.61 & 100 & أدبى & \multirow{2}{*}{ للأختبار الكلية } & \\
\hline & & 5.999 & 74.26 & 100 & علمى & & \\
\hline \multirow[t]{2}{*}{ دالة } & 0.000 & 2.180 & 20.99 & 100 & أدبى & \multirow[t]{2}{*}{ قوة الأرادة } & \multirow{6}{*}{ الأمل } \\
\hline & & 2.350 & 23.85 & 100 & & & \\
\hline \multirow[t]{2}{*}{ دالة } & 1.050 & 2.255 & 20.55 & 100 & أدبى & \multirow{2}{*}{ للإليجابية النظرة } & \\
\hline & & 2.899 & 23.99 & 100 & & & \\
\hline \multirow[t]{2}{*}{ دالة } & 0.700 & 2.000 & 21.74 & 100 & أدبى & \multirow{2}{*}{ تلأهقيق } & \\
\hline & & 2.180 & 23.05 & 100 & علمى & & \\
\hline \multirow[t]{2}{*}{ دالة } & 2.280 & 4.332 & 63.28 & 100 & أدبى & \multirow{2}{*}{ للأختبار الكلية } & \\
\hline & & 4.529 & 70.89 & 100 & علمى & & \\
\hline \multirow[t]{2}{*}{ دالة } & 2.588 & 2.220 & 22.05 & 100 & أدبى & \multirow{2}{*}{ الثخصية الكفاعة } & \multirow{6}{*}{ الصمود } \\
\hline & & 2.580 & 24.95 & 100 & & & \\
\hline \multirow[t]{2}{*}{ دالة } & 0.020 & 2.150 & 22.95 & 100 & أدبى & \multirow{2}{*}{ الإجثماعية الكفاعة } & \\
\hline & & 2.293 & 23.55 & 100 & & & \\
\hline \multirow[t]{2}{*}{ دالة } & 1.080 & 2.230 & 22.24 & 100 & أدبى & \multirow[b]{2}{*}{ الايجابي نحو } & \\
\hline & & 2.730 & 23.05 & 100 & علمى & & \\
\hline
\end{tabular}




\begin{tabular}{|c|c|c|c|c|c|c|}
\hline & & & & & & المستقبل \\
\hline \multirow[t]{2}{*}{ دالة } & 1.850 & 2.090 & 21.28 & 100 & أدبى & \multirow[t]{2}{*}{ المرونـه } \\
\hline & & 2.530 & 24.95 & 100 & علمى & \\
\hline \multirow[t]{2}{*}{ دالة } & 2.050 & 2.080 & 20.95 & 100 & أدبى & \multirow[t]{2}{*}{ الايمان } \\
\hline & & 2.450 & 21.85 & 100 & علمى & \\
\hline \multirow[t]{2}{*}{ دالة } & 2.900 & 5.703 & 109.47 & 100 & أدبى & \multirow{2}{*}{ للأخجتة الكلية } \\
\hline & & 5.423 & 118.35 & 100 & علمى & \\
\hline
\end{tabular}

يتضح من الجدول السابق أن قيمة " ت " لدلالة الفروق بين متوسطات أداء كل من ( أدبى -

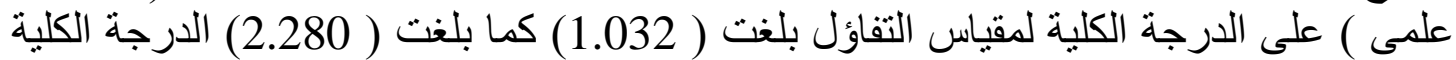
لمقياس الأمل ، وبلغت (2.900) للارجة الكلية لمقياس الصمود النفسى ، وجاءت كل القيات (لفيم دالة

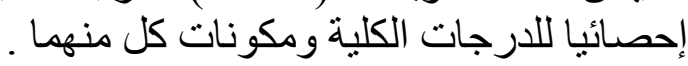

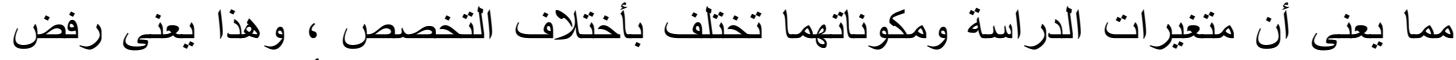

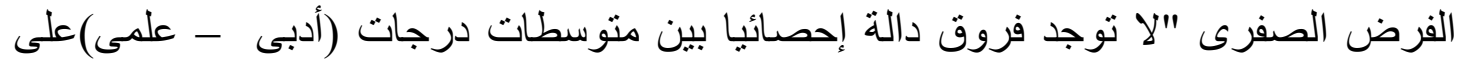

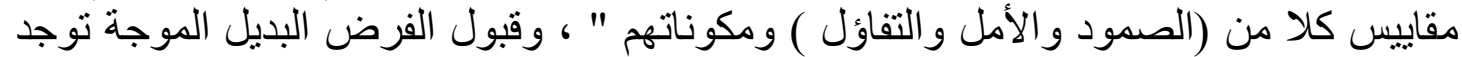

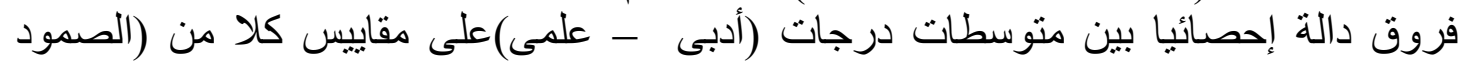

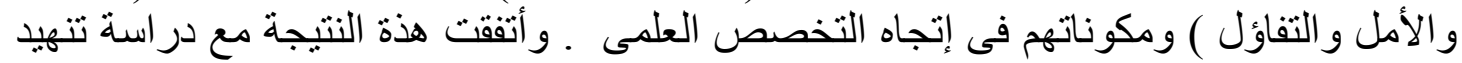

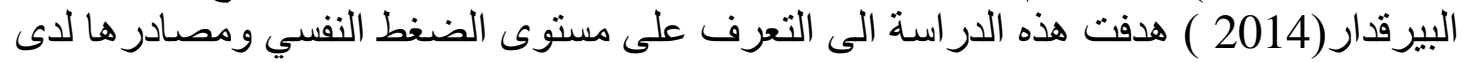

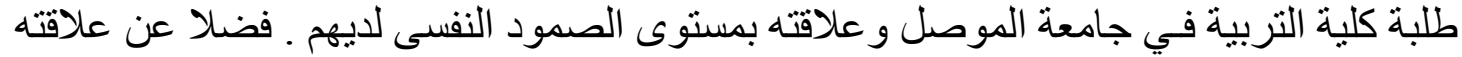

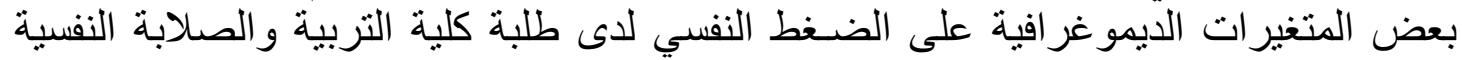

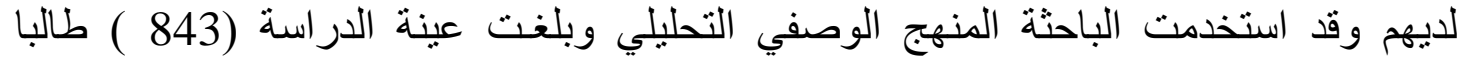

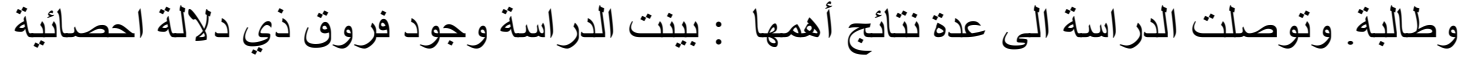

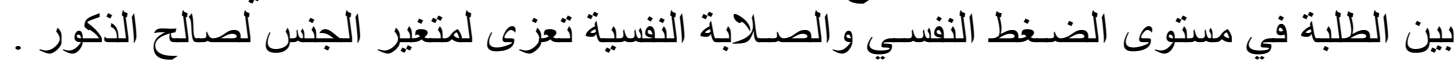

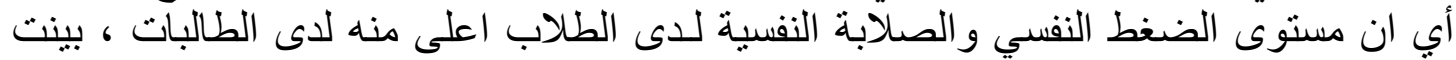

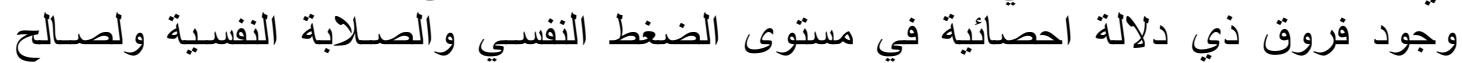
التخصص العلمي ، ودر اسة AL- Naser \& Sandman ( 2000) أكدت على أن أصحاب

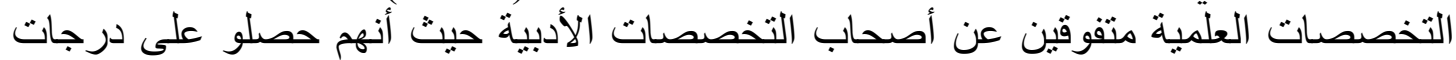

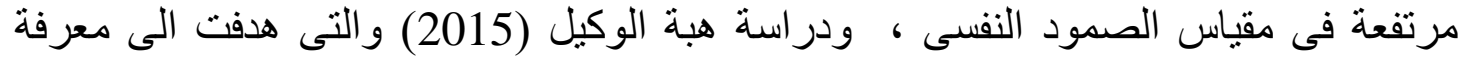

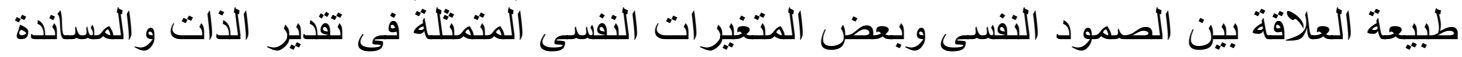

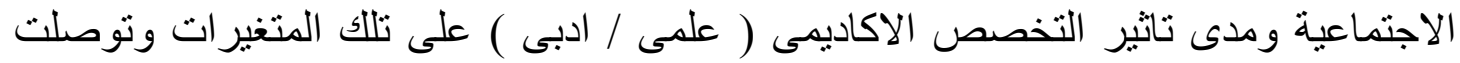

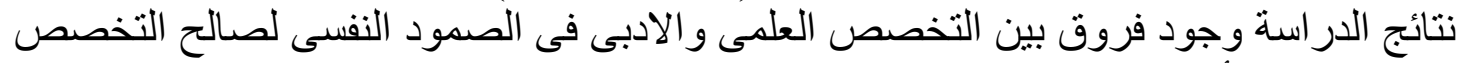

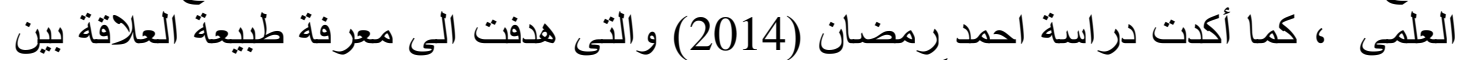

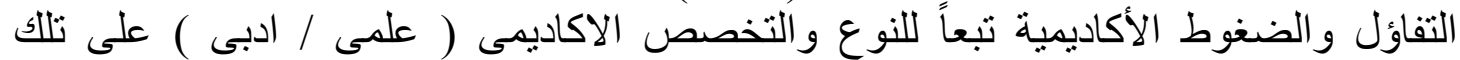

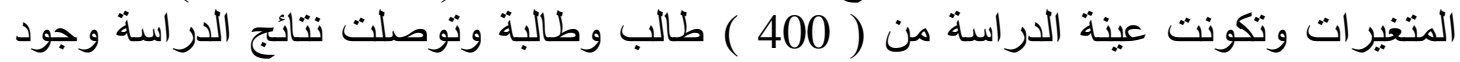

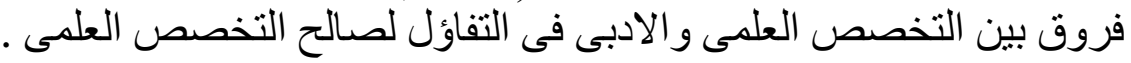




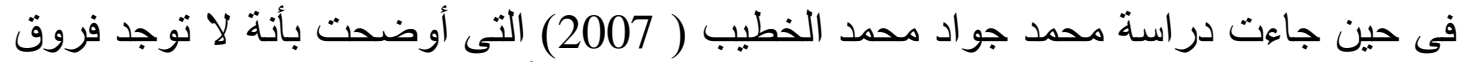

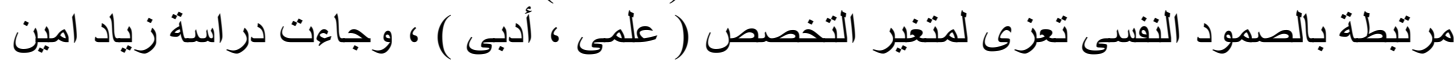

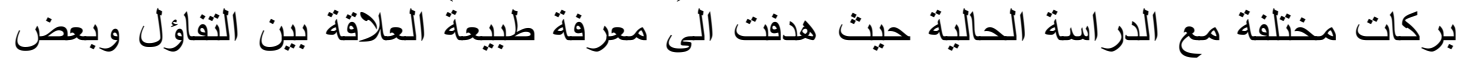

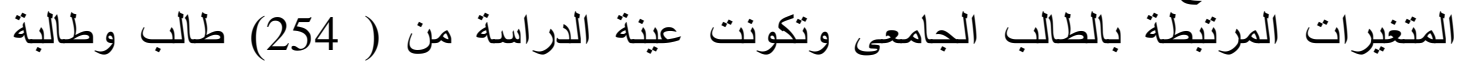
وتوصلت نتائج الدر اسة الى عدم وجود فروق بلج بين التخصص العلدى و الادبى فى التفاؤل.

وفى نفس السياق جاءت دراسة عفر اء ابر اهيم مختلفة مع الدراسة الحالية حيث هدفت الئ معرفة

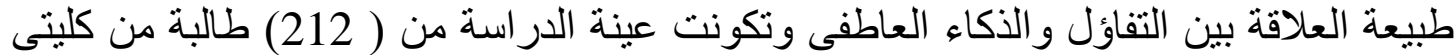

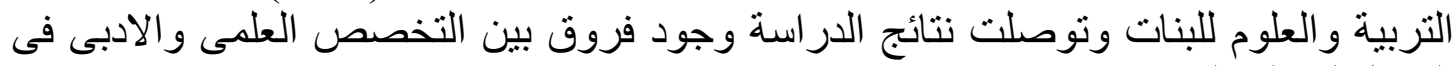

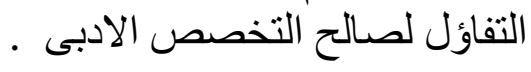

\section{بحوث مقترحة : نشير فيما يلى لبعض هذة الدراسات على النحو التالى :}

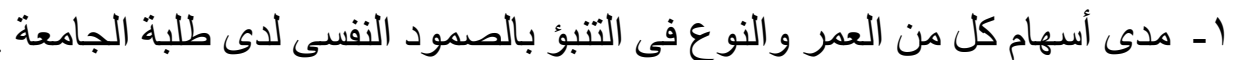

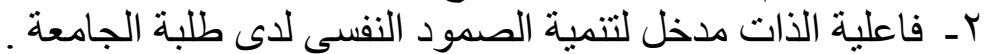

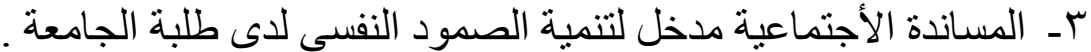

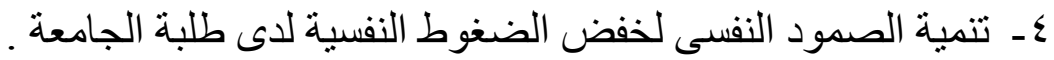
0ـ تنمية الصمود النفسى مدخل لخفض الضغوط الضغون الأكاديمية لدى طلبة الجامعة .

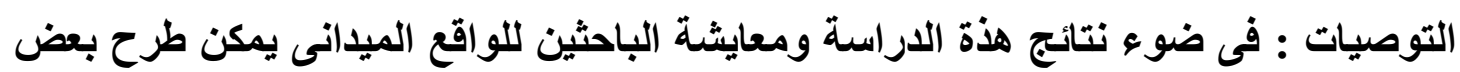
التوصيات على النحو التالى :

1 - ـ عقد ندوات علمية لأثر اء مقومات الصمود النفسى لطلبة الجامعة .

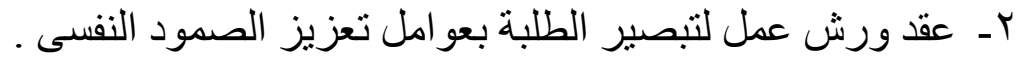

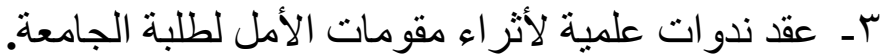

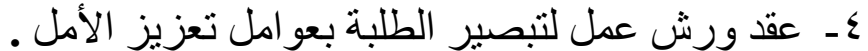

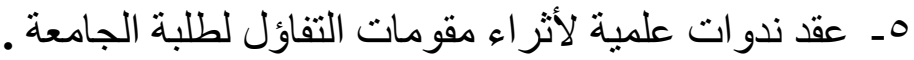

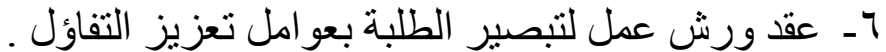

أحمد عبد الخالق ( 1998) ـ التفاؤل وصحة الجسم : دراسة عاملية ـ مجلة العلوم الأجتماعية ، 26( 2) ، 45-

أحمد محمد عبد الخالق ( 1999) ـ التفاؤل و التثاؤم : عرض لاراسات عربية ، مؤتمر الخدمة النفسية و التنمية ، جامعة الكويت : كلية الأداب ، قسم علم النفس ، 131- 152 .

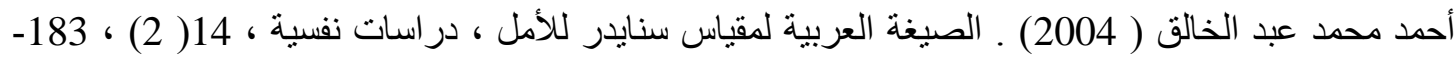

أحمد محمد عبد الخالق ( 2005) ـ المقياس العربى للتفاؤل و الثنشاؤم : نتائج مصرية ـ دراسات نفسية ، 15( 2) . $318-307$ ،

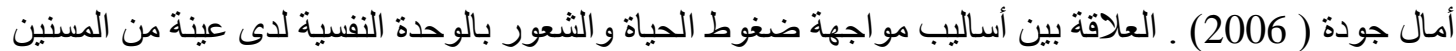
ـ مجلة جامعة القس المفتوحة للأبحاث و الدراسات ، 7 ، 65 - 108 ـ 108 ـ

ايمان مصطفى سبرمينى ( 2011) ـ ـتمية المهارات الأجتماعية لخفض الوحدة النفسية لدى مدمنى الأنترنت . رسالة ماجستير غير منشورة ، كلية البنات ، جامعة عين شمس .

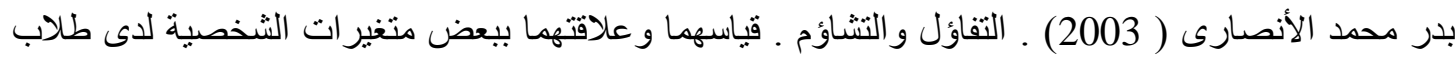

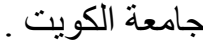


جولا ستين ، وبروكس ( 2010) ـ الصمود لدى الأطفال .( ترجمة صفاء الأعسر ، و إمام عبد الفتاح ) ـ القاهرة

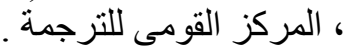

زيات بركات ( 1998) ـ سيكولوجية التفاؤل و التشاؤم و علاقتهما ببعض متغير العزير ات المرتبطة بالطالب الجامعى ،

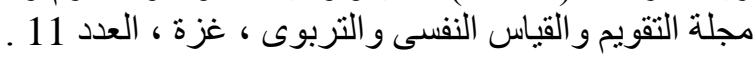

شوقى يوسف بهنام ( 2005) ـ قياس مستوى الأمل لدى عينة من طلبة كلية التربية ، مجلة شئون إجتماعية ، 87

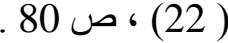

عبد الحميد جابر ، علاء الدين كفافى ( 1990) ـ معجم علم النفس و الطب النفسى ، (ج3) ـ القاهرة : دار النهضة العربية.

عبد الستار إبر اهيم ، عبداله عسكر ( 2005) ـ علم النفس الإكلينيكى فى ميدان الطب النفسى ، (ط 3 ) ـ القاهرة

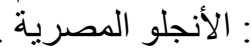

$$
\text { عبد اللطيف شرارة (1996) ـ تغلب على التشاؤم ، دار المؤلف ، بيروت . }
$$

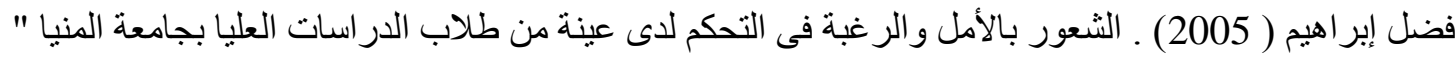

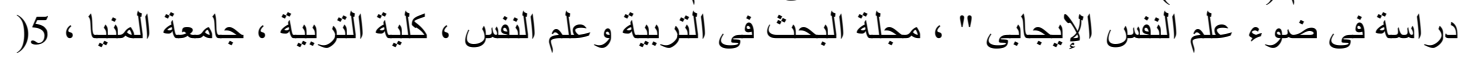

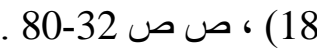

لولوة ، عبد اللطيف حسن ( 22003) ـ الصلابة النفسية والرغبة فى التحكم لدى طلاب الجامعة ، در اسات نفسية ،

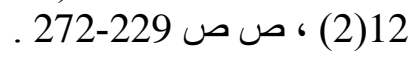

مايكل أرجايل ( 1993) ـ سيكولوجية السعادة ، ترجمة : فيصل يوسف ـ سلسلة عالم المعرفة ( 175) الكويت :

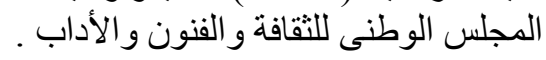

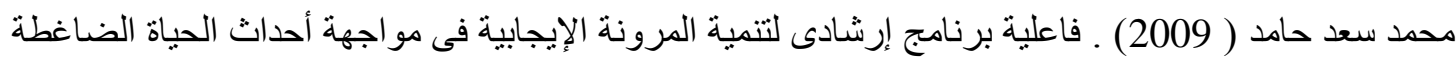

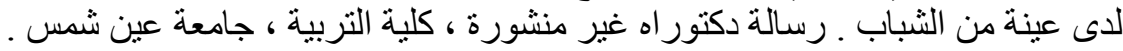
محمود عطية ( 2010) ـ ضغوط المر اهقين و الثباب وكيفية مواجهتها ـ القاهرة : الأنجلو المصرية . مجمع اللغة العربية ( 1972) ـ المعجم الوسيط ، ( ط3) ـ الجزء الأول .

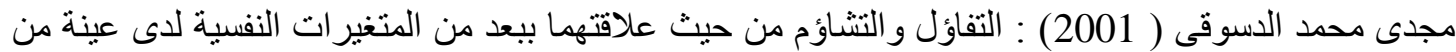

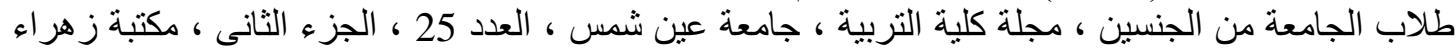

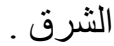

هبة حسين إسماعيل ( 2008) ـ تتمية التفاؤل والأمل مدخل لخفض الأعر اض الأكتئابية لدى عينة من ضعاف

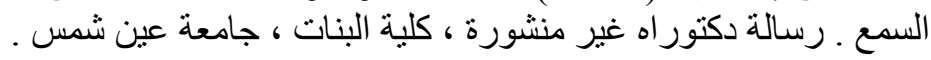

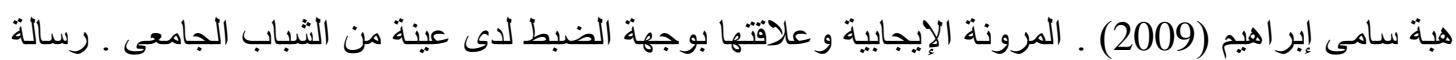
ماجستير غير منشورة ، كلية التربية ، جامعة عين شمس .

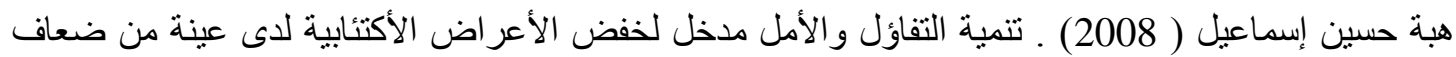

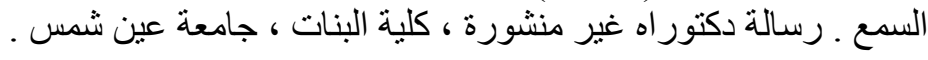

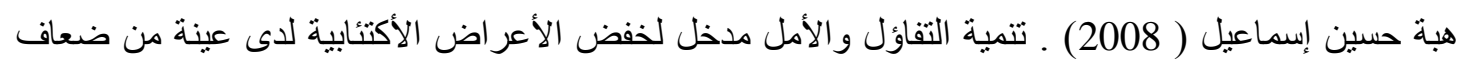

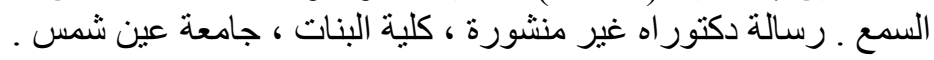

هيلة السليم ( 2006) ـ التفاؤل و التشاؤم و علاقتها بالعو امل الخمسة الكبرى للشخصية لاى عينة عينة من طالبات

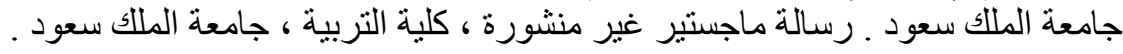
وئام على الثربينى ( 2007) . ديناميات الأمل لدى عينة من مريضات سرطان الثدى " دراسة نفسية تحليلية " .

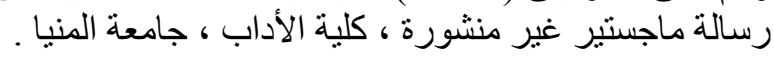

Anthony, D., Edwards, L. \& Bargeman, C. (2006). Hope as a source of resilience in later adulthood. Personality \& Individual Differences, 41(7), 1263 - 1273. 
Bailey, T., Eng, W., \& Frisch, M. (2007). Hope and optimism as related to life satisfaction. The Journal of Positive Psychology, 2(3), 168 - 175.

Brooks, J. (2006). Strengthening resilience in children \& youths: maximizing opportunities through the schools. Children \& Schools, 28(2), 69 - 76.

Carver, C. , Sheier, C. , Miller, M. \& Fulford, D. (2009). Optimism. In

Snyder, C. \& Lopez, S. Oxford handbook of positive psychology. Oxford University Press, 303- 312.

Carver, C. , Scheier, M. \& Segerstrom, S. (2010). Optimism. Clinical

Psychology Review. doi: 10. 1016/j. cpr.

Chang, E. , Olivares, A. \& D'Zurilla, T. (1997). Optimism and pessimism

as partially independent and negative affectivity and psychological well- being. Personality and Individual Differences, 23(3), 433- 440.

Collins, A. (2010). Life experiences \& resilience in college students: A

relationship influenced by hope \& mindfulness. Unpublished Ph. D. Texas A \& M University, United States.

Copeland, P. (2006). Factors related to resilience in teachers \& adolescents exposed to the Oklahoma city bombing. Unpublished Ph. D. Pepperdine University, United States.

Crawford, K. (2006). Risk \& protective factors related to resilience in adolescents in an alternative education program, Unpublished $\mathrm{Ph}$. D. University of South Florida, United States.

Daining, C. (2004). Resilience of African American youth in transition from out - ofhome care to adulthood. Unpublished Ph. D. University of Maryland, Baltimore.

Danet, J. \& Sean Cameron, J. (2003). Developing resilience in children who are in public care: The educational psychology perspective. Educational Psychology in Practice, 19(1), 3-19.

Egger, S. (1998). Optimism as a factor that promotes resilience in inner- city middle school students exposed to high levels of community violence. Unpublished $\mathrm{Ph}$. D. University of California, Los Angles, United States.

Gottschalk, L. (1985). Hope and other deterrents to illness. American Journal of Psychotherapy, 39(2), 779-780.

Jacobs, J. (2008). Resilience in emerging adulthood: academic success of postsecondary students raised in foster care. M. Ed. University of Alberta, (Canada).

Seligman, M. \& Csikszentmihalyi, M. (2000). Positive psychology: An

introduction The American Psychologist, 55(1), 5- 14.

Snyder,C.R.,(2002),Hope theory:Rainbow of the mind , Psychological Inquiry . 13, 249-275. 